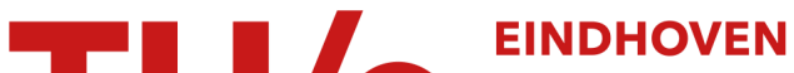 UNIVERSITY OF TECHNOLOGY
}

\section{Flat-plate PV-Thermal collectors and systems : a review}

Citation for published version (APA):

Zondag, H. A. (2008). Flat-plate PV-Thermal collectors and systems : a review. Renewable and Sustainable Energy Reviews, 12(4), 891-959. https://doi.org/10.1016/j.rser.2005.12.012

DOI:

10.1016/j.rser.2005.12.012

Document status and date:

Published: 01/01/2008

\section{Document Version:}

Publisher's PDF, also known as Version of Record (includes final page, issue and volume numbers)

\section{Please check the document version of this publication:}

- A submitted manuscript is the version of the article upon submission and before peer-review. There can be important differences between the submitted version and the official published version of record. People interested in the research are advised to contact the author for the final version of the publication, or visit the $\mathrm{DOI}$ to the publisher's website.

- The final author version and the galley proof are versions of the publication after peer review.

- The final published version features the final layout of the paper including the volume, issue and page numbers.

Link to publication

\section{General rights}

Copyright and moral rights for the publications made accessible in the public portal are retained by the authors and/or other copyright owners and it is a condition of accessing publications that users recognise and abide by the legal requirements associated with these rights.

- Users may download and print one copy of any publication from the public portal for the purpose of private study or research.

- You may not further distribute the material or use it for any profit-making activity or commercial gain

- You may freely distribute the URL identifying the publication in the public portal.

If the publication is distributed under the terms of Article 25fa of the Dutch Copyright Act, indicated by the "Taverne" license above, please follow below link for the End User Agreement:

www.tue.nl/taverne

Take down policy

If you believe that this document breaches copyright please contact us at:

openaccess@tue.nl

providing details and we will investigate your claim. 


\title{
Flat-plate PV-Thermal collectors and systems: A review
}

\author{
H.A. Zondag* \\ Energy Research Centre of the Netherlands (ECN), P.O. Box 1, 1755 ZG, Petten, The Netherlands
}

Received 11 November 2005; accepted 16 December 2005

\begin{abstract}
Over the last 30 years, a large amount of research on PV-Thermal (PVT) collectors has been carried out. An overview of this research is presented, both in terms of an historic overview of research projects and in the form of a thematic overview, addressing the different research issues for PVT.
\end{abstract}

(C) 2007 Elsevier Ltd. All rights reserved.

Keywords: PVT; Ventilated PV; BIPV; Hybrid; PV; Thermal

\section{Contents}

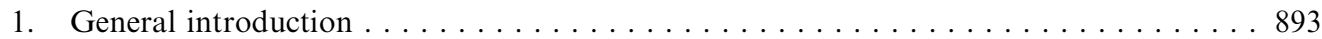

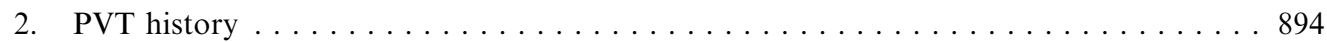

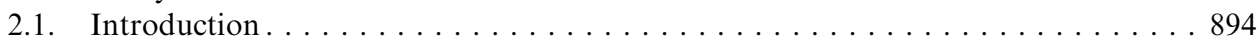

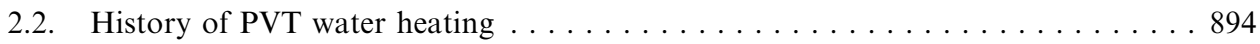

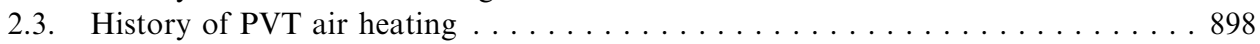

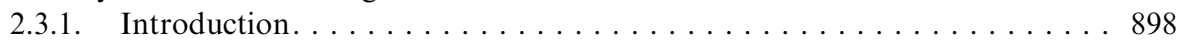

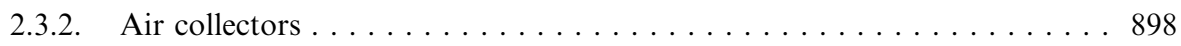

2.3.3. Ventilated PV with heat recovery . . . . . . . . . . . . . . . . . 899

*Tel.: + 31224 564941; fax: + 31224568966 .

E-mail address: zondag@ecn.nl. 


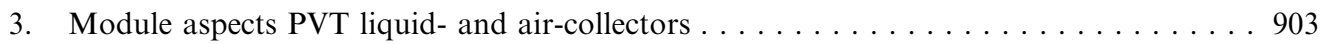

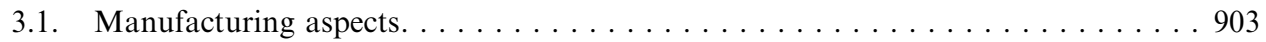

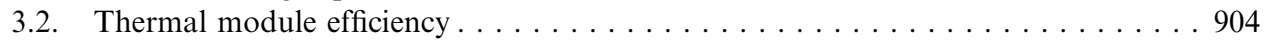

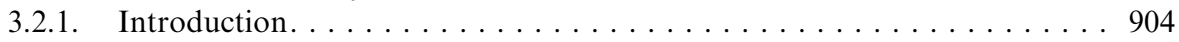

3.2.2. Reflection losses . . . . . . . . . . . . . . . . . . . 907

3.2.3. Thermal resistance . . . . . . . . . . . . . . . . . . . 913

3.2.4. Thermal losses . . . . . . . . . . . . . . . . . . . . . . . 920

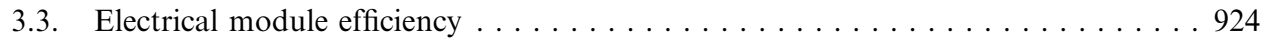

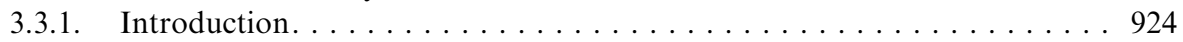

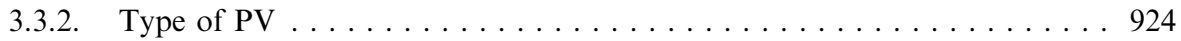

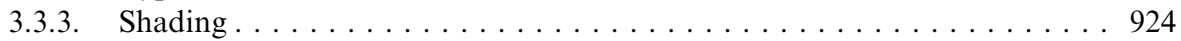

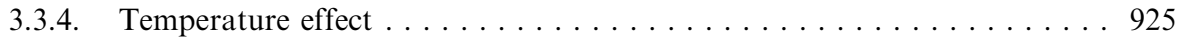

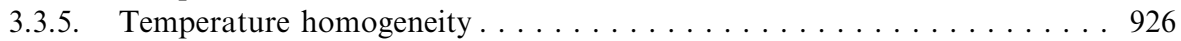

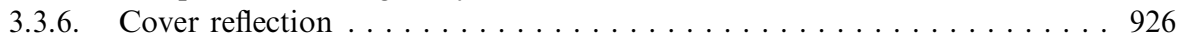

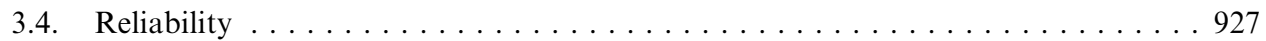

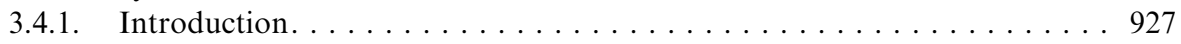

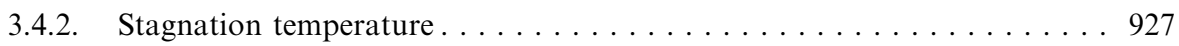

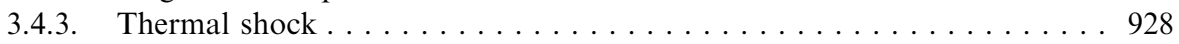

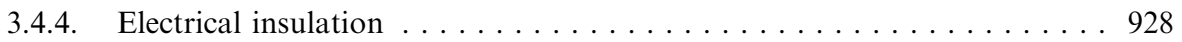

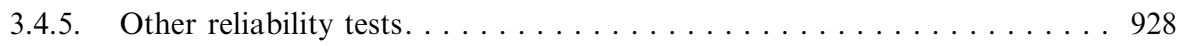

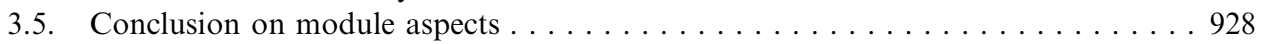

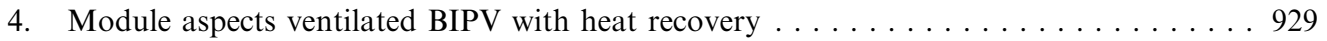

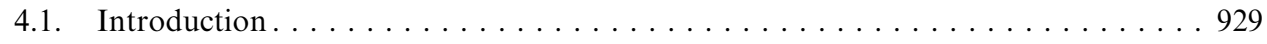

4.2. Thermal efficiency. . . . . . . . . . . . . . . . . . . . . . 929

4.2.1. Natural convection . . . . . . . . . . . . . . . . . . . . . . . . 929

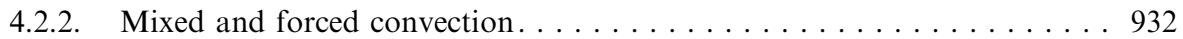

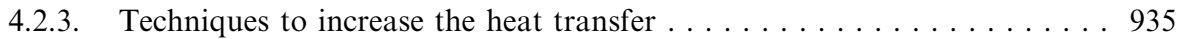

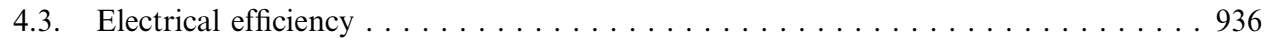

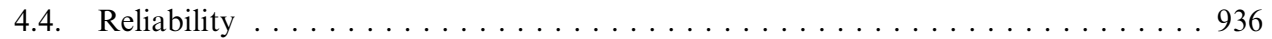

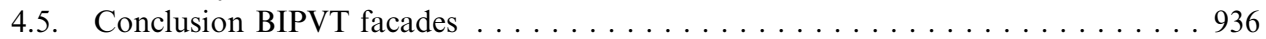

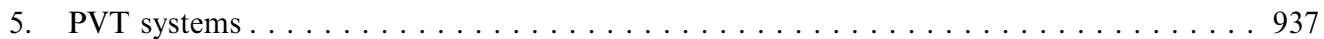

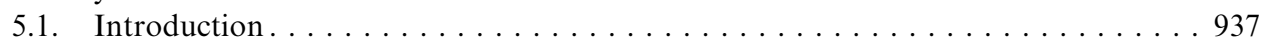

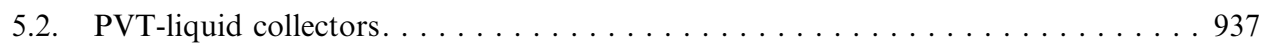

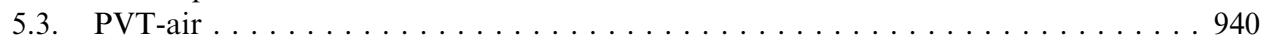

5.3.1. Introduction. . . . . . . . . . . . . . . . . . . . . 940

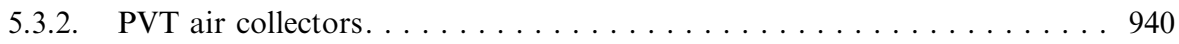

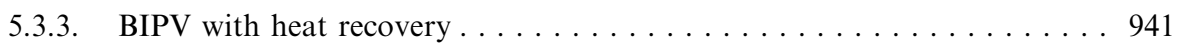

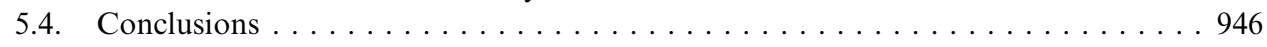

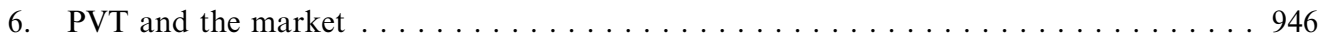

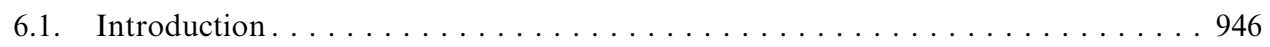

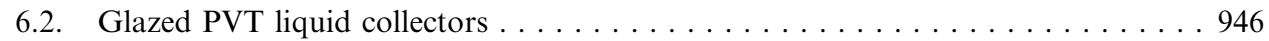

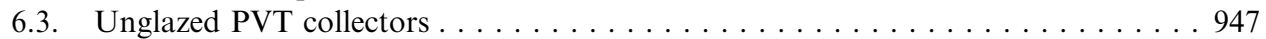

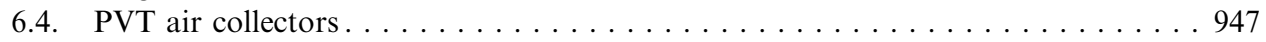

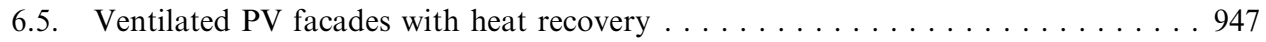

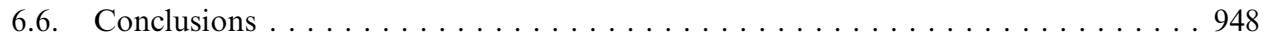

References . . . . . . . . . . . . . . . . . . . . . . . . . . . 949 


\section{General introduction}

A PV-Thermal (PVT) collector is a module in which the PV is not only producing electricity but also serves as a thermal absorber. In this way, heat and power are produced simultaneously. Since the demand for solar heat and solar electricity are often supplementary, it seems a logical idea to develop a device that can comply with both demands.

Over the years, a large amount of PVT research has been carried out, originating from several independent developments that all resulted in the idea of integrating PV and thermal into one module. The main developments were as follows:

\section{Grid-connected applications:}

(a) The research on PVT started during the mid-1970s, with the focus on PVT collectors, with the main aim of increasing the energy efficiency. Domestic application was regarded as the main market. Initially the focus was on glazed collectors, both air-type and liquid-type, but soon the idea of an unglazed PVT collector combined with a heat pump also received attention.

(b) In the beginning of the 1990s, large PV facades started to receive attention and the issue of ventilating these in order to reduce the PV temperature, quickly lead to the idea that this heat could also be used, e.g. for room heating.

\section{Autonomous systems:}

(a) Small air collectors for autonomous applications, in which the fan could be driven by PV, were developed for markets such as the ventilation of cottages. For this market, PV-air collectors with a little PV have been developed.

(b) Research was carried out on PVT liquid collectors for autonomous application in developing countries, with specific attention for the ratio of thermal yield over electrical yield.

\section{Concentrator PV:}

(a) Research on concentrating PV was based on the idea of replacing expensive PV by cheap reflectors. A point of attention was the high temperature that could be reached by the cells. Therefore, cooling of the cells was necessary. By using active cooling the heat could be used as well.

In the present paper, the emphasis will be on topic 1 . This choice was made because gridconnected, building-integrated applications are seen as the main future market for PVT systems. The literature on autonomous systems and concentrator systems will only be taken into account insofar as topics are addressed that are also of importance for gridconnected flat-plate building-integrated systems. For the work on PVT concentrators, the reader is referred to, among others, the work carried out at the Lund University, the Australian National University and the University of Lleida (e.g. [1-3]). In addition, the choice was made not to discuss LCA aspects for PVT in this review. For this subject, the reader is referred to the work of Frankl and Battisti at the University of Rome (e.g. [4,284,6,295] and the work of Crawford et al. [7]). Finally, the issue of combining electrical and thermal yield into an overall efficiency for PVT is not discussed here; for a nice overview the reader is referred to the work of Coventry [8]. 
Over the years, a number of inventories have been made of PVT research and products, such as presented in the work by Leenders et al. [9], Soerensen and Munro [10], Meyer [11], Bazilian et al. [72,210], the report on the IEA PVPS task 7 workpackage 2.5 on PVT collectors [13], Bosanac et al. [14], Charalambous et al. [15,16] and the PVT roadmap [17]. The literature referred to in these overviews has been re-examined critically and has been expanded substantially. In addition, the results are presented in the form of an historical and a thematic overview, to present the mass of results in a clear and comprehensive way.

Although an attempt has been made to be as complete as possible, it is inevitable that some of the relevant research is missed in this compilation. If this has occasionally happened, it was not intentional and the author apologises beforehand to anyone who feels that his work is not done the credit it deserves. In addition, a significant part of the work on PVT will not be in this review because it has been carried out within companies and is classified as confidential and has therefore not appeared in the open literature.

\section{PVT history}

\subsection{Introduction}

Solar thermal collectors have a long history and have been in commercial production since the 19th century, whereas the commercial production history of the PV cell dates from the 1950s. During the 1960s solar cells were still very expensive and R\&D concentrated on the space industry. However, after the OPEC oil embargo in 1973/1974, resulting in a massive increase in the oil price, research into renewable energy was strongly stimulated by many governments. This stimulated research into the application of techniques that were previously considered as too expensive. Among these techniques was the terrestrial application of solar cells, and along with this also the first PVT projects were launched.

\subsection{History of PVT water heating}

As indicated by Hendrie [18], the first work on flat-plate PVT-liquid seems to have been the work of Martin Wolf [19], who analysed a silicon solar array mounted inside a stationary non-concentrating thermal collector, using a lead-acid battery as the storage element for residential heating. He concluded that the system was technically feasible and cost effective. The research on PVT-liquid was continued at various groups, such as MIT. A first demonstration project was realised by Professor Böer, who applied 13 PVT-liquid collectors at his own home 'Solar Knoll' in about 1978. After the pioneering study of Martin Wolf in 1976, the subject of PVT liquid was quickly taken on by other groups. During 1974-1978, research on PV concentrators was carried out at the Arizona State University, including actively cooled PVT concentrators [20], with the focus on modelling for TRNSYS-application. This work was extended to include PVT flat-plate collectors as well [20-22] and was the basis for the PVT model TYPE 50 that is presently available in TRNSYS. In 1978, MIT Lincoln laboratory and Sandia jointly acquired three full-size flat-plate prototype PVT collectors [18]. These collectors were manufactured by ARCO (both an air-type and a liquid-type) and Spectrolab (air-type). In the subsequent testing of these collectors at MIT, the performance of these collectors turned out to be below the initial specifications of $6.5 \%$ electrical and $40 \%$ thermal efficiency. Therefore, a second 
generation of PVT collectors was developed, consisting of two production-ready PVT liquid designs, two experimental advanced PVT air designs and three new PVT liquid concepts (a dual flow concept, an advanced unglazed concept and a two-phase Freon concept in which the PVT functioned as the evaporator of a heat pump). Of the two production ready designs, one was developed by MIT and the PV-manufacturer Spire Corporation (a concept for mounting on top of an existing roof) and the other by Solar Design Associates and Spire Corporation under the auspices of MIT (a roof-integrated collector replacing roofing material). However, not all concepts could be built due to the termination of the funding program. The results of the work have been published in a number of papers and a final report [18,23-26]. Also research on PVT systems was carried out at MIT [27-29]. At Sandia, research was carried out into the effect of thermal gradient on the electrical performance $[111,241]$. In 1980 PVT research was started at JPL and Brookhaven laboratories [30,31].

Whereas most of the research was going on in the USA, also some activities were carried out in Japan, where Sharp manufactured two flat-plate PVT prototypes [32], while also work on concentrating PVT was carried out by Nakata et al. [289] at Sharp Corporation. In Germany, Karl [33] developed and tested a glazed c-Si prototype (together with AEGTelefunken) and in France, studies on concentrating PVT were carried out [288,286]. However, in the rest of the world, no PVT activities seem to have taken place at that time.

However, in 1982 the oil price collapsed, which eroded the feeling of urgency regarding the development of solar energy. At the beginning of the Reagan years (1981-1989), funding for renewable energy was seriously restricted in the USA. This lead to the termination of most projects in this field. During the 1980s research on PVT collectors was limited. Most research groups stopped working on PVT, but some continued. In the USA, SunWatt did work on low-concentrating stationary PVT modules [34,35,242,219]. Starting the development in 1978, SunWatt manufactured and installed over 100 PVT-liquid collectors during the period of 1981-1989. Also during the 1980s, a few scattered projects were carried out in Europe: research was carried out in Switzerland at the Institut de Microtechnique de l' Université de Neuchâtel [36,37] and in Yugoslavia [38,39].

In the 1990s there was again an increasing interest for renewable energy, among which PVT, especially in Europe. An important factor in this was the influence of the Brundtland Report (1987). Also the issue of global warming gained increasing political recognition (UNCED conference in Rio de Janeiro, 1992).

In the Netherlands, research on PVT started in 1989 at TNO, in cooperation with HES, where also the focus was on uncovered PVT for heat pump applications [40,41]. However, this work stopped in 1996. Next, the Eindhoven University of Technology (EUT) started a PhD project during 1994-1998 [42-46], which focussed on covered PVT modules for DHW applications. In 1999, Ecofys, TNO and the EUT jointly carried out a technology- and market review for PVT [9,47]. In 1999, the PVT research at the EUT was transferred to the Energy Research Centre of the Netherlands (ECN). ECN carried out a large amount of module design studies [48,49,51,52] and systems studies [53-58,271,285] for PVT. In addition, together with Shell Solar and ZEN Solar, PVT collectors were developed and manufactured for a $54 \mathrm{~m}^{2}$ PVT array that was part of the zero-emissions headquarter of Renewable Energy Systems [60]. The building project as a whole was funded within EU FP 5 during 2000-2004 and project partners were Studio E Architects, ECN, Shell Solar, Esbensen Consulting Engineers, Dewhurst Macfarlane, Max Fordham and Renewable Energy Systems Ltd. During 2003-2005 the PV-Catapult project was carried out within 
EU FP 6, coordinated by ECN, with participation of Arsenal Research, Ecofys, Esbensen Consulting Engineers, Fraunhofer ISE, ISFH, Solstis and the University of Patras, resulting in a roadmap for PVT [17, 59] and a guideline for PVT performance testing [61]. During 2004-2008, a Ph.D. project on optical modelling of PVT was carried out by Santbergen at the EUT, supported by ECN [226,227].

In Germany, the manufacturers Zenith, Solarwerk [62,282] and Solarwatt developed prototype PVT collectors during the $1990 \mathrm{~s}$, but unfortunately this did not lead to commercial available collectors. Solarwatt PVT collectors were planned to be installed in a demonstration project at the Malteser Krankenhaus, but instead of the PVT, it was decided to use conventional collectors. Although the company Solarwerk was taken over by Solon, the PVT development was continued, but in contrast to the glazed Solarwerk concept, the Solon PVT development focuses on unglazed PVT modules. Research on PVT connected to a flat metal PCM heat storage tank was carried out at the Cottbus University, but the use of the PCMs lead to many problems [63]. Finally, initially in Germany and presently in Brazil, from 1992 onwards Stefan Krauter has been working on PVT-ICS systems, in which a PV laminate is connected to a triangular water storage [64-67].

In Denmark, a PVT research project was carried out involving the solar collector manufacturer Batec, the PV-company Racell and Esbensen Consulting engineers. In 2000, PVT collectors were tested and installed. However, due to the collapse of the Danish Renewable energy market, Batec decided to end its involvement with this development, but Racell continued its efforts in this field. Also, within the framework of the EFP programme, the Danish Technological Institute, Esbensen and Novator Consulting did a systems and literature study on the potential of PVT collectors in Denmark $[14,68,69]$. Furthermore, in a workshop on PVT in 1999 in Amersfoort, the Netherlands, organised by the Utrecht Centre for Energy research (UCE), it was agreed to start preparations for an IEA joint working group on PVT, with participation of both SHC and PVPS. The joint working group was accepted by the IEA and was lead by Esbensen Consulting in Denmark. Other parties actively involved in this IEA project were the UNSW and Ecofys. The project resulted in two meetings on PVT (Copenhagen 2000 and Rapperswill, 2000), PVT projects and technology overviews [10,12] and a roadmap [73]. The work of the joint working group was continued within IEA PVPS task 7 activity 2.5, resulting in the IEA report Photovoltaics/thermal Solar Energy systems [13]. In 2004, the present IEA SHC task 35 on PVT systems was started, with Esbensen Consulting as operating agent (www.pv-t.org).

A large amount of PVT module research was carried out at the University of Patras, involving comparative experimental studies on glazed and unglazed PVT collectors, with and without booster reflectors $[5,75,77,79]$. Also an economic study was carried out [80]. In Cyprus, a numerical study was carried out for a thermosyphon PVT system, [81] and a literature review was presented [15,16]. Further work on the modelling of PVT thermosyphon studies was carried out in cooperation with the University of Patras [82,294]. LCA work on PVT has been carried out at the University of Rome by Frankl and Battisti [4]. These studies were later continued in cooperation with the University of Patras [6,284].

At the University of Oslo, an analytical design study was carried out [83] and, together with SolarNor, a study on a polymer-based PVT Collector [84-86]. In Switzerland, in a project with the University of Neuchatel and Ernst Schweizer AG, research was carried out on optical characterisation of PV for PVT applications by Platz [229] and in a project with 
EPFL, Enecolo and Ernst Schweizer AG a PVT technology overview and an optical study were carried out by Affolter [220,228,280,281]. For Corsica, a systems study for an unglazed PVT was carried out by Mattei et al. [278]. In Hungary, an unglazed PVT was built by the Technical University of Budapest and SOLART Systems Ltd., using an extruded aluminium sheet-and-tube profile and an absorbing encapsulant layer below the PV [269].

In Israel, a commercial unglazed PVT collector was developed. The emphasis in this development was originally to reduce the overheating of $\mathrm{PV}$ that is a severe problem in the Israeli deserts. In the winter 1991/1992 a PVT system was installed in Klil, a small village in Israel. In 1996, a US patent was granted [87]. The PVT collector was initially produced by Chromagen, but since 2002 the production went over to Millennium Electric. In addition, Millennium Electric has licensed the production of its PVT-system to others (Photon International, June 2004). In 2004 Millennium Electric has started the EU supported MULTISOLAR project (with e.g. the Technical University of Denmark) to develop building-integrated PVT products for the European market.

In Japan, several studies were carried out, such as a PVT demonstration project [88], a PVT module study [89] and studies for PVT as source for a heat pump [90-92,253]. Huang et al. $[93,94]$ did a study on unglazed PVT at the National University of Taiwan. At the City University of Hong Kong, Chow [95,233] built a dynamical model for a PVT collector, which was used to calculate the performance of a thermosyphon system. At the University of Science and Technology of China, in cooperation with Chow, Ji et al. [234,215,96] carried out a sensitivity study for this system and He et al. [97] describe experimental results. In India, the focus was on stand-alone thermosyphon applications for PVT, that were largely carried out at the Centre of Energy Studies of the Indian Institute of Technology in New Delhi and at the University of Delhi [98-100,230,235,129]. In Thailand, the National Science and Technology Development Agency developed PVT collectors with amorphous silicon (a-Si) connected to the surface. Three types of glazed prototypes were tested, consisting of a-Si deposited on stainless steel or glass and connected by means of a conductive epoxy to aluminium absorbers with copper tubing [101,102]. Since then, four large pilot PVT systems were installed at government buildings in Thailand; at NSTDA $\left(40.6 \mathrm{~m}^{2}\right.$; for cooking and dish washing), Banglamung hospital $\left(48 \mathrm{~m}^{2}\right.$, for clothes washing), Military police 11 in Bangkok $\left(48 \mathrm{~m}^{2}\right.$, for cooking and dish washing) and Sirikit hospital $\left(152 \mathrm{~m}^{2}\right.$ for the hydrotherapy swimming pool). More are indicated to follow [103,104]. In Brazil, Krauter did measurements on an unglazed PV facade with an integrated propylene cooling system, with the aim of both PV cooling and water heating [273-275].

In the USA, recent work was carried out within the PV:BONUS program [117]. PVT projects were carried out by PowerLight and SDA. The PowerLight development focussed on uncovered flexible PVT modules, based on steel-substrate a-Si cells on swimming pool collectors. However, problems related to manufacturing cost and product reliability led to the decision not to manufacture the PVT [105]. The SDA Project (1997-2001) focussed on the development of a glazed PVT collector based on the United Solar a-Si laminate and the SunEarth collector, to be installed at the Montana State University. However, the manufacturing tolerances in the absorber production caused problems for the PV integration. Commercial production of the PVT was not started because the required initial investments in equipment were too large to be justified by the expected profit [106]. 


\subsection{History of PVT air heating}

\subsubsection{Introduction}

Within the topic of PV-air, two different subjects come together:

- PV integrated in air collectors: This research often starts with the idea of an air collector that can run without access to the grid, with the additional benefit of having an irradiance-controlled mass flow. Autonomous PV-air collectors have been developed in this way by Grammer Solar and Aidt Miljø [14,17]. However, research institutes and commercial companies have extended this idea to PVT-air collectors with PV over the entire absorber.

- Ventilation of BIPV: Whereas the initial question was how to cool the PV, this research naturally lead to the question how much heat was produced and how it could be applied.

\subsubsection{Air collectors}

It seems that the first PVT-air facility was the 'Solar One' house, that was built in 1973/ 1974 at the University of Delaware by Professor Böer [107], who by that time had done a large amount of work on PV. In the roof and façade of this house, air collectors were integrated, and four of the 24 roof collectors were equipped with $\mathrm{CdS} / \mathrm{Cu}_{2} \mathrm{~S}$ cells [108]. ${ }^{1}$

After the pioneering work of professor Böer, in the late 1970s and early 1980s the main research in PVT air was carried out in the group of Hendrie $[18,24,26,109]$ and also at Sandia and Brown University. As indicated before, in 1978 MIT Lincoln laboratory and Sandia laboratories acquired jointly two full-size flat-plate prototype PVT air collectors manufactured by ARCO and Spectrolab [18] and the insufficient performance of this first generation of PVT collectors motivated the development of a second generation, for which a number of novel concepts were developed at MIT, but unfortunately not all concepts could be tested due to termination of the funding. At Sandia, research was carried out into the effect of thermal gradient on the electrical performance [111]. At the Brown University, in 1982 a building was realised with a $33.5 \mathrm{~m}^{2}$ PVT-air collector $[110,112]$. However, the financing stopped before the building could be taken into use [11].

Similar to the case of PVT liquid, also for PVT air little work was carried out during the mid and late 1980s. An exception is presented by Komp and Reeser [113], reporting on a concentrating glazed PV-air collector system. Only in the early 1990s did the number of publications rise again.

In Japan, Ito and Miura [114] did measurements on partially transparent photovoltaic modules as the top cover of an unglazed air collector. This design was chosen over the design in which the air was flowing between the PV and the top cover, because of the higher PV temperatures involved in the latter design. Thermal efficiencies were found in the order of $40 \%$, strongly depending on the wind speed. In 1994, the Capthel collector, a PV-air collector, was developed by the French Company Cythelia [115]. Also in the early

\footnotetext{
${ }^{1}$ Hendrie [18] argues that this system was actually a side-by-side system designed to simulate a combined PVT array. However, this may be a mistake since Malik [108] in his description of the 'Solar One' explicitly states that "four of the roof collectors are equipped with $\mathrm{CdS} / \mathrm{Cu}_{2} \mathrm{~S}$ cells of different origin and make, and are connected to the heat-collecting substrate by different means". Either way, it can be concluded that this was the first system to explore the PVT air concept.
} 
1990s, in Israel, an unglazed PVT collector was developed and commercialised with both liquid and air heat extraction [87]. However, the main purpose of the hot air option is to provide additional cooling of the PV.

The German Company Grammer Solar and the Danish company Aidt Miljø have both developed a PVT-air collector with a small PV-fraction [14,17]. In this type only a small part of the absorber is covered with $\mathrm{PV}$, in order to drive the fan, and is mainly used for autonomous application in vacation cottages for dehumidification purposes. In addition, Grammer Solar has also developed and commercialised a PVT-air collector in which the absorber is fully covered with PV. The first demonstration project with this collector was realised in 1996 (preheating of ventilation air for a painting facility in Nürnberg) and a number of other projects has been realised since.

In Canada, Conserval Engineering developed the PV SOLARWALL system with Bechtel and CANMET. Experimental research on prototype PV-Solarwall modules was carried out, including thermal performance measurement and flashtesting for electrical performance [116]. A number of systems has been installed. In the first phase of the PV:BONUS 2 program, Energy Conversion Devices Inc., together with several other partners started the development of a concept in which the flexible a-Si laminates of United Solar are integrated into the Solarwall collector of Conserval Engineering [9,117]. However, the project was terminated prematurely when it was decided that Solarwall as a Canadian company could not apply for PV:BONUS grants. In a cooperation with KIER, an evaluation of the perforated collector with c-Si PV is presented by Naveed et al. [240].

At the University of Patras, research was done on an unglazed PVT collector with both liquid and air heat extraction [77]. The optimal performance was found to be with the PV in direct contact with the sheet-and-tube absorber, while an airflow through the air spacing underneath the sheet-and-tube absorber could provide air heating as well. Furthermore, the thermal optimisation of a PVT air collector by locating a thin metal sheet in the air channel was studied both experimentally [76,78,178,249,295] and numerically [118].

In the USA, at the University of Miami, PhD research on double pass PVT air collectors was carried out by Sopian [119,120], who continued this work at the Universiti Kebangsaan Malaysia [121]. In addition, he investigated a low-concentrating double pass PV-air collector [122]. In Egypt, a simulation study comparing several PVT-air collector designs was carried out by Hegazy [123], in which the efficiency of the double pass collector was underscored.

In India, research was carried out at the Indian Institute of Technology on PVT air heaters for solar drying [124-128]. In addition, a parametric study for glazed and unglazed PVT air-collectors was carried out by Tiwari and Sodha [130], who found that the glazing almost doubled the useful thermal output, while the electrical efficiency dropped from $10 \%$ to $9 \%$ due to the glazing, while Prakash [235] did a numerical sensitivity study on the effects of duct depth and flow rate in a PVT collector.

\subsubsection{Ventilated $P V$ with heat recovery}

In the early 1990s, BIPV started to become more important. In the monitoring of these projects, it became apparent that the technique applied for building integration affected the temperature of the cells and thereby the electrical performance. This lead to increased attention for the ventilation of PV-facades. A natural next step was research on how this heat could be applied.

In Europe, several PVT-air projects were carried out in Switzerland by Atlantis Energy, such as PVT air roof in the Aerni factory in 1991, the PVT-air façade system at the 
Scheidegger building in 1992, the PVT-air roofs Brig and Rigi in 1993 and the PV-air system system for hot water generation at the Erlach school building [131-134]. The PVTroof projects (Erlach, Brig and Rigi) were all PV-shingle roofs. Then Atlantis Energy introduced the PV SUNSLATES ${ }^{\mathrm{TM}}$ concept, for which Posnansky et al. [135] indicate the possibility of cogenerating both electricity and heat. A test-roof made of Sunslates was tested within the EU project PV-HYBRID-PAS [296]; it was concluded that airtightness of the roof is crucial for the thermal performance. This was followed by a project on PVT-air involving the Eidgenössische Technische Hochschule Zürich (ETH) and the Hochschule für Technik und Architektur Luzern (HTA), studying the thermal energy yielded by a PVT-slate for roofs developed by Atlantis energy [136,137]. Unfortunately, these developments ended with the collapse of Atlantis Energy Investments and its subsidiaries in 2001 (Photon International, 7-2001).

In Denmark, several projects on ventilated PV were carried out, as described by Pedersen [138]. In 1993, the EU-Thermie programme supported Cenergia, the Danish housing association Dansk Boligselskab and Copenhagen Energy to install $20 \mathrm{kWp}$ of PV. As part of this project, $8.6 \mathrm{kWp}$ of ventilated c-Si was integrated into the Southern facade of a high-rise building in Copenhagen. In the period 1996-2000, this was followed by the EU-Joule Project PV-Vent, aiming at low-cost ventilated PV application for retrofit housing [138-140]. Participants were Cenergia, ThermoVex Denmark, FSB, Fortum, Ecofys, PA-Energy, NTNU, the Danish Solar Energy Laboratory and the Copenhagen Energy Utility. Ventilated PV systems were developed and an architectural competition was held to make an inventory of possible designs for integration of these systems. Two multi-family buildings were fitted with ventilated PV and the systems were monitored $[139,140]$. In 1998, the Innopex Project was started, supported by EU-Thermie [138,141]. Within this project, ventilation towers were planned, made of perforated metal plate with PV modules integrated in the top. However, Rasmussen et al. [141] indicate that the PV was not installed at the ventilation towers because the tenants decided against this. Furthermore, within the scope of the Ålborg Urban Ecology Project with funding of the municipality and the Danish Ministries of Housing and Energy, the subproject 'Yellow House' was carried out by Esbensen Consulting Engineers, in which a multi storey building dating from 1900 was renovated. Within this project, PV-panels are integrated in vertical solar walls, preheating ventilation air [142].

Ventilated PV facades were also investigated in an EU Joule 2 supported project during 1994/1995 and in a subsequent UK DTI supported study on cost-effective PV cladding for commercial buildings. Participants were IT Power, Ove Arup \& Partners, BP Solar, Fraunhofer ISE, Christian Pohl GmbH and the University of Northumbria [143-147]. It was reasoned that for Northern European climates, it was difficult to use the heat of the PV facade effectively, and therefore the choice was made to use buoyancy induced by the PV for a system of assisted natural ventilation [144,146].

In 1994/1995, the ELSA building of the JRC in Ispra was retrofitted with a PV facade of $770 \mathrm{~m}^{2}([148,293]$. The research on the ELSA building started with the pilot project ECOcentre Ispra [148,149]. Within this project, also research was carried out at the University of Strathclyde in the UK, concerning modelling of a facade in ESP-r [150], and at the University of Gävle in Sweden, concerning CFD modelling of the flow in the ventilated PV façade [151-154]. Further research on PV integration was recommended, and two more EU supported projects were started on ventilated PV; the PV-façade project PV-HYBRID PAS and the PV-roof project PV-HYPRI. During the period 1996-1998 a 
large amount of research on PVT-air was carried out within the project PV-HYBRIDPAS, with the aim of developing procedures for overall performance evaluation of hybrid photovoltaic building components, that was financed through the EU Joule III program [155-164,246,245,262,296]. The project was coordinated by the BBRI (Belgian Building Research Institute), with the participation of CRES, CIEMAT, TNO, ITW, VTT, BRE, JRC, Conphoebus and the Universities of Strathclyde and Porto. The four tasks aimed at the overall performance (including aspects as maintenance, safety and aesthetics), the electrical component performance, the thermal component performance (with attention both for the module performance and the thermal interaction with the room) and the system performance. A reference component was developed and the electrical and thermal component performances were evaluated by means of parallel testing in the PASLINK test cells at the institutes involved. Different types of PV modules were tested (both a-Si and c$\mathrm{Si}$ modules). With respect to the system performance, simulation case studies were carried out for the ELSA building of the JRC in Ispra, Italy, the College Vanoise in France, the Bundtland Centre in Denmark, the Lighthouse viewing gallery in Glasgow, UK, Linford House in the UK and a teaching hospital in Greece. A large amount of the simulation work was carried out at the University of Strathclyde using ESP-r [155,156,158], while a market potential study was carried out by the BBRI [164]. The final conclusion for the ELSA building itself, however, was that the heat could not efficiently be used by the existing heating system, so it was decided not to use the heat of the PV facade (Bloem, personal communication). Simultaneously, the project PV-HYPRI was carried out during 1996-1998 with JRC Ispra, Siemens and the University of Gävle [165-168], in which the focus was on PV-roofs. Within this project, experimental research on a test façade and CFD calculations were carried out to establish the fluid flow and heat transfer for a PV-faç ade or PV-roof with natural convection at the rear.

At the University of Cardiff, a large amount of research of PV air gap modelling has been carried out in the group of Brinkworth ([169-173,264,268]. While the research by Mosfegh and Sandberg in Sweden was concentrating on natural convection in facades and roofs, Brinkworth and his co-workers also included the effects of wind pressure on the air velocity in the gap. Equations for engineering purposes were developed for both facades and roofs.

After the PV-HYPRI project, the University of Gävle continued its activities on ventilated PV within the EU supported PV-Cool-Build project with the consortium of BEAR architects, Geosolar and EETS, subcontracting Brinkworth from the Cardiff University. The project is targeting at reducing the temperature-induced losses of buildingintegrated PV ([174,175]; www.pvcoolbuild.com).

Under JOULE 3, the Building Impact project was carried out during 1999/2000, concerned with building implementation of photovoltaics with active control of temperature. Partners were the Halcrow Group, IT Power, Saint Gobain, JRC Ispra, PlusWall Ltd, Eurosolare, the University of Strathclyde and the University of Patras $[176,177,250]$. Five prototypes were tested in different modes (natural and forced convection, with and without vortex generators) at Ispra and in the UK, to identify the effect of climate. At the University of Patras, various methods were tested to increase the thermal performance, among which the use of a thin blackened metal sheet in the cavity $[76,178,295]$.

In Spain, during the period 1994/1995 the installation of a $225 \mathrm{~m}^{2}$ ventilated PV façade and a $374 \mathrm{~m}^{2}$ ventilated PV shed roof at the Mataro library was carried out within the EU Joule 2 program, with participation of TFM, the University of Barcelona, the Hochschule 
für Technik Stuttgart and GENEC [179-182,276]. A subsequent project was carried out under EU Joule 3 by CREST, Loughborough University, in coorporation with the Hochschule für Technik Stuttgart, TFM and Grammer KG during 1998/2000, with the aim of boosting the performance of the PVT façade by means of purpose designed air collectors in the upper section of the façade [183-187,190,191,244]. The design method was worked out further and presented in a number of publications [188,189,247]. Finally, during 2000-2002, the EU supported project Air-cool was carried out, in which a solar desiccant cooling system was installed at Mataro. Partners in this project were again the Hochschule für Technik Stuttgart, the University of Loughborough, TFM, Grammer, Sauter Iberica and Siegle and Epple [192,193,297].

In the USA, two demonstration projects were realised by Innovative Design and the Solar Center of the North Carolina State University, through funding from the PV:BONUS program [194]. The $25 \mathrm{~m}^{2}$ PVT system on the Central Carolina Bank in Bessemer City was realised in 1996, in which the heat was used for preheating ventilation air during the winter and vented to the ambient during the summer. The $40 \mathrm{~m}^{2} \mathrm{a}-\mathrm{Si}$ system on the Applebee's restaurant in Salisbury was realised in 1997, preheating water through a heat exchanger. Later, also work was done on a PVT liquid module [195].

In the UK, a demonstration project for ventilated PV was carried out at the Brockshill Environment Centre [196,197], containing $37 \mathrm{~m}^{2}$ of PV combined with $12.5 \mathrm{~m}^{2}$ of solar air collectors. The system is multi-operational, allowing both preheat of fresh ventilation air and recirculation of air through the PVT/collector area for water heating (used for both space heating and hot water). Also a PVT TRNSYS type was developed. Further research on ventilated PV was carried out at the Mackintosh School of Architecture within the University of Glasgow [198-202] for application of ventilated PV within the refurbishment of the Graham Hills Building, belonging to the University of Strathclyde. Simulations of the office building, including the ventilated PV, were carried out in ESP-r.

In Italy, a development trajectory for a commercial PVT-roof system (TIS) was carried out by the Politecnico di Milano and the manufacturer Secco Systemi [203]. A system was developed that can be integrated in common roofs or facades, replacing conventional building elements such as external cover, watertight layer and insulation layer. As a first commercial application of this system, the $160 \mathrm{~m}^{2}$ PVT-air roof of the eco-canteen of the Fiat research centre was realised [204-206,260,261]. In addition, the Politecnico di Milano developed a number of TRNSYS types for the calculation of PVT-air modules.

In France, within the national research CNRS Energie program, the project Hybrid PVT solar collector integrated in buildings, has been started, with participation of GENEC, the Ecole de Mines de Paris, the Ecole Normale Superieure de Cachan and the Universities of Lyon, Savoie and Cergy. Related research was carried out in which EDF, in collaboration with Ecole des Mines de Paris, under the support of ADEME, developed a TRNSYS tool for simulation of PVT, suitable for facades, roofs and solar chimneys to assist mechanical ventilation [207-209, Menezo IEA SHC task 35 presentation]. In the Netherlands, ECN did an experimental and numerical study on a BIPVT roof [50].

A large amount of research was carried out in the group of Prasad at UNSW in Australia, where $\mathrm{PhD}$ research was carried out, including experimental research and modelling of a PV-air roof during 2000-2002 with funding by ACRE and UNSW $[12,70,71,72,74,210,211,212,213,292]$.

At the Polytechnic University of Hong Kong, PV-facades were investigated together with the group of Brinkworth in the UK [173], while at the City University, research is 
carried out in cooperation with the University of Science and Technology of China and the group of Strachan at ESRU [214,252].

In Japan, Takashima et al. [216] carried out a theoretical exergy study on a PV-roof cooled by natural convection. Research on PVT-wallboard elements for facades was carried out at Hokkaido University [217,218], resulting in thermal efficiencies of 20-22\% for unglazed modules and $29-37 \%$ for glazed modules.

\section{Module aspects PVT liquid- and air-collectors}

\subsection{Manufacturing aspects}

The most basic technique to manufacture a PVT collector is to glue either PV cells or an entire commercial PV laminate to the absorber of a commercial thermal collector. This technique was applied in many research projects (e.g. [32,43,86]). The drawback of glueing PV cells is the fact that the PV will not be sufficiently protected from the ambient (in particular from moisture), which makes this technique problematic for commercial application. In addition, problems may result due to insufficient electrical insulation. These problems do not occur if a commercial PV laminate is connected to a thermal absorber, e.g. by glueing. However, this method also has some drawbacks: the thermal resistance between the PV laminate and the absorber may become too large for good thermal performance (especially when air enclosure in the glue layer is significant) and the additional glueing step is not optimal for commercial manufacturing. Furthermore, the white tedlar rear that is generally used for c-Si modules, has relatively large reflection losses.

A more advanced technique is to laminate the whole package of top cover, PV cells, electrical insulation and absorber together in one step. If a metal absorber is used, good care should be taken that the electrical resistance between the PV cells and the metal absorber remains sufficiently large. Therefore, normally an additional electrically insulating foil is laminated between the cells and the absorber, but also an electrically insulating coating may be applied directly to the absorber. High-temperature lamination may result in a slight bend of the PVT laminate, due to the difference in thermal expansion between the glass top cover and the metal. The use of a top foil (e.g. clear tedlar) instead of glass would reduce this problem, but the absence of the glass requires the absorber to be sufficiently rigid to provide the necessary support for the cells. PVT strips with plastic top foil have been used in the PVT work of Racell, where the support was provided by the copper tube along the centre of the strip. Komp [219] shows PVT strips made of galvanised sheet metal, in which the support is provided by bending the corners of each strip, resulting in a $\Pi$-shaped profile, and soldering the copper tubing into the two corners. A number of sheet-and-tube absorber configuration designs are compared by Affolter et al. [280].

Furthermore, for a sheet-and-tube absorber, the tubes provide a non-level rear that complicates the handling in the case of subsequent lamination of the PV to the absorber, leading to increased handling time during production (soldering the tubes after lamination is normally not feasible because the soldering temperature would damage the encapsulant, whereas glueing the tubes may compromise reliability and heat transfer). Instead of a sheet-and-tube absorber, also an extruded aluminium plate may be applied, as used by Chow et al. [233]. 
Whichever technique is chosen, one should take care that the encapsulant (and any foils that may be used) are able to withstand the high temperatures that occur in stagnating glazed PVT modules, which can be as high as $130^{\circ} \mathrm{C}$ [51]. In addition, the optical properties of the PV cells should be sufficiently good; not all commercially available PV cells are equally suitable for PVT application due to differences in reflection losses in the infrared.

Instead of lamination, a low-temperature encapsulation technique may be used, such as the application of silicones, which have a very high resistance to high temperature (see e.g. Komp [219]). For the electrical insulation, Komp first applies a layer of silicone over the absorber onto which he presses a layer of cloth, followed by a second layer of silicone for the fastening of the cells. However, for commercial production silicones have some drawbacks as they are difficult in term of handling and have the risk of air entrapment.

For unglazed modules, low-cost plastic pool collectors or channel-plate absorbers may be applied. In this case, only low-temperature and low-pressure connection methods such as glueing or low-temperature lamination can be used, since otherwise the absorber will be damaged. Research has been carried out in finding high-temperature-resistant plastics suitable for glazed application as well [84], which has been used to develop a prototype PVT collector by Sandnes and Rekstad [86]. Sandnes warns that the difference in thermal expansion between the cells and the plastic absorber is substantial, which he overcame by applying a layer of elastic silicone adhesive. Affolter et al. [280] compares different options for plastic absorber configurations. In addition, work has been carried out on laminating flexible a-Si modules to a pool collector [105], but re-laminating an already laminated PV module seems problematic, as delamination of the PV may result if the applied relamination temperature is too high.

\subsection{Thermal module efficiency}

\subsubsection{Introduction}

Thermally, a PVT module is similar to a solar thermal collector. As in the case of a solar thermal collector, a good efficiency requires a good solar absorption and a good heat transfer. Furthermore, the higher the required temperature level, the higher the required amount of insulation, where 'insulation' refers both to the effect of side and rear insulation, e.g. by mineral wool, as well as the top insulation due to an additional transparent cover and other means to reduce top losses such as a low-emissivity coating. Typical thermal and electrical efficiency curves for a PVT collector are indicated in Fig. 1. Although the electrical efficiency is a function of temperature and not of reduced temperature, the figure for the electrical efficiency also shows the corresponding reduced temperature on the $x$-axis, to allow comparison with the figure for the thermal efficiency. The figure clearly shows that the glazed module has a higher thermal performance than the unglazed module, especially at higher reduced temperatures. Also for PVT air collectors, the literature indicates the strong increase in thermal performance if a top glazing is used e.g. [130,217]. At the other hand, the glazing slightly reduces the electrical performance due to additional reflection at the cover. For reference, the figures also show the thermal efficiency of a conventional solar thermal collector and the electrical efficiency of a PV laminate. In this paragraph, only the thermal efficiency will be discussed, whereas the next paragraph will elaborate on the electrical efficiency. From the figure for the thermal efficiency, it is obvious that the thermal efficiency of a PVT collector is substantially lower 
a

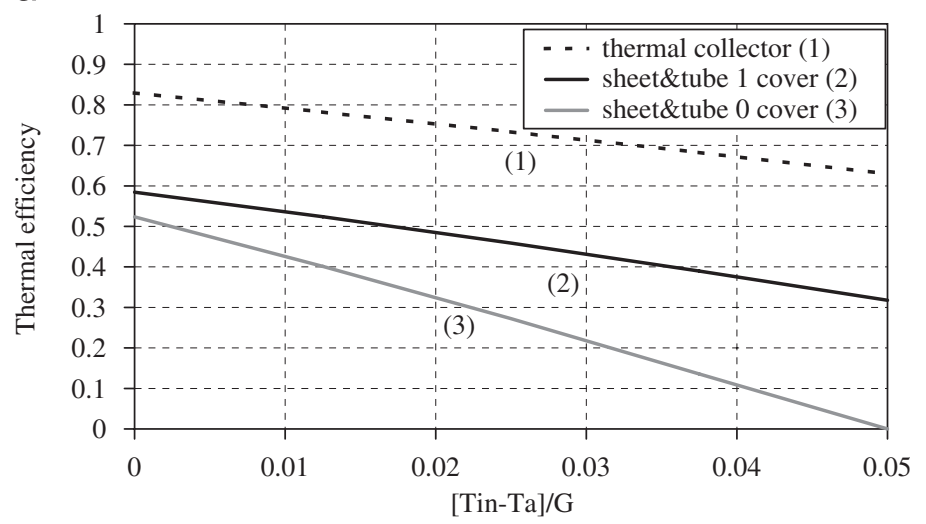

b

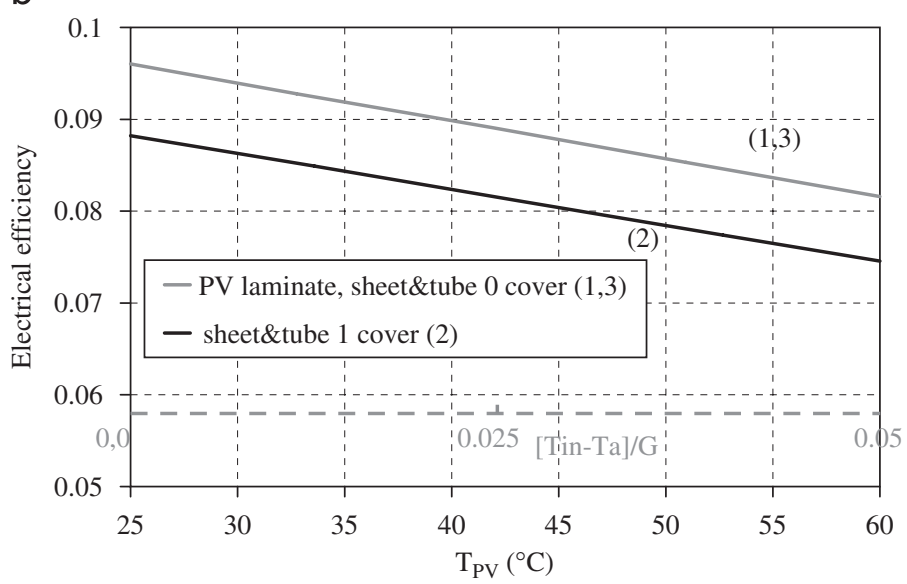

Fig. 1. Efficiencies of a PVT-liquid collector, a thermal collector and a PV laminate. (a) Thermal efficiency (no electricity production by PVT), (b) corresponding electrical efficiency (although the electrical efficiency is a function of PV temperature and not of reduced temperature, for comparison purposes, a secondary $x$-axis is indicated, displaying the reduced temperature assuming $G=800 \mathrm{~W} / \mathrm{m} 2$, corresponding to the calculation shown in the upper figure).

than that of a conventional collector, especially at higher values of the reduced temperature. The reduction in thermal efficiency is due to 4 effects:

1. the absorption factor of the PV-surface is lower than the absorption factor of a conventional collector surface due to reflections at the various layers in the PVlaminate;

2. the PV-surface is not spectrally selective, resulting in large thermal radiation losses;

3. the heat resistance between the absorbing surface and the heat transfer medium is increased due to additional layers of material. This implies a relatively hot surface of the PVT-panel, leading to additional heat losses and a small decrease in electrical performance and

4. the energy that is converted to electrical output is lost for the thermal output. However, as this effect is intended, it will not be discussed further. 


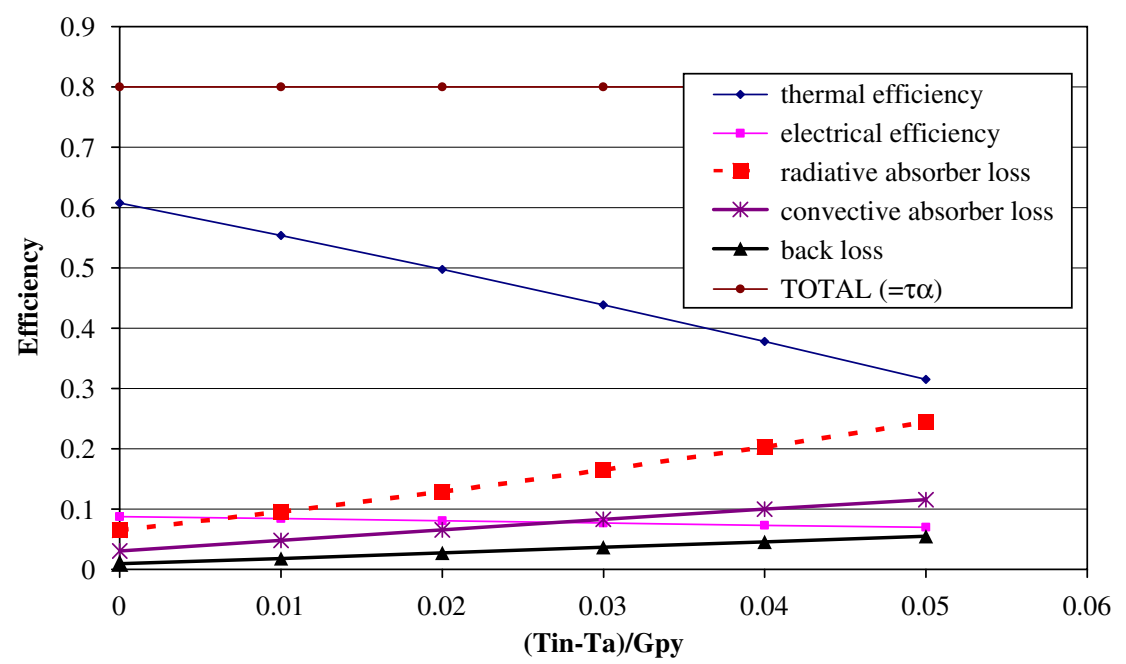

Fig. 2. The loss mechanisms in the PVT panel as a function of reduced temperature-thermal balance over the PVT absorber for a glazed PVT module. Note the large effect of radiation losses from the PVT absorber to the top glass, compared to convective and back loss.

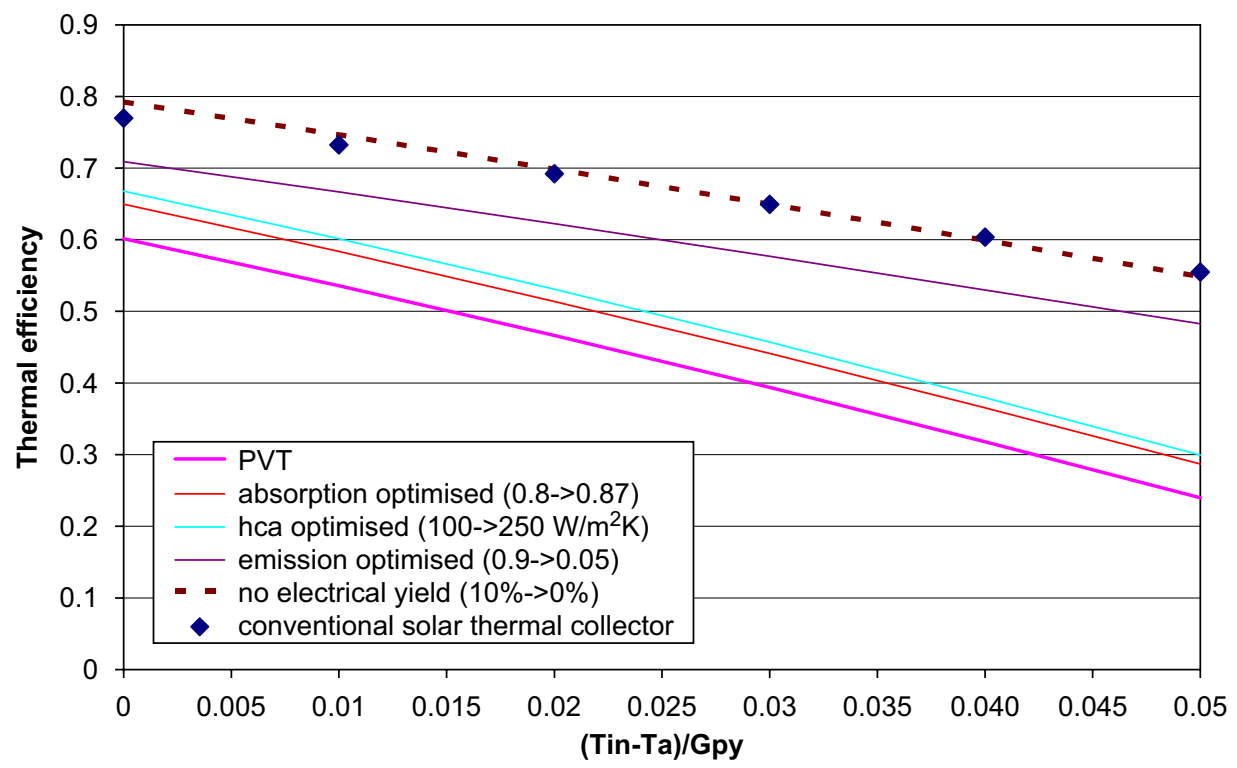

Fig. 3. Starting from the efficiency curve for the PVT module, successively removing the special features of the PVT module finally results in the curve for a conventional solar thermal collector. $H_{\mathrm{ca}}$ is the heat transfer coefficient between cells and absorber.

These effects are further illustrated by Fig. 2. This figure shows the relative magnitude of the different loss terms, for the case of a typical glazed PVT module consisting of a conventional PV c-Si module glued to a solar thermal collector. In addition, Fig. 3 indicates the effect of the successive removal of these loss terms. It is clear that the effect of 


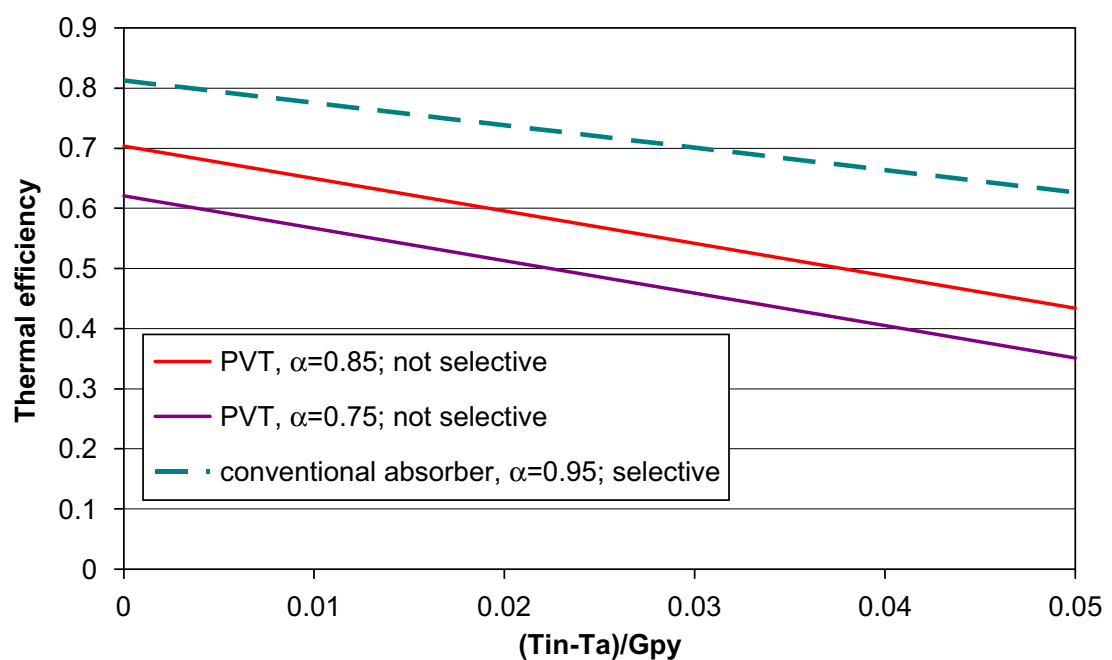

Fig. 4. Thermal efficiency versus optical characteristics absorber (no electricity production).

low absorption and the radiative loss are responsible for the largest reduction in PVT performance, while also the effect of the thermal resistance is substantial.

The three loss mechanisms (reflection loss, spectral selectivity and thermal resistance), will be the subject of the following paragraphs. Figs. 1 and 2, as well as a number of other figures later in the article (Figs. 3, 4, 6, 7, 10,11) were calculated with the model described by Zondag et al. [45].

\subsubsection{Reflection losses}

3.2.2.1. Introduction. The relatively low transmission-absorption factor is an important loss mechanism in PVT collectors. Typically, the absorbers of solar thermal collectors have an absorption of up to $95 \%$, while PVT absorbers are typically limited to $75-85 \%$, depending on the PV type and the absorbing surface underneath (which may be a black absorber but also a white PV rear foil). The effect of the transmission-absorption on the efficiency curve is indicated in Fig. 4. Five aspects have been found in the literature on the absorbance of PVT-collectors:

1. reducing reflection at the additional top cover (in case of a glazed module);

2. reducing reflection at the PVT-absorber top surface;

3. reducing reflection at the PV top grid;

4. increasing absorption in PV and rear contact and

5. increasing absorption in the opaque surface below the PV.

These aspects will be described in more detail in the next 5 sections.

3.2.2.2. Reflection at the additional top cover. For glazed PVT collectors, the reflection at the top cover affects both the electrical and the thermal performance. Typically for glazed conventional and PVT collectors, low-iron glass is used for the top cover, with a transmission of about $91-92 \%$. In recent years, glass with $96 \%$ transparency is becoming 
available from the companies Flabeg and Sunarc. This glass is suitable for both collector glazing [221] and PV coverage [222], and seems very interesting for PVT application. Plastic cover materials offer potential for cost savings (both materials and handling), but lower optical performance and lower reliability (associated with thermal expansion and UV degradation, see e.g. [223]) make such materials less suitable for PVT applications. In the literature on PVT systems, no PVT collectors with plastic covers were found. In the research of Sandnes and Rekstad [85], the polycarbonate cover of their Solarnor collector was replaced with a glass cover when the collector was converted to a PVT. However, the search for appropriate plastic cover material is continuing $[224,225]$.

3.2.2.3. Reflection at the PVT absorber top surface. For PVT-absorbers, mostly low-iron glass is used, which results in a reflection loss of about $4 \%$ (the reflection at the rear of the glass is almost zero due to the good matching with the index of refraction of the encapsulant). Also here, the highly transparent glass mentioned above may be an interesting option to reduce the reflection loss further. Apart from glass, also plastic covers are used (flexible thin-film modules).

- Absorption measurements were carried out within the SDA project [106] for a USSC a-Si module. For bare a-Si, an absorptivity was found of $70 \%$. For the module with different cover materials (Urethane, Tefzel, fibreglass), values of $67-75 \%$ were found.

However, if plastic covers are used in glazed PVT application, care should be taken that the plastic can withstand the stagnation temperature. As an example, Hendrie [18] reports on the first generation ARCO PVT-air collector with a Teflon film over the PV-cells. It was found that the Teflon film was not stable at the operating temperatures encountered during testing. The film outgassed, degrading the optical transmission of the cover by $10-15 \%$.

In addition, when considering plastic covers, one should be aware that crystalline cells require a rigid support that is normally provided by the glass, and that now should be provided by other means, as explained previously.

3.2.2.4. Reflection at the top grid. In a conventional crystalline PV laminate, reflection occurs at the silver tabs and fingers. Although the reflection is large, the area taken by the top grid is small, which makes this effect of secondary importance. In the past, research has been carried out on PVT cells with the aim of increasing the absorption of the top grid to improve the thermal performance, but this has not lead to satisfactory results.

- Experiments were done by Younger et al. [26], who tried to blacken the top grid by various methods. First he tried tellurium-oxide, which was unsuccessful due to poor adhesion to the silver contacts, the instability of the oxide - turning the coating into white tellurium-dioxide - and its non-selective character, which reduced cell output. Next, a black chrome plating method was tried, which created soldering problems. Then sodium cyanide-based black electroplate was applied, which turned out to remove the $\mathrm{TiO}_{2}$ anti-reflective coating. The author suggested that the latter technique might well be compatible with other anti-reflective coatings such as $\mathrm{Ta}_{2} \mathrm{O}_{5}$ or $\mathrm{Al}_{2} \mathrm{O}_{3}$, but these options were not tested anymore. 
- Loferski et al. [112] blackened the top-grid of a textured cell with anti-reflection coating and then measured the absorptance. This was found to increase by top-grid blackening from $93 \%$ to $94 \%$, which was too low to be cost effective.

However, since then techniques have been developed to reduce the metal coverage by the top grid further. Santbergen and Van Zolingen [226] indicate that while the traditional H-pattern results in a total cell absorption of $85 \%$, the PUM cell concept (ECN) reduces this to $87 \%$ and the EWT cell concept (Sandia) to $90 \%$. Given this reduction of the top grid area by these modern techniques, the early research on blackening of the top grid has lost its significance.

For thin film PV, grid reflection does not occur since transparent top contacts are used for which transparent conducting oxides (TCO) are applied. TCO layers may have a significant absorption, which in the case of PVT contributes to the thermal efficiency of the module.

3.2.2.5. Reflection at the $P V$ cell and rear contact. Due to the fact that a large difference exists between the indices of refraction of the silicon and the EVA in the PV laminate, the silicon is coated with an anti-reflection coating in order to reduce the reflection at the top of the cell. The effect of an anti-reflection coating depends strongly on the wavelength of the incoming light: the minimum in reflection occurs for light of a wavelength that is equal to 4 times the optical thickness of the coating. The thickness of the coating is optimised to obtain optimal transmission of solar light with energy larger than the bandgap of the cell material. This may not be optimal for PVT applications, since PVT also uses the long-wave part of the solar spectrum for the production of heat. Another technique to reduce the reflection at the silicon surface is by surface texturing. The effect of texturing is particularly suitable for PVT-systems, since texturing also reduces the long-wavelength reflection (e.g. [227]).

Due to a lower reflection, more light is coupled into the silicon. However, now the absorptive properties of the cell become important. Crystalline silicon is a good absorber in the spectral range between $0.5-1.1 \mu \mathrm{m}$. but is almost transparent for light with wavelength longer than $1.1 \mu \mathrm{m}$. In a PV-system, this long-wavelength energy is not useful as it cannot contribute to the generation of electrical energy, but for a PVT-system this energy should be retained for heat production. In case of crystalline silicon cells, only about $70 \%$ of the solar spectrum (the part of the irradiance with energy larger than the bandgap minus some reflection losses) is absorbed by the silicon due to its intrinsic properties. For the part with energy lower than the bandgap, Santbergen and Van Zolingen [226] indicate the important role of free carrier absorption. Free carrier absorption is induced by the doping of the silicon (particularly in the highly doped emitter). This absorption will contribute to the heat produced in the cell. Santbergen and Van Zolingen [226] indicate that in a typical cell configuration more than half of the below-bandgap radiation can be absorbed by this mechanism, resulting in a typical absorption for an untextured cell of about $86 \%$ for the active area, as shown in Fig. 5.

- Absorption measurements have been carried out by Affolter et al. [228,281] and Platz et al. [229]. For various types of a-Si cells, Affolter found that the absorption over the solar spectrum varied between $71 \%$ and $91 \%$. Platz found this absorption to be within 


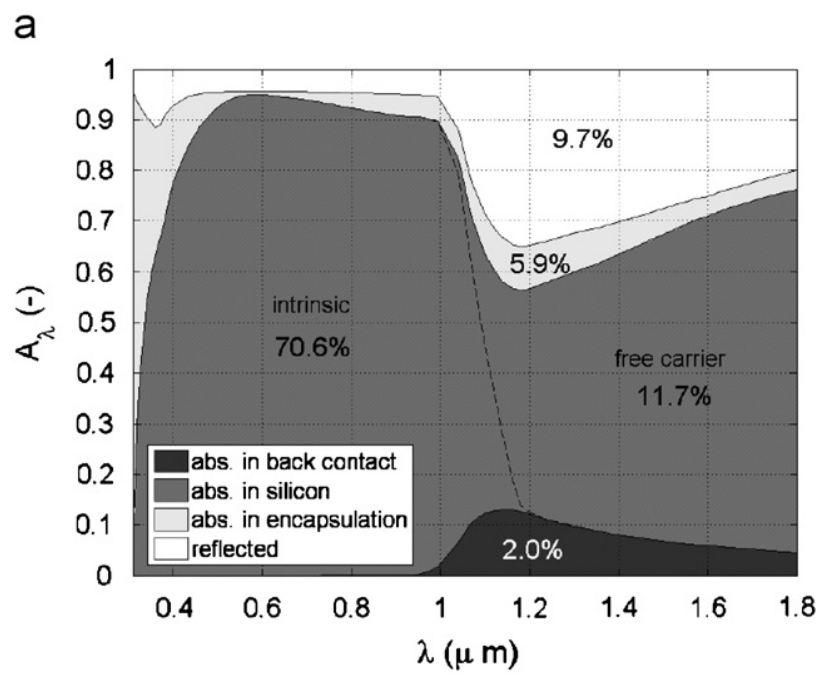

b

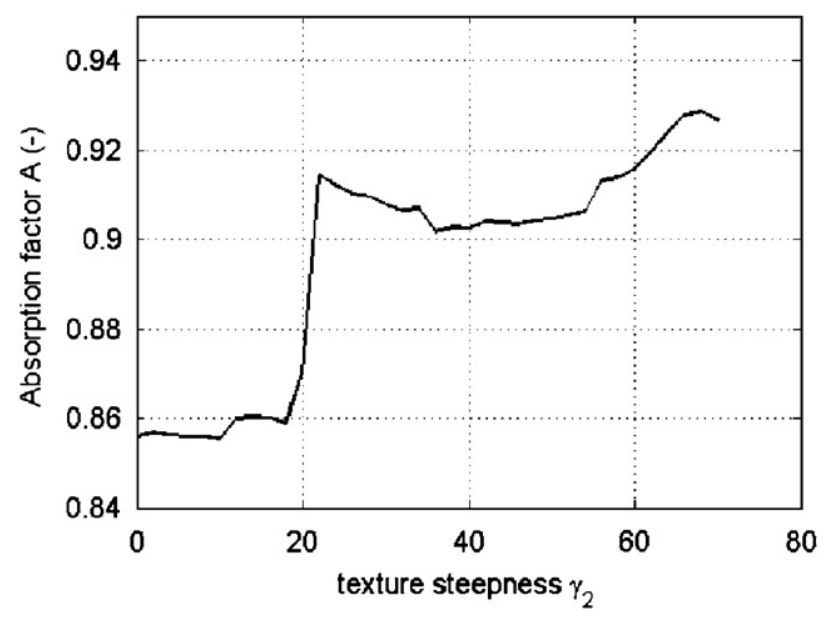

Fig. 5. (a) Absorption in the various layers of the PVT absorber for c-Si cells as calculated by Santbergen and Van Zolingen [226], (b) absorption as a function of texture steepness cells [226].

the range $78-85 \%$ for various encapsulated a-Si cells, while $88 \%$ was found for an encapsulated multi-crystalline Si cell.

To prevent the loss of the energy that is reflected at the back contact, use can be made of the fact that the light can escape from the silicon only if the angle is smaller than the critical angle for internal reflection. If the angle is larger than the critical angle, internal reflection of the light occurs, effectively trapping the light within the cell. It this case, the light will go through multiple reflections, strongly increasing the length of the mean path of the photon through the silicon and thereby increasing the chance that the photon will be absorbed. Therefore, the absorption can be increased further by a suitable choice of texture, type of metal used for the rear contact and rear surface roughness [226,227]. Santbergen and Van 
Zolingen [226] present the absorption as a function of texture steepness, as shown in Fig. 5. In addition, they indicate that the absorption can be increased by $3 \%$ by using a chromium back contact.

3.2.2.6. Absorption in the absorber surface below the $P V$. A different strategy is not to absorb all energy in the cell, but to let part of the long-wave irradiance proceed to a secondary absorber underneath. This requires the use of a back contact grid instead of a solid-back contact. However, reflection at the back contact grid (covering usually 20-30\% of the area), as well as reflection at the silicon-EVA interface (normally without AR coating), can be substantial.

- Santbergen and Van Zolingen [227] simulated different crystalline silicon configurations for PVT application, investigating the effect of roughness, the back contact material and an anti-reflection coating on the back of the cell that was optimised for transmission of the part of the solar radiation below the bandgap energy. It was concluded that the strategy to increase the transmission of the cell for longwave radiation and to absorb this radiation in a secondary absorber underneath, as well as the strategy to increase the absorption of this energy into the PV cell by means of increased roughness, are both suitable strategies for creating a significant increase in the absorption of the solar radiation, as compared to standard crystalline silicon cells.

- The simulations by Cox and Raghuraman [23] showed an increase from $34 \%$ to $39 \%$ in thermal efficiency due to back contact gridding in combination with a separate absorber underneath. Younger et al. [26] found that, although the gridding introduced a small performance penalty due to higher resistance losses in the contact grid, silicon cell performance was still as high as $15 \%$. Hendrie [18] also reported negligible cell performance losses due to the additional resistance. In addition, it should be noted here that back contact gridding is a technique that has also been used in many commercial modules.

- Lalovic et al. [38] find that $29 \%$ of the incoming light is reflected at the aluminium back electrode of his a-Si PVT-system. He suggests to use an ITO back electrode, which is transparent for the solar spectrum, and to have a black absorbing collector surface underneath. His experiments indicate a thermal efficiency of $52 \%$ for an aluminium back electrode compared to $65 \%$ for the ITO back electrode.

- A back contact grid was also reported by Hayakashi et al. [88], who put underneath his PV-cells a thermal collector consisting of glass tubes filled with a strongly absorbing black collector fluid. In this way, long-wavelength radiation is directly absorbed by the collector fluid. The PV-cells were connected to the thermal absorber by means of an aluminium strip which was located midway between the silicon cells in order to collect heat from the PV as well. He reported a thermal efficiency at zero reduced temperature of approximately $64 \%$ and simultaneously an electrical efficiency of $8 \%$.

However, it should be realised that the transparency of the cells is limited due to the large free-carrier absorption (as indicated by Santbergen and Van Zolingen [226]). This effect implies that only a small part of the irradiance will make it through the cells to the secondary absorber. However, the secondary absorber will still function to catch light that was transmitted through the spacing between the cells. The secondary absorber may be the rear surface of the PVT absorber. If a commercial PV laminate is used, this is the PV rear foil, which may be of various colours, affecting the magnitude and the spectral variation of 
the absorption factor. If the cells are laminated to a solar thermal absorber, the solar absorption will be high and largely independent of the wavelength. However, in the case in which the collector medium flows through a channel, it is also possible to have a transparent PV laminate and to have the secondary absorbing surface at the other side of the channel (below the collector medium). In this way, the collector medium is enclosed between the primary absorber (with the PV cells) and the secondary absorber, which makes the heat transfer from the collector to the medium more efficient. In the PVT literature, this option is mainly found in PVT-air systems:

- In the air-type collector investigated by Raghuraman [109], air flows between the upper absorber consisting of PV-cells and the lower absorber consisting of a black thermal absorber. He finds a thermal efficiency of $42 \%$.

- Cox and Raghuraman [23] performed simulations on the collector design of Raghuraman as described above. They concluded that for sufficiently large cell coverage the secondary absorber underneath the silicon cells should not be spectrally selective since the reduced energy loss due to low emission is offset by the reflection of long-wavelength radiation that is emitted by the hot upper absorber.

- Zondag et al. [46] calculated the thermal efficiency of a PVT-liquid channel collector, with either the channel underneath opaque PV, or the channel underneath transparent PV with a secondary absorber at the rear. It was found that for the case with the additional rear absorber, the thermal efficiency was $63 \%$ instead of $60 \%$ for the opaque PV case. For air collectors, in which the heat transfer to the collector fluid is more critical, this effect will be larger.

In summary, various methods have been examined to reduce the reflection of long-wavelength radiation by the PV: texturing of the silicon to reduce reflection [18,26,25,112,226,227], light

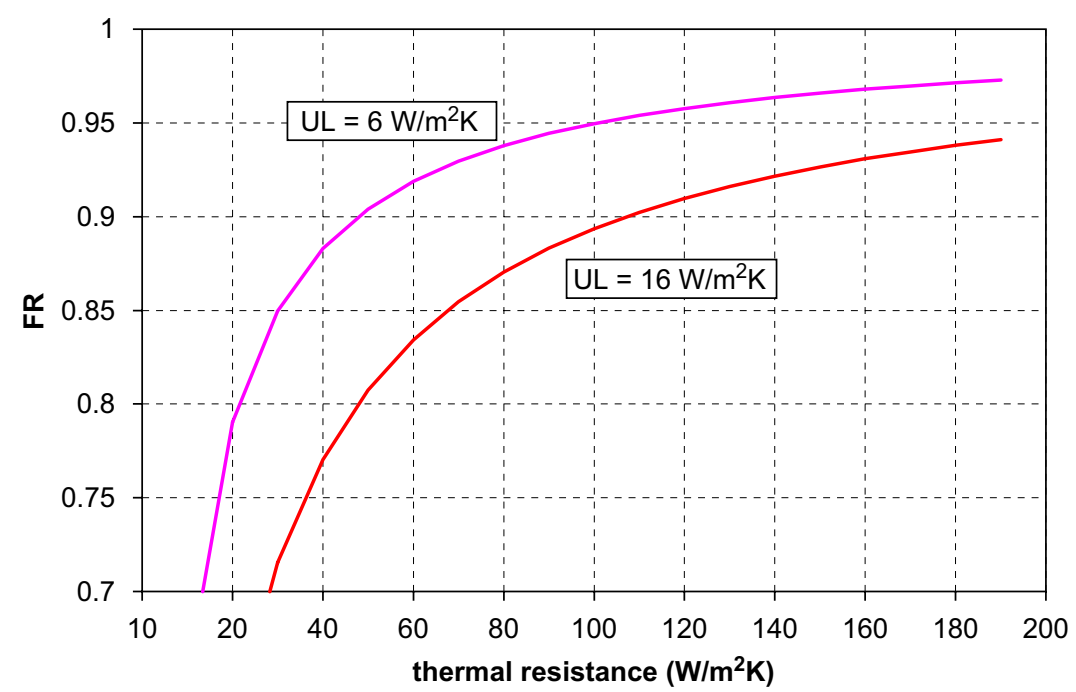

Fig. 6. Thermal efficiency versus heat transfer coefficient (PVT-liquid collector; calculated from Hottel-Whillier model adapted for PVT as described in Zondag et al. [45]. $U L=6 \mathrm{~W} / \mathrm{m}^{2} \mathrm{~K}$ corresponds to a glazed PVT module and $U L=16 \mathrm{~W} / \mathrm{m}^{2} \mathrm{~K}$ to an unglazed module. 
trapping by optimised texture and back contact roughness [18,226,227], a highly absorbing back contact [226,227] and a transparent back electrode (back grid for c-Si or TCO for a-Si), to increase rear transmission, with an absorbing surface underneath $[23,26,38$, $88,227]$. However, for the last case, it should be realised that the transparency of the cells themselves is limited due to the large free-carrier absorption (as indicated by Santbergen and Van Zolingen [226]).

\subsubsection{Thermal resistance}

3.2.3.1. Heat transfer from PV to absorber. The thermal resistance between the PV-cells and the collector fluid should be minimised. A low heat transfer results in a large temperature gradient and therefore in a high PV temperature. This decreases both thermal and electrical efficiency. The first consideration should be to keep all layers of material between the silicon and the absorber as thin as possible and preferably have them made of materials with a high thermal conduction. In practice, however, this can be quite complicated, especially since also a good electrical insulation should be guaranteed, which may require additional layers of electrically insulating material. The effect of thermal resistance on the heat removal factor FR is shown in Fig. 6. The heat removal factor is directly related to the efficiency by $\eta=\mathrm{FR} \times\left[\tau \alpha-U \times\left(T_{\text {in }}-T_{\mathrm{a}}\right) / \mathrm{Gpy}\right]$, where $\tau$ is the transmission-absorption coefficient, $\mathrm{U}$ is the collector loss coefficient and $\mathrm{Gpy}$ is the irradiation. $T_{\text {in }}$ represents the collector inflow temperature and $T_{\mathrm{a}}$ the ambient temperature. It can be seen that a good heat transfer is particularly important for unglazed PVT.

- Van der Ree [41] studied a PV-laminate that was clamped to a plastic thermal absorber. A corrugated copper foil was set between the PV and the absorber to improve the thermal contact. It was found that-due to the pressure being exerted only at the sides - the construction was slightly convex, leading to an increase in thermal resistance in the middle of the prototype. This resulted in a temperature difference of $13{ }^{\circ} \mathrm{C}$ between the mean liquid temperature and the PV and a substantial decrease of the thermal efficiency. The contact could not be improved by an increase in the pressure exerted by the rear insulation. The problem could not be solved for the given clamping construction.

- Hendrie [18] found that for an average fluid temperature of $28{ }^{\circ} \mathrm{C}$ the cell temperatures were $63{ }^{\circ} \mathrm{C}$ for the first generation ARCO PVT-liquid under study. This was attributed to a mechanical seal that left large air gaps between absorber and the tubes.

- Poor thermal contact was also reported to be a problem by Sudhakar and Sharon [230] who found a temperature difference of about $15^{\circ} \mathrm{C}$ between PV-laminate and water output temperature for their unglazed PVT. The poor thermal contact was ascribed to the additional thermal resistance of the PV laminate and the fact that the tubes were clamped to the absorber.

- In order to increase the heat transfer, De Vries [43] applied an aluminium-oxide-filled two-component epoxy glue to connect a conventional PV-laminate to a sheet-and-tube absorber. Due to the aluminium oxide, the glue was reported to have a heat conductance of $0.85 \mathrm{~W} / \mathrm{m} \mathrm{K}$ but in practice a lower value was found. This led to a heat transfer coefficient of $45 \mathrm{~W} / \mathrm{m}^{2} \mathrm{~K}$ between the cells and the absorber. The numerical model indicated that this thermal resistance reduced the yearly averaged efficiency of his glazed PVT-liquid collector by $4 \%$ (from $37 \%$ to $33 \%$ ). 
- Raghuraman [109] reports on a PVT-liquid system consisting of solar cells that are glued directly (no tedlar or EVA in between) to the thermal absorber plate. Between the plate and the cells is a layer of electrical insulation to avoid short-circuiting the PVlaminate, consisting of a rather thick layer of silicone pottant. The thermal conductivity of the silicone is $0.2 \mathrm{~W} / \mathrm{m} \mathrm{K}$ and the thickness of the layer is $0.5 \mathrm{~cm}$, which results in a heat transfer of $40 \mathrm{~W} / \mathrm{m}^{2} \mathrm{~K}$. Due to the high thermal resistance of this layer, he finds a temperature difference of $12{ }^{\circ} \mathrm{C}$ between the absorber and the PV-cells, which reduces the thermal efficiency by more than $10 \%$.

- Younger et al. [26] reports on a PVT-liquid system consisting of silicon cells laminated with EVA on a copper absorber that is covered with a Mylar sheet of $50 \mu \mathrm{m}$ thickness to provide electrical insulation. The Mylar is connected to the copper absorber by a black thermally conductive epoxy EC No 285 [25].

- Suzuki et al. [32] reports on experiments using a silver-filled glue that he used to glue solar cells directly to the thermal absorber plate. In order to isolate the PV-cells electrically, he created a galvanic separation between neighbouring solar cells by using an absorber-plate that consisted of metal parts separated by non-conductive material. In this way he created an absorber surface consisting of 18 electrically separated strips, which were connected in series, each strip containing 6 mono-crystalline silicon cells (which were therefore connected in parallel). In addition, he created an 'insulate mount' PVT-system, where each individual cell was separated from the absorber surface with an $\mathrm{Al}_{2} \mathrm{O}_{3}$-plate.

- Lalovic et al. [38] uses a silicone-based adhesive (Dow Corning 282) to glue a-Si cells to a thermal absorber. He claims that this adhesive has a good thermal conductance and stays stable and elastic at all temperatures.

- Gibbons and Murphy [231] have investigated the effect of lamination parameters (lamination temperature, melting time $t_{\mathrm{EVA}}$ and post-curing time $t_{\mathrm{pc}}$ ) on the thermal interface resistances in a laminate. It was found that the observed variation in interfacial resistance in their modules could be explained for $56 \%$ by the formula

$$
\mathrm{TIR}=0.84-0.101 t_{\mathrm{pc}}+0.0021 t_{\mathrm{EVA}}+0.0245 T,
$$

where the thermal interface resistance TIR is in $\mathrm{K} / \mathrm{W}, t_{\mathrm{EVA}}$ and $t_{\mathrm{pc}}$ are in minutes and the lamination temperature $T$ is in ${ }^{\circ} \mathrm{C}$. In the examined laminates, approximately $30 \%$ of the total laminate thermal resistance was due to the effect of the thermal interface resistance.

From the perspective of heat transfer, the ideal method would be to deposit the PV material directly on the absorber. However, this can only be done for thin film techniques and requires an insulating coating or galvanic separation between the cells (as applied in flexible a-Si modules).

- Lalovic et al. [39] reports on direct depositioning of a-Si for a PVT module. He was experimenting with depositing a-Si on an aluminium absorber that was covered by an electrically insulating oxide film. However, no results on the thermal yield have been reported.

Since the late 1980s, substantial developments have taken place in this area. Electrical insulation can be obtained by suitable oxide layers, as well as glass-type layers such as 
enamel [232]. These could also be used in PVT designs. Furthermore, USSC commercially produces a-Si on steel foil (with a galvanic separation between strips of active a-Si material). Affolter et al. [280] did a feasibility study, in which he also examined the possibility to use flexible a-Si laminates with a steel foil substrate for application in PVT collectors. Flexible PV laminates were also used in a number of other PVT projects, such as the PV:BONUS projects involving Powerlight [105] and SDA [106].

3.2.3.2. Heat transfer from absorber to liquid. Conventionally, a sheet-and-tube design is used for solar collectors. The thermal efficiency of a sheet-and-tube collector depends on its ratio of $W / D$, in which $W$ is the distance between the tubes and $D$ is the tube diameter. The $W / D$ ratio used in practise is a compromise between optimised heat transfer and economic aspects (more copper tube increases material cost and handling). However, the optimum for a PVT system is not necessarily the same as for a conventional solar thermal collector. In addition, one should realise that a reduction of the $W / D$ ratio has two effects; one is the increase of the fin efficiency due to the shorter fin length, while the other is a decrease of the flow velocity in the case of parallel risers (due to the increased flow area, assuming the flowrate is kept constant) or an increase in pressure drop in the case of a spiral tube. The effect of tube spacing on FR is indicated in Fig. 7 for the case of a constant tube diameter and fixed specific flow rate, for either a spiral tube or parallel risers. The figure clearly shows the effect of the transition from turbulent to laminar. In addition, the figure shows that the potential gains of reducing the tube spacing are limited.

For liquid collectors, efforts have been undertaken to improve the heat transfer from the absorber to the liquid. The best heat transfer is obtained by leading the heat-collecting medium through a thin channel over the full width of the absorber. The water pressure requires a rather small span width (as can be seen from the Timoshenko formula), which would lead to a channel-plate design, e.g. from extruded aluminium. Although a thin channel is very interesting from the point of good heat transfer and small temperature gradients, the difficulty of the use of such channels is often in the design of the header, to obtain a sufficiently reliable construction with low-pressure loss and an even flow distribution. In addition, one should realise that the potential gains are limited, given the fact that the heat removal factor in a conventional sheet-and-tube collector is large, and that the channel should be sufficiently thin to increase the heat transfer, because $h=N u \times k / D$ with $D$ the hydraulic channel diameter.

- Huang et al. [93,94] built 2 unglazed PVT prototypes based on a sheet and tube construction. They used $W / D$ ratios of 10 (copper tube to aluminium plate) and 6.2 (extruded tube-in-sheet aluminium). Since they found that the thermal performance was not satisfactory, it was decided to build a polycarbonate multi-channel structure $(W / D=1)$. The temperature difference between the PV and the water in the tank was found to be $4{ }^{\circ} \mathrm{C}$. For an $M / A$ ratio of $821 / \mathrm{m}^{2}$, an electrical efficiency of $9 \%$ was found, together with a characteristic daily efficiency of $38 \%$. Tiwari and Sodha [129] did a simulation study based on the collector system of Huang et al. [93,94] (for $M / A=87 \mathrm{~kg} /$ $\mathrm{m}^{2}$ ), for which a thermal efficiency of $35 \%$ was calculated together with an electrical efficiency of $9 \%$.

- Chow et al. [233] built a thermosyphon PVT system with an PVT module based on an extruded aluminium channel absorber with a $W / D$ ratio of 1 to obtain an optimal heat transfer to the fluid. For an $M / A$-ratio of $65.2 \mathrm{~kg} / \mathrm{m}^{2}$, He et al. [97] measured an average 

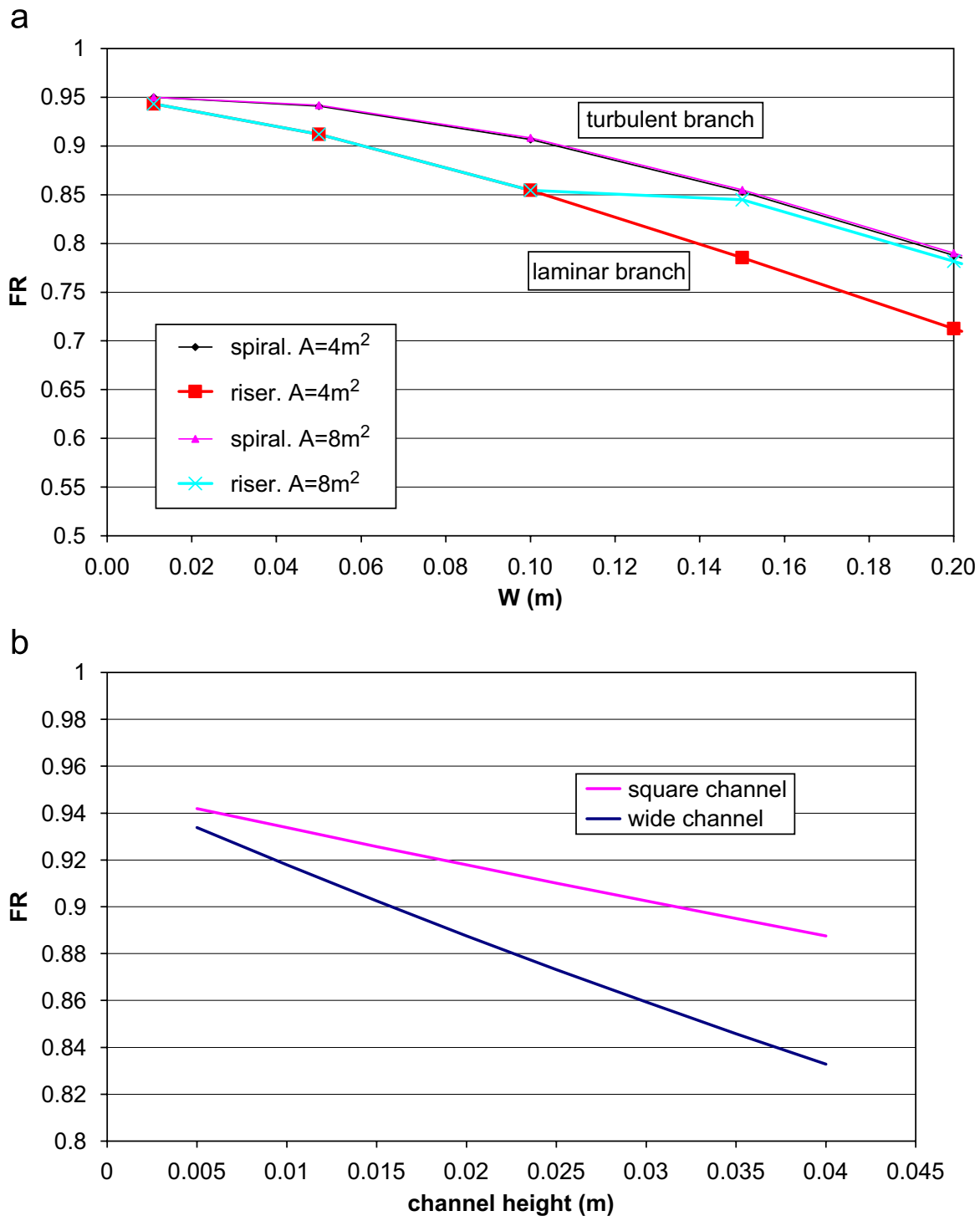

Fig. 7. (a) Sheet-and-tube collector: Thermal efficiency versus tube configuration (assuming $8 \mathrm{~mm}$ tubing and a flow of 50 liters $/ \mathrm{m}^{2}$ ). (b) channel-plate collector: Thermal efficiency versus channel width. In both cases, the thermal resistance between cells and absorber is assumed very small. The figures are calculated from the Hottel-Whillier model adapted for PVT as described in Zondag et al. [46]. Calculations that also include entrance effects are presented by Ji et al. [96].

daily thermal efficiency of $0.394-0.169\left(T_{\text {initial }}-T_{\text {ambient }}\right) / H_{\text {day }}$ for this module, for the case with a glass cover. The module electrical efficiency is about 5\% (c-Si is used, but only $50 \%$ of the absorber is covered by PV). For an improved prototype in which the collector area was fully covered with PV cells, Ji et al. [234] present over $45 \%$ average daily efficiency while the electrical efficiency was about $10 \%$. In addition, Ji et al. [96] 

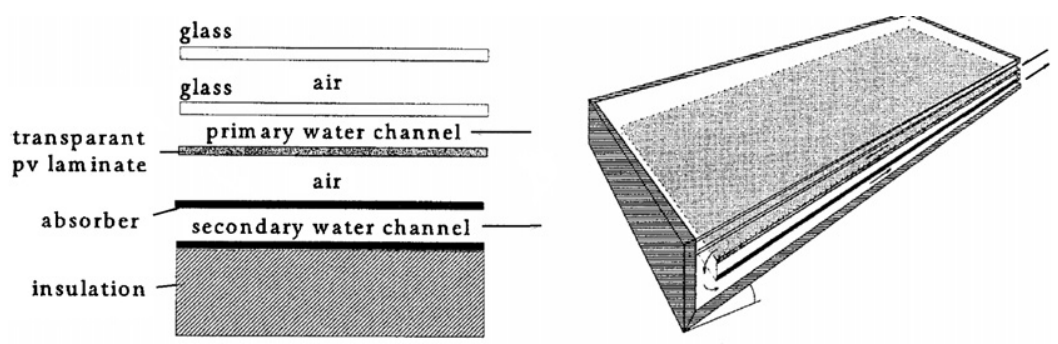

Fig. 8. Two absorber model of De Vries [43].

present calculations on the efficiency of a channel-type PVT as a function of channel width, in which also entrance effects are taken into account.

- In a review by Charalambous et al. $[15,16]$, among others an inventory was made of optimal specific flowrate, for which a substantial range of reported values was found in the literature.

- Hendrie [18] discussed the novel concept of a dual-flow PVT-liquid collector in which the incoming water flow through the collector flows directly underneath the PVlaminate, whereas the outgoing water flows directly over the PV-laminate. This design is based on the fact that the absorption of water is important only for light with wavelength longer than $0.9 \mu \mathrm{m}$. An extra glass layer is inserted providing the top boundary of the upper flow channel. A subscale prototype was built and from the measurements full scale results were predicted of over $69 \%$ thermal efficiency at zero reduced temperature and over $10 \%$ electrical efficiency at $T=20^{\circ} \mathrm{C}$.

- De Vries [43] proposed a dual-flow PVT-collector like that of Hendrie [18], but with a reversed water flow (water inlet above the PV, water exit below the PV). In addition, he proposed an additional insulating air layer between the PV and the lower channel. The design is shown in Fig. 8. While simulations showed a small increase in thermal efficiency due to this insulating air layer as compared to the design of Hendrie [18], the air layer also caused a decrease robustness of the design. Simulations showed a thermal efficiency of $66 \%$ and an electrical efficiency of $8.5 \%$. The electrical efficiency is relatively large due to the fact that the solar cells are on the cold inlet part of the collector. The thermal efficiency is $10 \%$ higher than for a corresponding sheet-and-tube collector, due to the good insulation of the high-temperature part of the collector and the larger contact area.

- Calculations by De Vries [43] show that the yearly yield of a PVT system could be raised by $2 \%$ by using a water channel underneath the cells instead of a sheet-and-tube construction. The yearly yield could be raised by another $6 \%$ for a water layer flowing over the PVT laminate instead of underneath (the design is equivalent to a double covered collector in which water is flowing through the lower channel). However, the annually averaged electrical efficiency was reduced from $6.6 \%$ to $6.2 \%$ due to the additional glass layer.

- Bakker et al. [48] built a prototype PVT collector as proposed by Hendrie [18]. However, in order to withstand the water pressure, a thick glass cover was used for the top side of the upper water channel which made the prototype very heavy, especially since the PV had a glass top- and rear cover as well in order to seal the PV from the water. Unfortunately, the glass of the PV laminate cracked due to the water pressure 
induced strain at the sides of the laminate, resulting in a rapid degradation of the a-Si cells that were used.

3.2.3.3. Heat transfer from absorber to air. In air collectors, the air is always transported through a channel. However, the thermal performance of air collectors is not as high as the performance of liquid collectors. This is due to two effects.

- Air has a thermal conductivity that is 24 times lower than for water. Since $h=N u \times k / D$ this reduces the heat transfer. This leads to the fact that for air collectors, the channel height has a large influence on the thermal efficiency. (Note that the channel height has no effect on the Reynolds number, since the decrease in flow velocity is compensated by the increase in channel width as can be seen from $\operatorname{Re}=U D / v=\Phi L / v$, in which $\Phi$ is the specific flow rate and $L$ the collector length).

- Air has a much lower heat capacity. Therefore, the flow rate in an air collector is necessarily much larger than in a liquid collector. Due to the fact that $\left\{\rho C_{p}\right\}_{\text {water }} /\left\{\rho C_{p}\right\}_{\text {air }}=4.2 \times 10^{6} / 1.2 \times 10^{3}=3.5 \times 10^{3}$, a conventional fluid flowrate of $501 / \mathrm{m}^{2} / \mathrm{h}$ for a liquid collector corresponds to an airflow of $175 \mathrm{~m}^{3} / \mathrm{m}^{2} / \mathrm{h}$, which is too high to be feasible in practice. Therefore, in practice a flowrate is used that is typically in the order of $40 \mathrm{~m}^{3} / \mathrm{m}^{2} / \mathrm{h}$.

Clearly, these effects make the heat transfer to the collector medium much more critical in air collectors than in liquid collectors. In the case of an air collector, it is therefore important to make a detailed analysis of the flow and the heat transfer in the channel.

- Prakash [235] modelled a channel-type PVT collector for the cases of both air $(100-300 \mathrm{~kg} / \mathrm{h})$ and water $(40-120 \mathrm{~kg} / \mathrm{h})$. He finds that decreasing the duct depth from 3 to $1 \mathrm{~cm}$ increases the thermal performance from $17 \%$ to $34 \%$ for an air heater $(100 \mathrm{~kg} / \mathrm{h})$ and from $50 \%$ to $64 \%$ for a water heater $(40 \mathrm{~kg} / \mathrm{h})$. For the case of $1 \mathrm{~cm}$ duct depth, increasing the flow rate from 100 to $300 \mathrm{~kg} / \mathrm{h}$ increased the thermal performance of the air heater from $34 \%$ to $51 \%$, while for the water heater an increase of $40-120 \mathrm{~kg} / \mathrm{h}$ increased the efficiency from $64 \%$ to $67 \%$. Obviously, the heat transfer is much more critical for an air collector than for a liquid collector.

- The importance of the heat transfer to the air is further underscored by measurements made by Hendrie [18], which indicated that for the first generation Spectrolab PVT collector at an average fluid temperature of $28^{\circ} \mathrm{C}$ the cell temperatures was $74{ }^{\circ} \mathrm{C}$. The heat transfer was inhibited by a badly applied encapsulant layer below the cells, which resulted in a wrinkly sheet that caused recirculation zones in the airflow through the collector, thereby reducing the area available for heat transfer. This effect was also reported by Raghuraman [109].

- Because of the critical heat transfer to the air, it is very important to model the heat transfer properly. First of all, one should be aware that for a sufficiently wide channel, the hydraulic diameter is twice the channel height [236]. Next, for laminar flow, the entrance length is often substantial. Eicker [236] presents an overview of entrance-effect heat transfer relations for air collectors, showing a variation of about $10 \%$ in average Nusselt number when integrated over the entrance length. For fully developed laminar flow she recommends to use the fixed Nusselt value of 5,4. For turbulent flow, she 
compares the Petukhov equation and the popular and more simple relation of Tan and Charters

$$
N u=0.0158 R e^{0.8}+(0.00181 R e+2.92) \exp \left[-0.03795 L_{\mathrm{c}} / d_{\mathrm{h}}\right],
$$

which she indicates to be both sufficiently accurate. The Tan and Charters relation is also used by Hegazy [123] and in the long channel limit by Sopian et al. [119] and Othman et al. [122]. Bazilian [70,292] also makes a comparison of different heat transfer relations for turbulent flow (comparing equations by Cengel, Petukhov, Brinkworth and the Dittus-Boelter equation) and finds for his configuration a variation of about $25 \%$ in the resulting Nusselt number. He concludes that the difference significantly affects the results and that the Petukhov equation is in closest correlation with his experimental findings.

A substantial amount of research on PVT air collectors has been carried out and many of them tried to improve the heat transfer to the air by means of a range of techniques.

- Loferski et al. [112] reports on a PVT-air system in which a fin is connected to the back of each PV-cell. The fins increase the surface area available for heat-exchange by a factor 4 and the thermal yield of the cells by a factor 2 over non-finned cells. The fins are connected by means of a Dow Corning RTV silicone, which is UV-resistant and can withstand temperatures of over $120^{\circ} \mathrm{C}$.

- Younger et al. [26] did measurements on a PVT-air system in which the upper side of the air channel consisted of a PV-laminate. In order to increase the heat transport from the PV laminate to the fluid he used a PV-laminate whose backside consisted of roughened Teflon with a roughness of $60 \mu \mathrm{m}$.

- Hendrie [18] suggests two PVT air designs with increased heat transfer, as depicted in Fig. 9. First, a prototype was built of a PVT-air unit in which the air was flowing through holes in the secondary absorber and impinging on the primary absorber. The design employed holes of $0.25 \mathrm{~cm}$ diameter in order to keep the internal pressure gradient below the safety limit. A thermal efficiency of $42 \%$ is found for zero reduced temperature, together with an electrical efficiency of $8.9 \%$. Another design consists of a PVT-air collector with a V-corrugated secondary absorber in which the tips of the V's
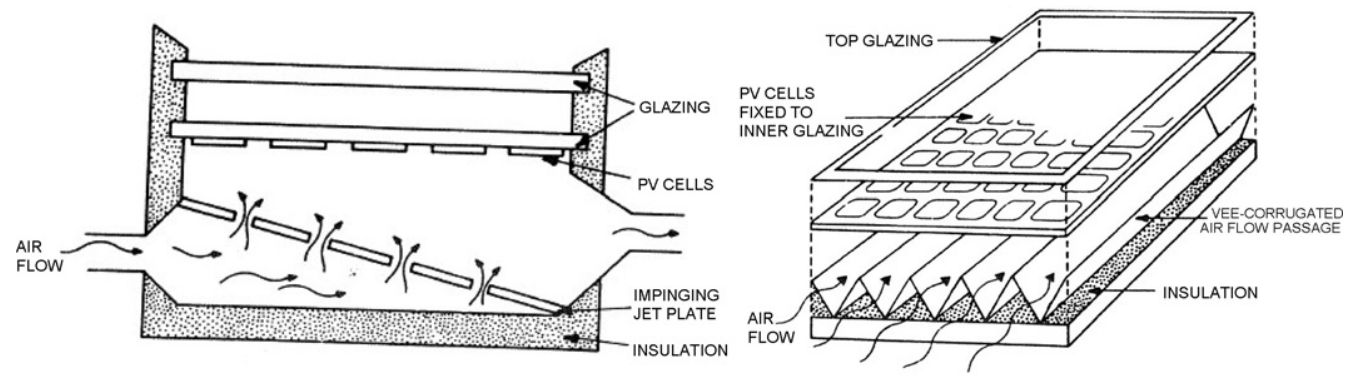

Fig. 9. PVT-concepts with increased heat transfer by Hendrie [18]. Left: impinging jet prototype, Right: V-grooved prototype. 
were in contact with the PV-laminate, so that the total heat transfer area was larger than for a channel flow, whereas the secondary absorber was heated directly by conductive contact with the cells. For this design, a thermal efficiency of $40 \%$ was found at zero reduced temperature and an electrical efficiency of $7.8 \%$.

- Tripanagnostopoulos et al. [76-79,178,295] has improved the heat transfer in his PVT air collector by inserting a blackened metal sheet at half height along the full length of the air channel. The metal sheet gets heated due to thermal radiance from the PV, and thereby adds to the effective heat transfer area, increasing his thermal efficiency from $35 \%$ to $40 \%$ at zero reduced temperature.

\subsubsection{Thermal losses}

3.2.4.1. Introduction. PVT collectors have a number of thermal losses. The more trivial ones are related to the loss through the insulation, including possible thermal bridges between the absorber and the collector casing. The most important loss mechanism is the top loss. In this mechanism, heat is lost through convection or radiation from the PVT absorber through the spacing and the PVT top cover to the ambient (in case of a glazed PVT). For unglazed PVT, the loss is simply between the PVT absorber and the ambient. In the paragraph below, an overview is presented of efforts found in the literature to increase one or more of these convective or radiative heat resistances.

3.2.4.2. Top cover. Only one case has been found in the PVT literature in which efforts were made to reduce the convective top loss of an unglazed collector.

- For an unglazed PVT collector, Hendrie [18] describes a grooved cover surface, which is coated with a low-emissivity film. Due to recirculation areas caused by the grooves, the effective surface for heat transfer can be reduced. She claims that whereas large ratios lead to large fin losses, small ratios (less than 2) are able to reduce the heat loss by $20-25 \%$. Depending on the emissivity of the surface, the thermal efficiency for zero reduced temperature is between $50 \%$ and $30 \%$.

However, the feasibility of such a scheme is doubtful. Apart from examining the thermal properties, attention should also be paid to cost and soiling, as well as possible inhomogeneous illumination of the PV. No other research was found along this direction.

Next, the radiative characteristics of the top cover are of importance. First, it would be desirable that the top cover would not transmit the radiative emission from e.g. the PVT absorber surface. For glass, the top cover is opaque for infrared radiation, which reduces the radiation losses from the PVT absorber considerably. Plastic top covers, on the other hand, often have a certain transparency for infrared. Spectra of infrared transmission for various cover materials are presented by Bansal and Sharma [237]. The relevant part of the spectral curve can be estimated by Wien's law, which gives the wavelength with maximal radiation energy density as a function of the temperature of the radiating black body: $\lambda_{\max }=2.898 \times 10^{-3}[\mathrm{~m}] / T[\mathrm{~K}]$. Since a typical absorber has temperatures in the range of $30-70{ }^{\circ} \mathrm{C}$, this corresponds with wavelengths of 9.6-8.4 $\mu \mathrm{m}$.

It would be even better if the emission of the top cover could also be reduced, e.g. by a spectrally selective coatings for the top glass that would reflect the infrared back to the absorber. However, the problem of such coatings at present is the reduced transmission in 


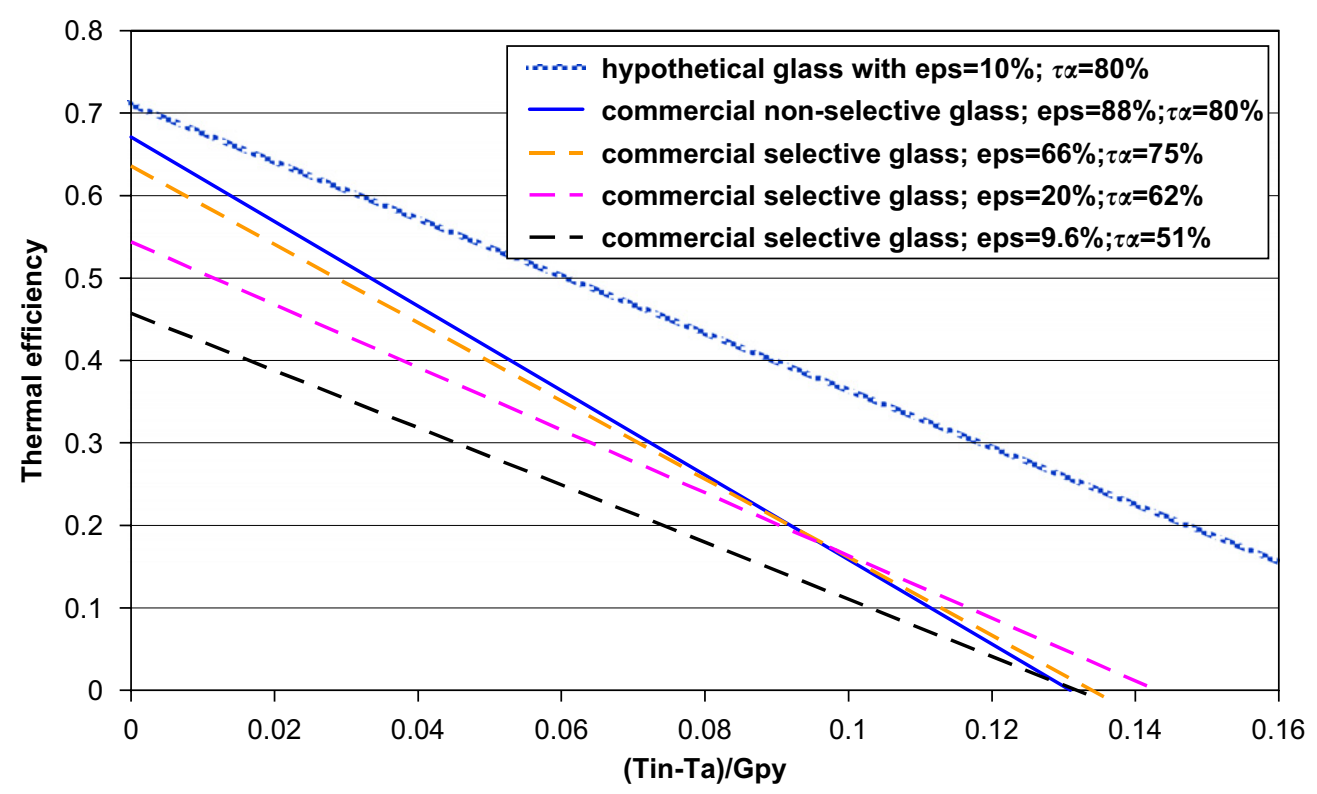

Fig. 10. The effect of spectral selectivity for a PVT absorber on the thermal performance. Also commercially available spectrally selective glazings are presented.

the solar part of the spectrum. The glass database in the LBNL program WINDOW gives $76 \%$ solar transmission at best for a glazing of $30 \%$ emissivity, while a glazing of $5 \%$ emissivity would have a transmission of at best $60 \%$. Fig. 10 indicates the effect of spectrally selective glazing; although in theory spectrally selective glazing has a substantial potential for increasing the thermal efficiency of a PVT collector, for commercially available spectrally selective glazing the transmission is too low to increase the PVT performance. Although transmission values are presently too low for PVT applications and it will be difficult to increase the transmission substantially [238], this may be promising for the future.

3.2.4.3. PVT absorber. The PVT absorber consists of a combination of a conventional solar absorber, the PV, the encapsulation material and a protective top layer. Similar to the case of the top glazing, also a reduction of the radiation losses of the PVT absorber can be achieved by making the PVT absorber top surface spectrally selective. This surface will normally be of glass, which has an emissivity of about $90 \%$. To apply a spectrally selective PVT absorber may seem trivial, since most conventional solar thermal collectors have a spectrally selective absorber. However, in practice this is very problematic. Two standard techniques exist for the creation of a spectrally selective coating:

1. A coating that is transparent for long-wave radiation and has a high absorption in short-wave radiation (e.g. a semiconductor) on top of a reflective surface.

2. A coating that is highly reflective for long-wavelength radiation and highly transparent for short-wavelength radiation on top of an absorbing surface. 
Table 1

PV emissivities (from Affolter et al. [281] and Platz et al. [229])

\begin{tabular}{lll}
\hline & Emissivity (Affolter) (\%) & Emissivity (Platz et al) (\%) \\
\hline a-Si with $\mathrm{ZnO}$ & 30 & 41 \\
a-Si with $\mathrm{SnO}_{2}$ & - & 17 \\
a-Si with ITO & 42 & $60-65$ \\
p-Si & - & 40 \\
\hline
\end{tabular}

Of course, whereas the first technique is more standard in solar thermal collectors, for PVT only the second technique is suitable. Such coatings are applied in highly efficient glazing. A problem is the limited transmission of such coatings for the solar spectrum, as indicated above for the top cover.

- Simulations on this subject have been performed by Cox and Raghuraman [23]. They concluded that the low-emission ITO layer on top of his PV-laminate increased the thermal efficiency of his PVT air collector from $34 \%$ to $39 \%$. For the calculation, they used a constant value for the emission factor of glass of $14 \%$ and an absorption of $8.3 \%$, as compared to the standard values of $86 \%$ emission and $3.4 \%$ absorption for low-iron glass. Unfortunately, the achieved improvement in thermal efficiency also resulted in a reduction of electrical efficiency from $7.3 \%$ to $6.8 \%$, largely due to the increased absorption in the glass. Cox concludes that the profitable use of a lowemissivity layer requires an emissivity of less than $25 \%$ and a solar transmissivity of more than $85 \%$. As indicated before, even now such glazing does not seem to be commercially available, since for an emissivity of $25 \%$ the highest transmission in the LBNL WINDOW library is about $73 \%$.

If the glazing on top of the PVT absorber can be left out, new options present themselves. PV may not need a top cover if protected by a thermal collector casing. Many authors have tried to use the spectrally selective properties of the PV materials themselves and the transparent top electrodes as used in thin film PV. Table 1 shows the emissivity as measured by Affolter et al. [281] and Platz et al. [229]. SDA [106] reports a value of $56 \%$ for uncoated USSC a-Si. However, since cells need to be protected from moisture, especially a-Si, it is difficult to use the spectral selectiveness of the cells in practice. This could only be done if the air layer above the cells could be sealed from the ambient. The recent market introduction of sealed thermal collectors with a gas filling between the absorber and the cover glass shows that this may be a promising line of research for the future. However, the general view is that encapsulation of the cells is required. Unfortunately, most encapsulation materials have a rather high emission.

- Affolter et al. [281] present measurements on the emissivity of EVA, which he finds to be $86 \%$.

- SDA [106] presents values for the emissivity of various hardcoats on a USSC module (Urethane, Tefzel, fibreglass). The emissivity was found to range between $81 \%$ and $92 \%$.

- Suzuki et al. [32] reports on experiments using mono-crystalline silicon cells. However, the collector surface including the cells was covered with transparent silicone rubber, 
thereby largely destroying the spectral selective properties of the surface: emittances of 0.71 and 0.86 are reported.

3.2.4.4. Spacing. Finally, the spacing between the top cover and the module could be improved. This could be done by various means, such as inner glazings or plastic films, vacuum insulation or honeycombs. Each of these techniques will be summarised below.

Multiple glazings or thin plastic foils are a way of reducing thermal losses. While for plastic foils, mechanical characteristics, thermal expansion and limited UV resistance have been a barrier, as explained previously [223], for multiple glazings the reduced transmission has been a barrier for developments along this line.

- Garg and Adhikari [126] did a parametric study for a PVT air collector. They concluded that the reduction in heat loss due to the addition of an extra cover does not justify the increased transmission loss.

- Zondag et al. [46] compared a double glazed and a single glazed PVT liquid collector. They found that for the case of domestic water heating, the increase in annual thermal performance $(35-38 \%)$ did not compensate for the loss in electrical performance $(6.6-5.8 \%)$ and the more complicated manufacturing and handling.

However, the market introduction of highly transparent glass opens new possibilities for this technique. Since such glazing have only $4 \%$ reflection loss, a double glazing with highly transparent glass gives the same reflection as a single layer of conventional low-iron glass [291].

Vacuum insulation is another way of reducing the convective loss through the spacing. However, the reduction of the convective losses by vacuum has limited effect if the radiative losses are not suppressed by means of spectrally selective coatings. Since such coatings are presently not available for PVT, the application of vacuum insulation is presently not of interest. No application of vacuum insulation has been found in the literature on PVT. Instead of vacuum insulation, also a gas filling could be used (e.g. argon, as used in energy-efficient glazing), but also here the large emission losses of the PVT absorber will limit the benefits of the additional convective resistance.

Finally, honeycombs could be used to reduce the heat transfer between the PVT absorber and the top glazing. Hendrie [18] describes an attempt of putting a honeycombstructure between the absorber and the top cover to suppress natural convection, but no experiments were done. No other examples of honeycombs have been found in the PVT literature. More recent research has pointed out the ability of honeycombs to suppress both convective and radiative losses, depending on cell size [238], and TIM materials have successfully been applied in solar thermal collectors. This could in principle present opportunities for PVT as well, provided that the translucent properties of the TIM are sufficiently good (both in terms of transmission and homogeneity) not to degrade the PV performance to much.

3.2.4.5. Reflector. A further means to increase the performance of a PVT collector is to add a planar reflector to the module. This subject has been studied experimentally, both for water and for air, by Tripanagnostopoulos et al. [79,5,6,295]. He emphasises that a diffuse reflector should be used in order to avoid inhomogeneous illumination of the PV. For water, the aluminium booster reflectors increased the performance at zero reduced 
temperature from $55 \%$ to $65 \%$ for unglazed and from $70 \%$ to $80 \%$ for glazed. For air, the performance at zero reduced temperature was increased from $38 \%$ to $60 \%$ for unglazed and from $60 \%$ to $75 \%$ for glazed.

\subsection{Electrical module efficiency}

\subsubsection{Introduction}

In addition to the reduced thermal efficiency, for a glazed PVT module, the electrical efficiency of the PVT is somewhat lower than of a PV laminate. The reduction in electrical efficiency is largely due to the additional reflection of solar radiation caused by the additional glass cover, which for good low-iron glass would result in $8 \%$ decrease in efficiency, while the use of high transmission glass would reduce this to $4 \%$. In addition, the PV power is affected by the temperature of the PVT absorber, but in practice this effect can be both positive or negative, depending on the thermal system design, both in terms of application and system dimensioning.

\subsubsection{Type of $P V$}

The electrical performance is primarily influenced by the type of PV used. In practice, only a-Si and crystalline Si have been found in the literature on PVT. The higher efficiency of crystalline Si will result in a higher electrical efficiency and a higher electrical-to-thermal ratio of the PVT than in the case of a-Si. One should be aware that the type of PV also influences the thermal performance of the PVT.

- Tripanagnostopoulos et al. [79] presents experimental measurements on PVT-liquid and PVT-air collectors for both a-Si and c-Si. He finds that at zero reduced temperature, for his PVT liquid collector, the efficiency of his c-Si prototype is 55\% and his a-Si prototype $60 \%$, while for his PVT air collector the c-Si prototype is $38 \%$ and the a-Si prototype $45 \%$. However, the electrical performance for the c-Si modules is $12 \%$ and for the a-Si it is 6\%. A higher thermal yield was also found for a-Si by Ji et al. [215]. However, in other experiments [161] a lower thermal efficiency was found for a-Si than for c-Si. Possibly, this can be explained by the range of absorptivities found for a-Si by Affolter et al. [228,281] and Platz et al. [229] as indicated before.

\subsubsection{Shading}

In conventional glazed collectors, the collector edge will cause some shading of the absorber, which does not affect the performance significantly. However, for PVT collectors this effect is much more problematic, due to the fact that shading of even one of the PV cells will strongly reduce the electrical output of the entire laminate.

- Hendrie [18] describes the second-generation production-ready PVT collectors developed together with the Spire Corporation and SDA. In these collectors, the air gap above the absorber is reduced from the conventional $4 \mathrm{~cm}$ to $1.25 \mathrm{~cm}$. In addition, also experimental PVT air designs were developed in which a gap of $1.90 \mathrm{~cm}$ was used (somewhat larger because of the higher temperature difference).

Fortunately, for unglazed PVT collectors this effect does not appear. 


\subsubsection{Temperature effect}

The efficiency of crystalline silicon cells decreases with increasing temperature. Whereas the open voltage and the fill factor decrease, the short-circuit current slightly increases. The combined effect is given by the formula:

$$
\eta_{\mathrm{PV}}=\eta_{\mathrm{PV}, T=25^{\circ} \mathrm{C}}\left(1-\beta\left[T-25^{\circ} \mathrm{C}\right]\right) .
$$

The temperature coefficient depends on the PV material used: about $0.45 \% / \mathrm{K}$ for crystalline silicon, $0.35 \% / \mathrm{K}$ for CIS, $0.25 \% / \mathrm{K}$ for CdTe and $0.2 \% / \mathrm{K}$ for a-Si [17].

For unglazed PVT, this effect is purely beneficial, since it implies that the PV is cooled compared to a conventional PV laminate. For a glazed PVT, the temperature effect will be positive when the storage is still cold, while being negative when it has heated up. However, the effect is relatively small. For the annual yield, the $8 \%$ reflection loss at the glass cover on top of the PV-laminate is often substantially larger than the temperature effect (e.g. $[23,43])$. Typically, for a glazed collector using multi-crystalline silicon, the temperature effect leads to a $2 \%$ decrease in the electrical annual yield for the case of a PVT solar heater [9]. For a-Si the effect is even lower (e.g. [220]) and can actually be positive if regular annealing results from the heating of the laminate [239].

- Zondag et al. [46] compared a conventional PV module, an unglazed PVT module and a glazed PVT module. The average annual electrical efficiency was found to be $7.2 \%$, $7.6 \%$ and $6.6 \%$ respectively. Since a glass with a transparency of $92 \%$ was used in the calculations, the reduction in electrical performance for the glazed PVT as compared to the conventional PV laminate is exactly what one would expect from the additional reflection losses, which means that for the glazed PVT the additional temperature effect cancelled over the year, while for the unglazed PVT the temperature effect was positive.

- Krauter [64-66] has been developing an unglazed integrated solar home system, in which a PV laminate is connected to a triangular water tank. The tank serves to cool the PV by means of an 'extended heat capacity'. Typically, at high irradiance a PV temperature reduction of about $20{ }^{\circ} \mathrm{C}$ is reported relative to a conventional solar home system, which leads to a $9-12 \%$ increase in electrical yield, depending on the stratification. The stratification in the tank causes a temperature difference of about $6{ }^{\circ} \mathrm{C}$ between the upper and the lower PV module. In a later prototype the battery storage is placed at a cooled triangular space at the centre of the storage and the PV is shifted to the lower part of the tank to improve PV performance.

- Chow (2005) calculated the electrical performance of a thermosyphon PVT collector with the PV at the high end and at the low end of the absorber. For the colder low end, he found a 3\% higher electrical efficiency.

- Grammer Solar built a PVT air module in which the PV-part is only present in the lowtemperature entrance of the collector, while only the high-temperature part of the collector is glazed. The purpose of this collector is the preheating of ventilation air, and therefore the air passes through the collector only once, making this design especially effective.

- Naveed et al. [240] examined a PVT air system in which PV was connected to an unglazed transpired collector. It was found that a temperature reduction of $3-9{ }^{\circ} \mathrm{C}$ resulted in an improved electrical performance, allowing a reduction in PV area from 25 to $23 \mathrm{~m}^{2}$. 


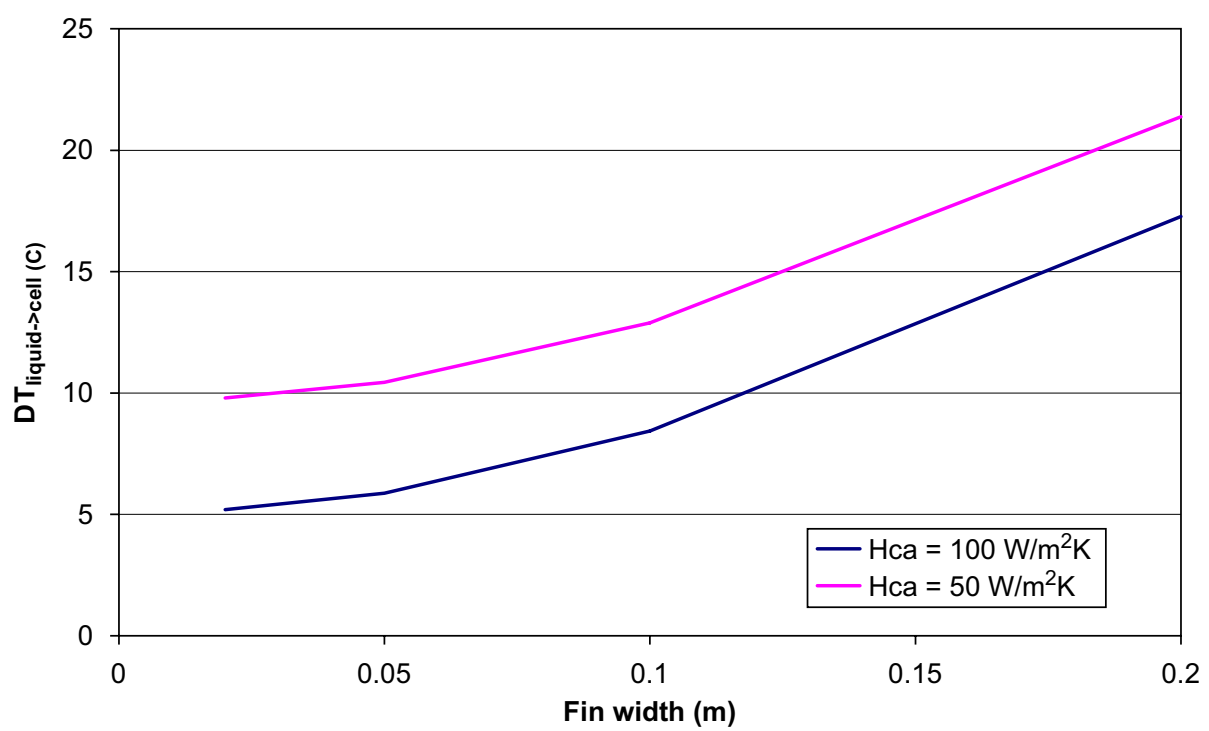

Fig. 11. Effect of tube spacing on average absorber temperature $\left(\mathrm{Gpy}=800 \mathrm{~W} / \mathrm{m}^{2}, \tau \alpha=0.8\right)$. The figure is calculated from the Hottel-Whillier model adapted for PVT as described in Zondag et al. [45]. $H_{\text {ca }}$ is the heat transfer coefficient between cells and absorber.

Of course, thermal resistance between the PV and the collector fluid will increase the PV temperature, with negatively affects both the electrical and the thermal performance. Fig. 11 indicates the effect of the tube spacing on the average absorber temperature, clearly showing that wide tube spacing will lead to lower electrical performance. The figure also indicates the effect of the thermal resistance between PV cells and absorber, which can be substantial.

\subsubsection{Temperature homogeneity}

PV-cells that are connected in series have to operate at the same current, while PV-cells that are connected in parallel have to operate at the same voltage. The IV-characteristics depend on the temperature, however. Since a temperature gradient exists over the PVT, not all cells may be able to operate in their maximum power point at the same time. This effect was examined experimentally by Smith et al. [111], who measured the electrical performance of series connected cells and found no effect of the temperature gradient, which he varied between 3.9 and $38^{\circ} \mathrm{C}$. Numerically, the effect was examined by Lambarski [241], who found only a very small effect of the temperature in the case of series connection $(<1 \%)$, but a large effect in the case of parallel connection of about $17 \%$ loss. He concluded that series strings may be represented by their average temperature and that cells at different temperatures should be connected in series and not parallel. The case of series connection was also examined numerically by De Vries [43], who found no effect of the temperature gradient.

\subsubsection{Cover reflection}

The absorbance of a PVT collector is proportional to the transparency of the covers over the collector. This has implications for the thermal absorbance as well as the electrical 
performance of PV underneath the cover layers. The electrical efficiency can be determined approximately with the formula $\eta_{\mathrm{el}}=\tau \eta_{\mathrm{PV}}$ in which $\tau$ represents the cover transmission. Typical values for the transmission are $92 \%$ for low-iron glass and $96 \%$ for highly transparent glass.

In addition, Nagano et al. [218] warns that in his experiments during the winter the electrical efficiency was degraded by $9 \%$ due to condensation on the glass cover. A similar observation is reported by $\mathrm{He}$ et al. [97], indicating that when the weather turned cold, condensation frequently appeared on the front glazing in the early morning for about an hour, decreasing both thermal and electrical efficiency.

\subsection{Reliability}

\subsubsection{Introduction}

Although reliability aspects are very important for the development of PVT, these issues have only received very limited attention in the literature. In addition, no dedicated guidelines for PVT reliability testing exist today. Although the testing standards for PV laminates (IEC 61215) and solar thermal collectors (EN-12975) handle most of the relevant aspects, a number of specific issues exist for PVT that are not covered by these tests. A guideline for PVT testing including reliability issues has been drafted as part of the PVCatapult project [61]. Over the coming 2 years, this guideline will be elaborated further as part of the present IEA task 35 on PVT.

\subsubsection{Stagnation temperature}

In a conventional thermal collector system, the stagnation temperature is likely to occur several times a year during some hours when the storage is completely loaded. Since the heat is not drawn off from the collector in these cases, high module temperatures will result. Typical stagnation temperatures in a conventional thermal collector are around $180-200{ }^{\circ} \mathrm{C}$.

For unglazed PVT-systems these stagnation conditions are not a problem, as the temperature is the same as that for a badly ventilated PV module. For example, Sudhakar and Sharon [230] report a stagnation temperature of $75^{\circ} \mathrm{C}$ for their unglazed PVT module.

However, for glazed PVT systems the situation is different. Fortunately, the stagnation temperature for a covered PVT system is lower than that of a convectional collector system, due to the lower absorption and the fact that the absorber surface is not spectrally selective. Nevertheless, stagnation temperatures of around $130{ }^{\circ} \mathrm{C}$ should be expected [51], which is much higher than the temperature encountered by conventional PV laminates. Under these high-temperature conditions, deterioration of the encapsulation material or the top film might occur.

- Affolter et al. [280] indicates that EVA becomes doughy at $70{ }^{\circ} \mathrm{C}$ but that a stable elastomer up to $130^{\circ} \mathrm{C}$ can be created by adding a curing additive. For temperatures over $130{ }^{\circ} \mathrm{C}$ he indicates that the EVA looses its mechanical properties and could become brown under UV exposure, reducing the absorption in the PV. He indicates that a possible solution might be to go back to encapsulation with silicone resin, which was the main encapsulation material before 1980. This material has a very high temperature resistance of -55 to $200{ }^{\circ} \mathrm{C}$ and the cost has gone down over the years, but the handling is more difficult. He also suggests to equip the PVT system with a control system to avoid high temperatures. 
- Komp warns that, for PVT applications, silicone encapsulation should be preferred over EVA [242]. In addition, he warns that for PVT devices with a concentration factor over 2, stagnation may lead to melting of the solder on the interconnecting wires. In a later paper, Komp [34] warns that he had trouble with delamination of the silicone layer in his first PVT prototypes after operating for a year under stagnation conditions, but he indicates to have remedied this by using a much thinner silicone top coating.

Other solutions for this problem, apart from lowering the stagnation temperature, were not found in the literature.

A similar problem can occur when Teflon is used for covering the PV-cells. Hendrie [18] reports on a PVT-system in which the Teflon inner encapsulant film turned out not to be stable at the operating temperatures and outgassed. This reduced the optical transmission of the cover by $10-15 \%$.

Although the interest for this subject has been limited according to the literature, stagnation temperature resistance is an important issue that needs more attention.

\subsubsection{Thermal shock}

When the pump of the PVT-system is started, cold collector fluid might be inserted into a hot stagnating collector. In this way, large temperature differences are created across the PV-laminate. The corresponding thermal stresses should not be able to damage or break it. This is a standard test in the EN 12975, but no literature references were found on the application of this test on PVT modules. However, internal thermal shock tests carried out at at ECN, in which cold water was inserted in a hot PVT module $\left(120^{\circ} \mathrm{C}\right)$ of the directly laminated sheet-and-tube type, did not show any degradation.

\subsubsection{Electrical insulation}

As indicated before, electrical insulation between the PV and the metal absorber should be sufficiently good to avoid safety issues. It is therefore important that the electrical resistance between the PV and the metal rear should be measured and found in accordance with IEC 61215.

\subsubsection{Other reliability tests}

With respect to other reliability issues, such as hot spots, thermal behaviour of bypass diodes or UV exposure, as described in IEC 61215, no experimental results were found in the PVT literature. Nevertheless, these are important issues for further development of PVT.

\subsection{Conclusion on module aspects}

Prototype PVT collectors are often suffering from 'infants diseases' such as insufficient heat transfer due to insufficient thermal contact between the PV and the thermal absorber. However, this problem can be solved by applying thin adhesive layers that have a sufficiently high thermal conduction. This also calls for attention to the electrically insulating layers between the cells and the absorber, whose thermal resistance should be minimised. Furthermore, absorption of PVT absorbers can be raised due to the use of PV that is optimised also for solar IR absorption, while the thermal insulation can be improved by using e.g. double layers of highly transparent glazing. Highly transparent 
glazing is especially relevant for PVT because it also improves the electrical performance. For the future, spectrally selective coatings for PVT absorbers may become of interest, but this requires further efforts in the development of suitable coatings. For PVT liquid collectors, the sheet-and-tube design is very reliable and has a good heat transfer, but channel plate constructions may provide interesting ways of further increasing the heat transport, provided that the channels are made sufficiently thin. For PVT air collectors, attention should be paid to improved heat transfer devices. These issues require further R\&D efforts.

A direct consequence of the improved absorption in combination with reduced heat loss will be higher stagnation temperatures. This demands continued efforts to find stagnationresistant encapsulation materials.

Finally, it is very important that test standards, including reliability tests, are established to be able to assess the performance and the reliability of PVT collectors more carefully and to allow better comparison of the performance testing results. A guideline for PVT testing including reliability issues has been drafted as part of the PV-Catapult project [61].

\section{Module aspects ventilated BIPV with heat recovery}

\subsection{Introduction}

PV-Thermal air systems exist in two types. They can consist of air collector modules, or they can be constructed as part of the building shell, through applying an air gap between the wall and the PV-laminate. The majority of the projects involving PV-air consists of building-integrated PV-air systems. While PVT air collectors have been discussed in the previous section, the present section will be concerned with BIPVT.

Similar to PVT air collectors, also for BIPVT the heat transfer to the air is crucial to the thermal performance. Widely different thermal efficiencies are reported for air-systems: from $14 \%$ up to $60 \%$. This is due to the fact that the heat transfer can be increased strongly by increasing the air velocity. Since this is a critical parameter, much effort has been put in its correct measuring and modelling.

\subsection{Thermal efficiency}

\subsubsection{Natural convection}

In the case of building-integrated PVT air systems, the airflow along the PV is often driven by natural convection.

- Within the EU supported project on cost effective PV cladding for commercial buildings, a ventilated PV-wall was designed [144]. The resulting $1.4 \mathrm{kWp}$ prototype consists of a curtain wall of semi-transparent PV, in front of the facade construction, over a height of two storeys. The heated air behind the PV rises due to natural convection, thereby drawing air out of the building through windows and louvres, which effect is used to assist the building ventilation. The cavity between the PV and the facade construction has a width of $700 \mathrm{~mm}$. Shaw et al. [147] indicate that it is necessary for such applications to provide a continuous height of at least four metres to generate sufficient buoyancy. A prototype ventilated PV facade was tested at the PASSYS test 


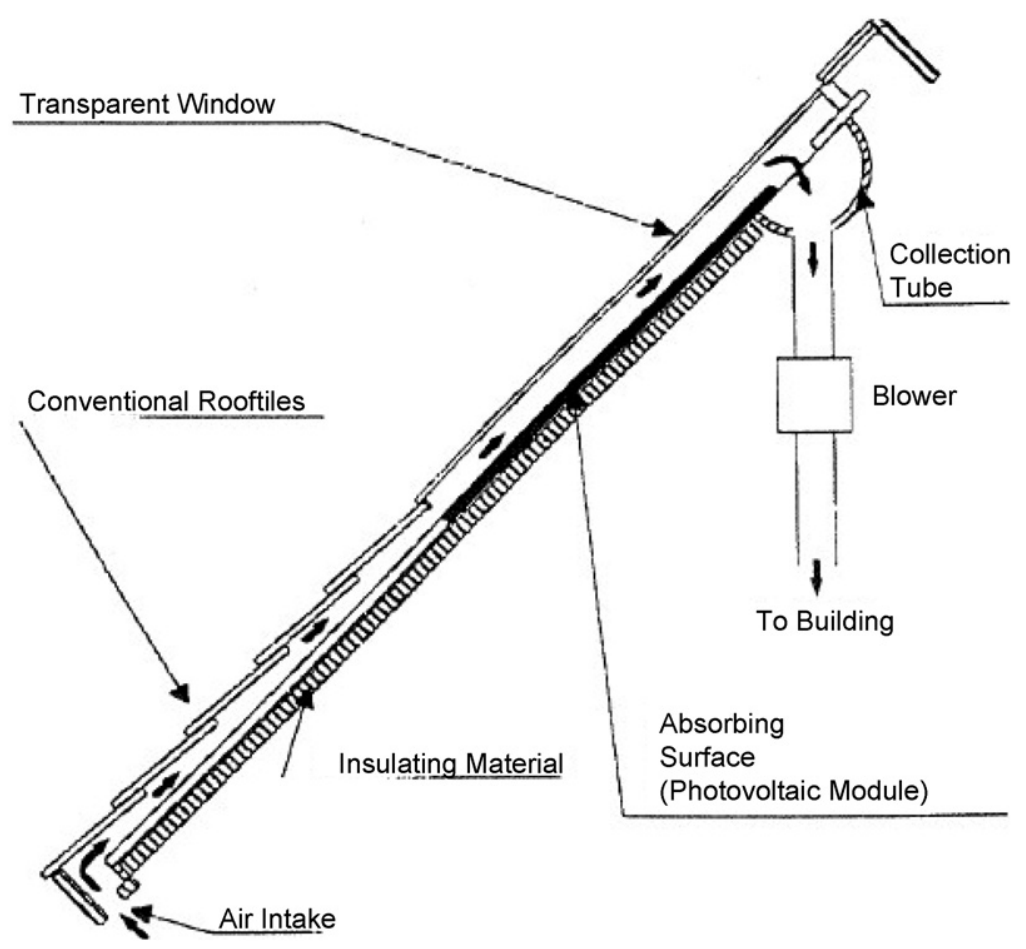

Fig. 12. PV Hypri roof system by Dunlop et al. [165], mounting configuration (a).

cell at the BRE, UK [146]. Airflow rates were found in the range of $0.04 \mathrm{~m} / \mathrm{s}$ for an irradiance of about $80 \mathrm{~W} / \mathrm{m}^{2}$ to $0.15 \mathrm{~m} / \mathrm{s}$ for an irradiance of $650 \mathrm{~W} / \mathrm{m}^{2}$.

- Bollo et al. [243] examined a solar chimney (duct depth $0.4 \mathrm{~m}$ ) for different configurations. Among others, he investigated: (a) PV on the front surface and (b) low-emittance glass on front surface and PV within the air channel, $0.05 \mathrm{~m}$ below the front surface, in both cases for natural convection and the chimney under $37^{\circ}$. It was found that for these cases, in configuration (b), a substantially higher-temperature increase was found over the height of the solar chimney, but also that the electrical efficiency was reduced by $35 \%$ due to the reduced transmittance of the low-emissivity glazing and the high PV temperature that reached a maximum of about $100{ }^{\circ} \mathrm{C}$.

- Within the PV HYPRI project, a naturally ventilated roof-integrated PV module is investigated as indicated in Fig. 12, in which two mounting options are examined: (a) with the airflow between a polycarbonate top cover and the PV laminate or (b) with the airflow between the unglazed PV laminate and the roof [165]. However, for option (a), a serious decrease in electrical performance was expected due to transmission losses caused by the additional cover [168], which made (b) the preferred option. For this case a prototype of $1.6 \mathrm{~m}^{2}$ was built and 2 different PV laminates were tested: a standard type and a semi-transparent module. For the standard PV module type with a packing factor of $85 \%$, under an irradiation of $380 \mathrm{~W} / \mathrm{m}^{2}$ a flow velocity of $0.4 \mathrm{~m} / \mathrm{s}$ resulted and $25 \%$ thermal efficiency was found, together with $11 \%$ electrical efficiency. The semitransparent module, which had a lower module-packing factor of $72 \%$, was found to 
give a higher efficiency of $43 \%$ thermal, together with $10 \%$ electrical [165]. In addition, the effect of longitudinal fins was investigated, which turned out to reduce the flowrate somewhat but also to generate a more uniform velocity distribution in the gap; the overall result of these two effects was expected to be positive [166]. Furthermore, Sandberg indicated that, if the PV covers only part of the façade, the ideal location of the PV is at the lower end of the air channel, because this results in a higher column of heated air and therefore a higher natural convection flow.

- Research on the resulting heat transfer, thermal efficiency and flow rate for naturally ventilated PV roofs and facades has been carried out at the Gävle University, as part of the projects PV-HYBRID-PAS, PV-HYPRI and PV-Cool-Build. Sandberg and Mosfegh [175] present relations for the flow velocity and the heat transfer for turbulent natural convection flow through the airgap. They indicate that the turbulent case is the most relevant one, since laminar flow occurs only for very low irradiance or very thin airgaps. The equations are presented in a general form, a generalised expression is used for the effective friction length and a geometrical shape factor is presented for the length of the duct above and below the PV area. For the special case of PV uniformly distributed over the facade area, the following relations result:

Friction-constrained turbulent flow ${ }^{2}$ :

$$
\dot{m}=\rho\left(\frac{\beta q / 2 \rho C_{p}}{w \lambda} g \sin \varphi\right)^{1 / 3} w d
$$

inlet/outlet-constrained flow:

$$
\dot{m}=\rho\left(\frac{\beta q H / \rho C_{p}}{\left(1 / A_{\text {in }}\right)^{2}+\left(1 / A_{\text {out }}\right)^{2}} g \sin \varphi\right)^{1 / 3},
$$

where $\mathrm{A}_{\text {in }}$ and $\mathrm{A}_{\text {out }}$ are the entrance and exit areas, $\mathrm{d}, \mathrm{w}, \mathrm{H}$ are the channel depth, width and height, respectively, $\lambda$ is the friction factor and $\mathrm{q}$ is the incoming heat flow.

Tests were carried out in which the theoretical results were validated with experiments. It was found that whereas for constrained flow the results were very good, for the case of both ends open the measured flow rate was found to match for narrow channels, while for wide channels the actual flow was found to be about $20 \%$ lower than the calculated value.

- Extensive research on airflow and heat transfer in PV-ducts has been carried out at the Cardiff University. Brinkworth et al. [169] describes experimental and numerical work on a PV clad wall. He calculated a base case with a duct height of $5 \mathrm{~m}$ and a duct width of $120 \mathrm{~mm}$, for facade integration for a sunny day in Cardiff (peak irradiance for vertical surface $620 \mathrm{~W} / \mathrm{m}^{2}$ ). Increasing the height of the duct increases the temperature rise and thereby the buoyancy induced flow rate, increasing from $0.2 \mathrm{~m} / \mathrm{s}$ at a height of $1 \mathrm{~m}$, to a fixed value of $0.4 \mathrm{~m} / \mathrm{s}$ for heights over $30 \mathrm{~m}$. By increasing the duct width from

\footnotetext{
${ }^{2}$ When using the results of Sandberg and Mosfegh [175], note that the density is accidentally missing in the definition of $B$ (e.g. compare to [166]).
} 
60 to $260 \mathrm{~mm}$, the mass flow increases and the PV temperature is somewhat reduced. No further gain is obtained by increasing the width over $250 \mathrm{~mm}$. Brinkworth et al. [171] calculates the natural convection flowrate from

$$
\dot{m}^{3}=\frac{2 S\left(\rho_{0} A_{\mathrm{c}}\right)^{2} g L \beta Q_{\mathrm{g}} \sin \theta}{C_{p}\left(k_{f 1}+k_{f 2}+f(L / D)\right)},
$$

where $\mathrm{k}_{\mathrm{f} 1}$ and $\mathrm{k}_{\mathrm{f} 1}$ are the friction factors of the entrance and exit, $\mathrm{S}$ is a stratification parameter $\left(S=0.5\right.$ for a linear temperature increase) and $Q_{g}$ is the thermal gain. In combination with the appropriate Nusselt relation, it is now possible to calculate the flow rate and the heat gain by means of iteration. This method has been adopted by several other authors, such as Guiavarch and Peuportier [208] and Bazilian [213]. In addition, for natural convection combined with wind, Brinkworth et al. [171] derive the following:

$$
m^{3}=\frac{\left(\rho_{0} A_{\mathrm{c}}\right)^{2}\left(2 S g L \beta Q_{\mathrm{g}} \sin \theta / C_{p}+m\left(C_{P_{1}} W_{\text {in }}^{2}-C_{P_{2}} W_{\text {out }}^{2}\right)\right)}{\left(k_{f 1}+k_{f 2}+f(L / D)\right)},
$$

where $C_{P_{1}}$ and $C_{P_{2}}$ are the wind pressure coefficients at the inlet and the exit, and $W$ is the wind speed. Based on experimental work, correlations for the friction factor $\mathrm{f}$ are presented. More information on friction coefficients and Nusselt relations is provided by Brinkworth [170]. The importance of wind effects was also stressed by Infield [244], based on measurements at the Mataro library, and by Versluis et al. [161] .

- For the Mataro PVT facade project, Eicker and Gross [180] carried out measurements of a test facade at the University of Stuttgart. For natural convection, the measurements indicated that, with the irradiance increasing from 200 to $1000 \mathrm{~W} / \mathrm{m}^{2}$, the air velocity behind their $2.75 \mathrm{~m}^{2}$ test facade increased as shown in Fig. 13, while the thermal efficiency increased from $5 \%$ up to $30 \%$. Under natural convection conditions, the velocity of the flow strongly depends on the friction in the air channels, which was found to be substantially higher than the calculated literature values; the high resistance found was attributed to the perforated metal sheets at the in- and outlet; if wire meshes would have been used it was estimated that an air velocity of $0.4 \mathrm{~m} / \mathrm{s}\left(79 \mathrm{~m}^{3} / \mathrm{m}^{2} / \mathrm{h}\right)$ could have been obtained easily. Although the Reynolds numbers for free convection flow corresponded to the transition from laminar to turbulent, smoke visualisation indicated the laminarity of the flow under all natural convection conditions. Also forced convection was applied. For this case, thermal efficiencies up to $60 \%$ were found at a flow velocity of $0.7 \mathrm{~m} / \mathrm{s}\left(137 \mathrm{~m}^{3} / \mathrm{m}^{2} / \mathrm{h}\right)$.

\subsubsection{Mixed and forced convection}

The case of forced convection applies to some of the building-integrated systems and all of the PVT air collectors. Since the airflow rate strongly affects the thermal performance, several authors have argued that it is worthwhile to consider forced ventilation also in facades [292].

- As part of PV-HYBRID-PAS, studies were carried out into the characterisation of PVT building elements. A reference system was investigated consisting of a sample wall equipped with 2 opaque polycrystalline silicon modules of $95 \mathrm{Wp}$, connected to a 


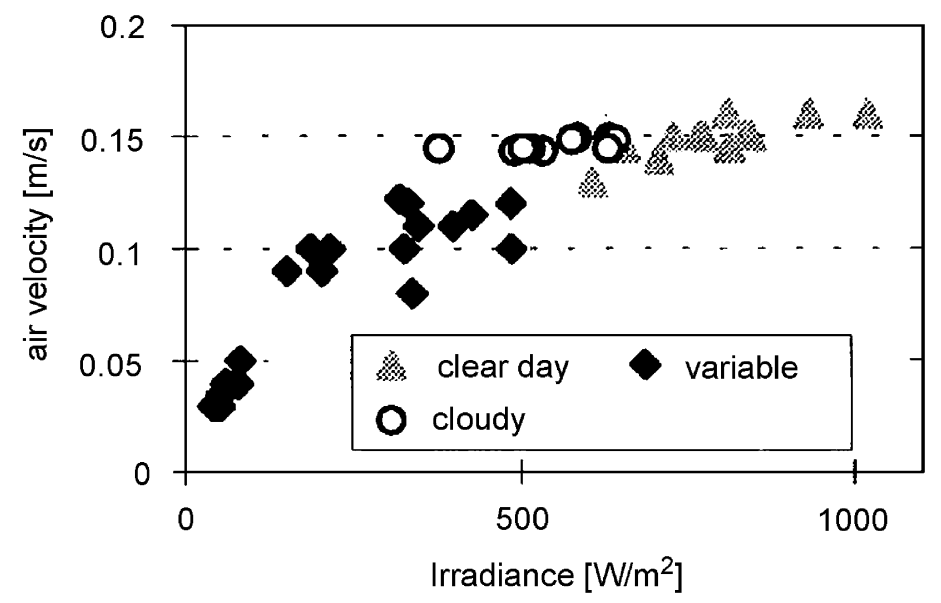

Fig. 13. Natural convection air speed in PV facade as a function of irradiance as measured by Eicker and Gross [180].

PASLINK test cell. Between the PV and the opaque insulated wall is an air cavity that is mechanically ventilated. The width of the cavity can be varied but a default setting of $50 \mathrm{~mm}$ is used. Seven test sites in Europe were involved in the parallel testing of the setup described. The results of the measurements are presented in the form of $U$ and $g$ values ( $U A$ and $g A_{\text {trans }}$ to describe the heat flows to the room, $U A_{\text {vent }}$ and $g A_{\text {vent }}$ to describe the heat flows to the ventilation flow). The method is further described by Versluis and Van Dijk [162], showing that a dynamical thermal network model based on these quantities describes the thermal performance very well. Most test reports also show the dynamical effects (thermal inertia), which are clearly important. In the test report by ITW, Pfluger and Twerdy [290] also show measured temperature profiles over the width of the $100 \mathrm{~mm}$ air cavity, showing two distinct boundary layers: one at the PV side and one at the rear side of the cavity. In the final report, Wouters and Vandaele [245] focus on the results of thermal experiments in which the heating was carried out by heating foils instead of solar irradiance; a technique that was adopted in order to increase the accuracy of the measurements. These measurements are described in more detail in an annex report [246]. The external wind speed was varied from no external fan to $4 \mathrm{~m} / \mathrm{s}$, reducing the thermal efficiency from $67 \%$ to $38 \%$ (although measurements under outdoor conditions later indicated a smaller effect). An increase in the air velocity in the cavity from 0.9 to $1.7 \mathrm{~m} / \mathrm{s}$ resulted in an increase in thermal efficiency from $61 \%$ to $74 \%$ for the case without external fan and a cavity width of $40 \mathrm{~mm}$. Similarly, keeping the volume flow constant, a reduction from the cavity width from 100 to $40 \mathrm{~mm}$ increased the thermal efficiency from $67 \%$ to $74 \%$ for the case without external fan. An additional front cover increased the thermal efficiency from $38 \%$ to $81 \%$ for the case of $4 \mathrm{~m} / \mathrm{s}$ external wind condition (substantially better than the $68 \%$ for no external fan). Aluminium heat fins increased the efficiency from $68 \%$ to $70 \%$ for the case without external fan, but from $38 \%$ to $50 \%$ for the case with $4 \mathrm{~m} / \mathrm{s}$ external wind speed. One of the conclusions from these results was that the external flow pattern had a very large impact on the thermal efficiency, that the thermal efficiency of a ventilated PV component could therefore not be considered as a constant but should take into account 
outdoor conditions, and that it would be difficult to develop a robust design procedure since the prediction of flow patterns is not sufficiently reliable.

- In the Mataro library, $7900 \mathrm{~m}^{3} / \mathrm{h}$ of ventilation air is drawn in through a ventilated PV facade with dimensions of $H \times W \times D=6.5 \mathrm{~m} \times 36 \mathrm{~m} \times 0.14 \mathrm{~m}$ [244]. The resulting flow velocities are in the order of $0.5 \mathrm{~m} / \mathrm{s}$ and a thermal efficiency of $30 \%$. The report indicates that optimal dimensions of the airgap would have been $H \times W \times D=8 \mathrm{~m} \times$ $36 \mathrm{~m} \times 0.03 \mathrm{~m}$, resulting in a velocity of $3 \mathrm{~m} / \mathrm{s}$ and an efficiency of $45 \%$. The low velocity means that natural convection has an important influence. The effect of mixed convection is calculated based on the following set of equations (see also $[191,236])$ :

$$
\begin{aligned}
& R e_{\text {free }}=\sqrt{G r / 2,5} \quad N u_{\text {lam }}=0.664 \operatorname{Re}^{0.5} \operatorname{Pr}^{0.33}, \\
& R e_{\text {forced }}=U L / v, \quad N u_{\text {turb }}=\frac{0.037 \operatorname{Re}^{0.8} \operatorname{Pr}}{1+2.443 \operatorname{Re}^{-0.1}\left(\operatorname{Pr}^{0.67}-1\right)}, \\
& \operatorname{Re}=\sqrt{\operatorname{Re}_{\text {free }}^{2}+\operatorname{Re}_{\text {forced }}^{2}}, \quad N u=\sqrt{N u_{\text {lam }}^{2}+N u_{\text {turb }}^{2}} .
\end{aligned}
$$

The original air filters were found to cause a large flow resistance and were replaced. In addition, it was found that the effect of wind was substantial; for an easterly wind the cavity air was even forced in the downward direction.

In order to facilitate the design of PVT facades, a model for the thermal performance of the PVT facade was developed [186-189,244,247], based on the conventional $U$ - and $g$-values of glazings. $U_{\text {trans }}$ and $g_{\text {trans }}$ are defined for the transmission through the semitransparent facade, as well as $U_{\text {vent }}$ and $g_{\text {vent }}$ for the heat transfer to the cavity air, similar to the approach in the PV-Hybrid-PAS project. Equations for the calculation of these quantities are presented by Infield et al. [189,247].

- Nagano et al. [217,218] did experiments with 6 different PVT modules of $1.4 \mathrm{~m}^{2}$ each, which he tested as hybrid wallboards under an inclination of $80^{\circ}$. He prefers wall integration over roof integration to avoid the problem of snow coverage. For the PV, he used a-Si or crystalline silicon with glass or teflon PV cover, while his modules were either glazed or unglazed. The forced flow rate was $20 \mathrm{~m}^{3} / \mathrm{h}$ per fan, which gives a specific airflow of about $45 \mathrm{~m}^{3} / \mathrm{m}^{2} / \mathrm{h}$. He reported efficiencies in the range of $29-37 \%$ for the glazed modules and $20-22 \%$ for the unglazed modules.

- Bazilian [12,211] presents measurements on an experimental ventilated BIPV test site in Sydney, Australia, containing 20 solar tile modules, of which $20 \%$ is fitted with a heat recovery unit. Through an air gap of $0.15 \mathrm{~m}$, the module is cooled by means of forced convection (flowrate $0.35 \mathrm{~m} / \mathrm{s}$, corresponding to $110 \mathrm{~m}^{3} / \mathrm{m}^{2} / \mathrm{h}$ ), which results in a thermal efficiency of about $30 \%$. Further test results [211] show that at an irradiance of $800 \mathrm{~W} / \mathrm{m}^{2}$ the temperature of the ventilated PV is about $7^{\circ} \mathrm{C}$ lower than for the nonventilated PV. On an annual basis, the reduced temperature leads to a $4 \%$ increase in electrical yield for the ventilated PV (for the case of c-Si). In addition, Bazilian [212,292] did experiments on a roof-integrated-ventilated PV at a test facility at the UNSW. The 
dimensions of the duct are $H \times W \times L=0.15 \mathrm{~m} \times 0.6 \mathrm{~m} \times 2.4 \mathrm{~m}$. The modules were subject to ventilation by means of an energy-efficient eco-fan (flow rate $264 \mathrm{~m}^{3} / \mathrm{h}$, power consumption $6 \mathrm{~W}$ ), aided by the buoyancy in the duct, which turned out to have a significant effect [292]. In natural convection measurements, with the fans removed to increase the inlet area, a peak duct velocity was found of $0.12 \mathrm{~m} / \mathrm{s}$ in winter, which for the summer would be about $0.17 \mathrm{~m} / \mathrm{s}$ [292]. He found that the ratio of thermal over electrical production was about 2 for the c-Si modules and 3.5 for the a-Si modules.

In addition, one should be aware that the heat transfer between the PV and the airflow is also often affected by details of the inlet or framing of the collector.

- Direct numerical simulations on the detailed fluid flow have been carried out by Bazilian et al. [71], investigating the effect of the PV frame edges on the airflow, which he found to cause recirculation areas. He found that the size of these recirculation zones could be reduced by means of airfoils attached to the frame.

- Gandini et al. [248] carried out a DNS study on the airflow distribution within a facade, where he found strong localised turbulence due to the inlet and an inhomogeneous heat transfer.

\subsubsection{Techniques to increase the heat transfer}

In order to increase the heat transfer to the flow, various techniques have been investigated.

- Tripanagnostopoulos et al. [178] did experiments on a forced ventilation PV-air system, with a channel of $15 \mathrm{~cm}$ width. He improved the efficiency by inserting metal fins of 1.5 and $4 \mathrm{~cm}$ to the rear surface, by inserting metal tubes of $15 \mathrm{~cm}$ diameter and by inserting a blackened metal sheet at half height along the full length of the air channel. While the fins had a relatively small effect, the effect of the tubes and the metal sheet was higher. However, because of the additional cost and pressure drop associated with the fins and the tubes, the thin metal sheet was preferred as heat transfer enhancement. In addition, roughening of the rear side of the cavity was considered a low-cost way of obtaining a further small increase in thermal and electrical efficiency, but it was indicated that, in contrast to the thin metal sheet, rear surface roughening does not avoid undesirable heat transfer to the building. Tonui and Tripanagnostopoulos [249] present efficiency curves for the cases with a thin metal sheet and with fins, as compared to the reference case. They indicate $25 \%$ efficiency for the reference, versus $28 \%$ for the thin metal sheet and $30 \%$ for the fins. They argue that the fins may be more suitable for a cold climate, whereas for a hot climate the thin metal sheet is more suitable because of the lower undesirable heat transfer to the building.

- Crick et al. [146] glued aluminium fins to the back of a PV module in their naturally ventilated facade, which they found to increase the heat transfer considerably.

- Kelly and Strachan [250] present a literature overview of the possible heat transfer enhancements to a PV facade. They report heat transfer enhancements of $600 \%$ for shrouded pin fins and $400 \%$ for a transverse ribbed surface with vortex generators.

- Hodge and Gibbons [251] summarised various techniques of increasing flat-plate heat transfer, discussing the effects of hole geometries, rib turbulators and dimples. 


\subsection{Electrical efficiency}

The electrical efficiency of ventilated PV is better than of non-ventilated PV, due to the lower PV temperatures.

- Chow et al. [252] calculate the electrical performance for integrated BIPV, ventilated PV and PVT, with monocrystalline cells, for a hotel in Macao. They find that the electrical yield is largest for the ventilated PV and lowest for the BIPV, but the differences are very small. While the ventilated PV is in their simulation cooled by both buoyancy and wind effects in the duct behind the PV, for the PVT case the cooling is only supplied by buoyancy, which results in a $40 \%$ lower flow rate and a slightly higher average temperature for the PVT. For Hong Kong, Ji et al. [214] find a similar conclusion.

- A study for forced convection of PVT slates was carried out by Kropf [136]. He did calculations over the flow range of $14-108 \mathrm{~m}^{3} / \mathrm{m}^{2} / \mathrm{h}$ for a duct width of $6 \mathrm{~mm}$. For $108 \mathrm{~m}^{3} / \mathrm{m}^{2} / \mathrm{h}$, he finds an increase in electrical yield of about $10 \%$ as compared to nonventilated PV.

- Guiavarch and Peuportier [209] compare the electrical yield of non-integrated PV, integrated PV without air gap, ventilated PV and a ventilated PV with heat recovery. The PV without air gap has the lowest performance, of about $7 \%$ less than the ventilated PV for Paris, and 8\% less for Nice. The differences between the ventilated PV and the PVT application are relatively small (the PVT yield is typically $1 \%$ less).

In the literature, some cases were found in which the ventilated PV was covered by an additional glazing, but this may lead to relatively high PV temperatures [114,243].

\subsection{Reliability}

No special reliability issues appear for ventilated BIPV with heat recovery. Since the PV temperature is reduced compared to non-vented applications, the lifetime of the PV system is expected to be at least equal to conventionally accepted lifetimes for PV.

As a note, however, it is good to know that a number of demonstration projects have been suffering from vandalism. At the Mataro library, a substantial number of the PV modules in the facade show cracks, and also stickers have been pasted over the PV. In addition, Cartmell [197] also reports vandalised PV modules at the Brockshill Environment Centre.

\subsection{Conclusion BIPVT facades}

In BIPVT applications, flow velocities are generally low and buoyancy and wind have significant effects. A substantial variation in thermal module efficiencies is reported, due to the large effect of flow rate and channel design. However, for practical flow rates, the thermal efficiency for unglazed modules is rather low. Effective and low-cost methods to increase the heat transfer need to be investigated and implemented. The electrical performance is enhanced by about $10 \%$ as compared to non-ventilated PV. 
Table 2

Climatic parameters for various countries

\begin{tabular}{lllll}
\hline Country & Latitude & $\begin{array}{l}\text { Annual irradiance } \\
\text { horizontal } \\
{\left[\mathrm{kWh} / \mathrm{m}^{2}\right]}\end{array}$ & $\begin{array}{l}\text { Ratio horizontal irradiance } \\
\text { winter/summer }\end{array}$ & $\begin{array}{l}\text { Ratio irradiance } \\
\text { façade/roof } 35^{\circ}\end{array}$ \\
\hline Jerusalem & 31 & 2101 & 0.41 & 0.57 \\
Tokyo & 35 & 1276 & 0.54 & 0.66 \\
Athens & 38 & 1567 & 0.31 & 0.62 \\
Washington & 39 & 1487 & 0.34 & 0.65 \\
Ottawa & 45 & 1378 & 0.24 & 0.71 \\
Vienna & 48 & 1113 & 0.16 & 0.67 \\
London & 51 & 958 & 0.14 & 0.69 \\
Stockholm & 59 & 983 & 0.06 & 0.75 \\
\hline
\end{tabular}

Source: Meteonorm.

For the northern hemisphere, winter is defined as November-January, while summer is defined as May-July. For the Southern Hemisphere, this is reversed.

\section{PVT systems}

\subsection{Introduction}

For thermal collectors, the yield is not only determined by the quality of the collector, but at least as much by the climate and the type of system it is used in. For the effect of the system, important parameters are the required temperature level and the solar fraction to be realised. For the effect of the climate, important differences are the annual amount of irradiance and the variation of the irradiance over the year. In particular, cold but sunny winter days are good for solar space heating. In Table 2 these differences are illustrated. Due to the very high difference between summer and winter irradiance, the Northernmost climates require a large amount of storage to obtain a significant solar fraction for room heating, while regions such as the south of Canada, the USA or Japan can cover a much larger share of their heating load with direct solar heating (see also [9]). Also in the PVHYBRID-PAS report [245] the effect of climate on PVT façade performance is emphasised.

\subsection{PVT-liquid collectors}

- In the work of Kern and Russell [27,28] at MIT, an energy and economic comparison was made for a combination of a glazed PVT collector with several system configurations (direct solar heating with vapour compression air conditioning; parallel heat pump; series heat pump; absorption air chiller; series advanced heat pump) for 4 climatic regions in the USA. It was concluded that while the combination of PVT with the advanced heat pump provided the lowest auxiliary heating demand, for residences the direct solar heating system was much more economical because of its lower first cost. For offices, it was concluded that PV was more economical than PV-Thermal.

- At JPL, research was started in 1980 as part of the JPL Flat-plate solar array project [31]. Simultaneously, work was carried out at Brookhaven [30], commissioned by JPL. In the report of Andrews, it is concluded that PVT for medium temperature 
applications is not economically attractive due to the lower yield of the PV. Only for low-temperature applications such as the swimming pool collector would the PVT be marginally attractive, while the combination of unglazed PVT and a heat pump warranted further study. However, Andrews states that the outlook for PVT would be improved by PV cost reduction, which has certainly occurred from 1981 up till now. In the paper of Gasner and Wen, the combination of unglazed PVT with a heat pump for space conditioning, as compared to the same heat pump powered by the utility or by PV-only, was examined for 5 USA climatic regions. It was stressed that previous research had concentrated on glazed PVT, which had the additional problems of high stagnation temperature and relatively high cost, while for the unglazed design the low add-on cost was stressed to turn PV into PVT. However, it turned out that for all regions the BOS cost of the thermal system made the PVT system uneconomical. It was recommended to improve the economics by using PVT collectors in multi-family houses, rather than single-family residences, and by including hot tap water for residential applications.

- In 1989, Hayakashi et al. [88] presented a system in which a roof was covered by $48 \mathrm{~m}^{2}$ of PV-modules, which were connected to transparent tubes, which were filled with a black fluid. The electrical energy was stored in batteries and the thermal energy was stored into two water tanks of $1 \mathrm{~m}^{3}$ each. A heat pump and a gas heater were used for reheating the fluid. The system was used for generating hot water and floor heating. Monitoring over a year indicated $84 \%$ thermal coverage and 59\% electrical coverage of the energy-requirements of the house.

- Nishikawa et al. [92] describe a system in which the PVT functions directly as the evaporator of a heat pump. The collector liquid is the refrigerant R22. It was found that high COP's could be found, whereas the PV was efficiently cooled. Ito et al. [90] present analytical results on the sensitivity of the system to collector area, W/D and thickness of the collector plate. In a further research, Ito et al. [253] indicate that under low irradiance conditions, the COP of the heat pump is very low, due to the fact that a flatplate collector with an insulated rear is not optimised for extracting heat from the ambient air. The problem was solved by adding a $3.24 \mathrm{~m}^{2}$ multiple-fin evaporator in parallel with the $2.45 \mathrm{~m}^{2}$ PVT absorber, which raised the COP from about 2 to about 3 at low irradiance conditions, while at high irradiance a COP of 6 was found. Ito et al. [91] present analytical results on this dual source system.

- At the Indian Institute of Technology, research was carried out on a thermosyphon PVT water heater [98] and forced flow water heater [100]. They calculated that for a clear day with an ambient temperature of about $45^{\circ} \mathrm{C}$, for forced flow application at an optimum flow rate of $54 \mathrm{~kg} / \mathrm{m}^{2} / \mathrm{h}$, their $2 \mathrm{~m}^{2}$ collector could heat up water from $31^{\circ} \mathrm{C}$ up to $73{ }^{\circ} \mathrm{C}$ for a $100 \mathrm{~kg}$ storage (average daily thermal efficiency $38 \%$ ), versus about $57{ }^{\circ} \mathrm{C}$ for a $200 \mathrm{~kg}$ storage (average daily thermal efficiency $48 \%$ ). They emphasise that the pump will switch off earlier in the evening if a higher flow rate is used, due to the fixed temperature differential settings in the control unit, thereby reducing the thermal yield. For thermosyphon application, the temperature increase was roughly the same. The device would be suitable for rural areas, where the amount of electrical energy produced would be sufficient to run two light tubes and a television, in addition to driving the collector pump.

- De Vries [43] and Zondag et al. [45,46] made calculations for a $3.5 \mathrm{~m}^{2}$ PVT solar boiler with a storage tank of 1751 in the Dutch climate. Various PVT designs were examined 
(sheet-and-tube, channel, secondary channel), resulting in annual efficiencies in the range of $34-39 \%$ for the different covered PVT collector designs, and $24 \%$ for an uncovered sheet-and-tube collector (as opposed to $51 \%$ for a conventional thermal collector). Based on ease of module manufacturing, the covered sheet-and-tube system was found to be the most promising PVT concept for tap water heating.

- Zondag et al. [57] and Jong [271] made a comparison between various types of PVT designs (covered and uncovered) and various types of thermal systems (domestic hot water or heating with or without heat pump) in the Dutch climate. In this study, it is concluded that an uncovered PVT system only gives a good efficiency for the case in which the PVT is used for low-temperature ground storage combined with a heat pump, due to the increase in thermal efficiency and running hours for such low inflow temperatures, but that the net electrical efficiency of the system becomes negative in this case, due to the energy consumption by the heat pump.

- Elswijk et al. [54] carried out a study on the installation of large PVT collector arrays on multi-family buildings. He concluded that the use of PVT would save about $38 \%$ in area, relative to a side-by-side system of PV and solar thermal, which was important because of the limited roof space per household available. A point of attention was the fact that the shading angle for PVT collectors should be smaller than for conventional solar thermal collectors, because of the detrimental effect of PV-shading, resulting in a larger spacing between the collectors.

- Zondag et al. [60] presented monitoring results on the $54 \mathrm{~m}^{2}$ glazed PVT array installed at the head office of Renewable Energy Systems. The PVT heats an underground seasonal storage tank. The stored heat is used to provide space heating during the winter. The PVT array was found to have supplied about $34 \mathrm{MW} \mathrm{h}$ of thermal energy over the first year. The average module efficiency was found to be roughly $13 \%$ for the PVT collectors versus about $23 \%$ for the conventional solar thermal collectors installed.

- Bakker et al. [53] examine a system in which a heatpump with a ground heat exchanger extracts heat from the ground to provide hot water and space heating for a Dutch residence. In order to avoid a long-term decrease of the ground temperature, with the associated reduction of heat-pump efficiency, an unglazed PVT collector is used to restore the heat to the ground. It is concluded that this system is able to cover the electrical and thermal demand of the building fully while keeping the long-term ground temperature constant. In addition, total investment costs for the PVT system were found to be equal to the investment costs for a side-by-side PV and solar thermal system (dimensioned for the same yield), while the PVT system required $25 \%$ less area.

- Kalogirou and Tripanagnostopoulos [294] calculated the yield of a $4 \mathrm{~m}^{2}$ PVT thermosyphon system for different climates. For their crystalline silicon PVT module they found a useful thermal gain of $5.7 \mathrm{GJ}$ for Nicosia, $5.0 \mathrm{GJ}$ for Athens and $3.8 \mathrm{GJ}$ for Madison, while the electrical performance ranged from 532 to $499 \mathrm{~kW} \mathrm{~h}$. For the same module using a-Si, the thermal performance was slightly higher while the electrical performance was halved.

- Ji et al. [215] study a facade integrated $40 \mathrm{~m}^{2}$ PVT collector for use in residential buildings in Hong Kong, comparing thin film and crystalline silicon. For water heating, the annual thermal efficiencies were found to be $48 \%$ for the thin film case and $43 \%$ for the crystalline silicon case. It was concluded that the system could serve as a pre-heater for hot water. In addition, the system was found to reduce the cooling requirements of the building substantially due to the reduced absorption of heat by the walls. These 
combined effects lead to the conclusion that the hybrid PVT wall has significant application potential in a sub-tropical city like Hong Kong.

\subsection{PVT-air}

\subsubsection{Introduction}

Various possible types of solar air systems exist. An overview is given by Hastings and Mørck [254,255]. Here, the following systems are distinguished:

- heating of incoming ventilation air;

- circulating the room air through a solar collector;

- circulating heated air through a cavity in the building envelope or the floor (from where the heat can be brought to the rooms by passive or active means) and

- heating water through an air-to-liquid heat exchanger, after which the heated water can be used as tap water or for space heating.

For BIPV facades, one more application can be added:

- assisting the building ventilation by means of natural convection, through use of the PV facade as a natural chimney

\subsubsection{PVT air collectors}

For PVT air collector systems, several projects have been carried out

- Komp and Reeser [113] report on the design and installation of a $17 \times 2.5 \mathrm{~m}^{2}$ stationary concentrating glazed roof-integrated PV-air collector for an off-grid dwelling for 4 persons. The dwelling is situated in Kentucky and is actually an enclosure built around a house trailer. The collector is driven by natural convection and has fins to improve the heat transfer to the air. During the winter, the heated air is drawn into the house by a fan, while during the summer it is evacuated to the ambient by natural convection (quite similar to the PV-Hypri design shown in Fig. 12, which was discussed previously). The electrical yield is used, among others, for lighting, a satellite TV dish and the running of a plastic injection-moulding machine (as a cottage industry for income generation).

- In 1994 Cythelia designed the 'Capthel collector' using a-Si [115]. The system is glass covered and the air-section consists of square aluminium channels. Two prototypes are presented: the Capthel01 with an efficiency of $55 \%$ at a flowrate of $39 \mathrm{~m}^{3} / \mathrm{m}^{2} / \mathrm{h}$ and the Capthel02 with an improved heat transfer to the air, resulting in an efficiency of $63 \%$ at a flowrate of $45 \mathrm{~m}^{3} / \mathrm{m}^{2} / \mathrm{h}$. The module costs were estimated at $370 \$ / \mathrm{m}^{2}$, consisting of $250 \$ / \mathrm{m}^{2}$ for the PV and $120 \$ / \mathrm{m}^{2}$ for the thermal part, while $\$ 80 / \mathrm{m}^{2}$ worth of facade materials could be saved. The collector is presented as part of the Ecothel system concept, including water heating through a water-to-air heat exchanger and heat storage in a rock bin. An economic evaluation of the Ecothel system is presented for application in a private home and in a commercial building. In a later stage, an unglazed version of the Capthel collector was developed to reduce the PV temperature (Ricaud 2006, personal communication).

- Grammer Solar and Aidt Miljø have designed air collectors in which only a small part of the absorber area is covered by PV. The PV drives a direct current fan, resulting in a 
system that can autonomously provide preheated ventilation air. The main market consists of vacation cottages [14,17].

- Two unglazed PV-air hybrid collectors by Grammer KG have been installed in the OKA Haus der Zukunft in Austria, together with 18 conventional air collectors. The heat generated by the collectors is use for tap water heating and floor heating, combined with a $100 \mathrm{~m}^{3}$ concrete hypocaust [255]. Other projects in which the hybrid collector of Grammer was applied, are a painting facility in Nürnberg $\left(1996 ; 47 \mathrm{~m}^{2}\right)$, the Nürnberg Zoo $\left(1999 ; 75 \mathrm{~m}^{2}\right)$, the office of the city cleansing department in Leipzig $\left(2000 ; 120 \mathrm{~m}^{2}\right)$, the Millennium Park in Oadby, UK $\left(2000 ; 34 \mathrm{~m}^{2}\right)$, a visitors centre in a national park in Germany $\left(2001 ; 23 \mathrm{~m}^{2}\right.$ ), a swimming pool in Pliezhausen $\left(2001 ; 86 \mathrm{~m}^{2}\right)$ and the Atrium of the University of Pirmasens $\left(2002 ; 14 \mathrm{~m}^{2}\right)$. In almost all cases, the systems are used for preheating of ventilation air, but in two cases (the visitors centre and the city cleansing department), also water is heated [35].

- Conserval Engineering has carried out a number of installations of its PV-Solarwall concept, among which a $15 \mathrm{~m}^{2} \mathrm{PV}$-Solarwall at a portable classroom at the West Preparatory School in Toronto in 1998. The PV (two modules of $60 \mathrm{Wp}$ ) power the fans that bring the solar heated ventilation air into the classroom, whereby the system displaces electrical heating. The system cost was $\$ 5000$. Other systems are a $46 \mathrm{~m}^{2}$ system at the Chewonki foundation and a $26 \mathrm{~m}^{2}$ system at the Korean Institute for Energy Research ([35], www.solarwall.com, leaflet www.cansia.ca).

\subsubsection{BIPV with heat recovery}

5.3.3.1. Introduction. Although in principle the systems for BIPV air are the same as for PVT-air collectors, in practice a number of differences exist, due to the fact that the systems are unglazed and the volume flow is generally much lower, such that even natural convection is applied. Therefore, such systems seem generally less appropriate for tap water heating and circulating the air through the building envelope, but can be suitable for preheating of ventilation air, circulating room air through the air collector or assisting the ventilation due to the draft generated by natural convection.

Both façade-integrated and roof-integrated PVT systems have been investigated. Whereas roof systems have the benefit of higher insolation, facade systems have the benefit of replacing expensive facade cladding materials.

\subsubsection{Façade-integrated systems}

- Atlantis Energy Ltd. built a PVT-air facade at the Scheidegger building [131]. An $18 \mathrm{~kW}_{\mathrm{el}}$ facade of PV-elements was built in front of a wall. The PV elements were slightly tilted upwards in order to increase the PV-efficiency. The lower rim of each PVmodule is connected to the upper rim of the module below it by a downward tilted mirror-element, which reflects some of the incoming light to the lower PV-laminate and at the same time encloses the heated air. Only a part of the wall is used to generate heat, since the windows should not be blocked. At the location of the windows, the PVlaminates are used for shading and the mirror-elements are not present in order to allow fresh air to come in. The thermal part produces $12 \mathrm{~kW}$ of heated air for the heating of the building, which is less than the electrical yield.

- As part of the PV-Vent project, ventilated PV facades were installed at two multi-family buildings. Within this project, different prototype-ventilated PV systems were tested 
with typically $1 \mathrm{~m}^{2}$ of ventilated PV per apartment, together with a heat recovery ventilation system. At the Lundebjerg building, PV-Vent prototypes were applied in a retrofit project of 513 apartments, featuring $60 \mathrm{~m}^{2}$ ventilated a-Si modules at the Southern facade, $21 \mathrm{~m}^{2}$ of c-Si PV ventilation chimneys and $3 \mathrm{~m}^{2}$ ventilated c-Si modules at the Western facade [138]. At the Sundevedsgade PV was integrated in the cover of a solar wall. Pedersen [138] indicates that the simple payback time of PV can be reduced from 44 to 17 years by also using the heat from the PV. It was found, however, that the actual benefit of pre-heating of fresh air was low, due to the low thermal efficiency of the unglazed PV-facades, the high efficiency of the heat recovery in the ventilation system and the fact that wide air gaps were required to allow natural ventilation to cool the PV during the summer. In addition, it was found that the PV temperature was often over $50{ }^{\circ} \mathrm{C}$, which implied that the PV cooling was not effective. It was recommended to evaluate the application of ventilated PV carefully before application in future projects $[139,140]$.

- The ELSA building on the Joint Research Centre site in Ispra (Italy) has been retrofitted with $770 \mathrm{~m}^{2}$ of a-Si modules, covering a well-insulated wall. The air gap between the PV façade and the wall is sectioned into 30 solar chimneys of $12 \mathrm{~m}$ high, $1.6 \mathrm{~m}$ width and $0.23 \mathrm{~m}$ depth. The hot air could serve for heating during the winter and deliver the driving force for ventilation cooling during the summer [149]. However, it was later decided that the adaptation of the heating system, in order to allow it to use this heat, was not feasible (Bloem, personal communication).

- At the public library in Mataro (Spain), a system of $603 \mathrm{~m}^{2}$ ventilated PV was realised, consisting of a ventilated PV façade and ventilated PV shed roofs. The facade is $37.5 \mathrm{~m}$ wide and $6 \mathrm{~m}$ high $\left(225 \mathrm{~m}^{2}\right)$ and consists of 108 semitransparent c-Si modules $(20 \mathrm{kWp})$. The width of the channel behind the PV facade is $15 \mathrm{~cm}$ and the rear boundary is provided by a glass wall. The façade is $15 \%$ transparent for purposes of building illumination. The 4 shed roofs $\left(37^{\circ}\right.$ tilt) have a combined area of $378 \mathrm{~m}^{2}$ and use different types of PV (450 opaque mono c-Si modules, 150 opaque poly c-Si modules and 96 semitransparent a-Si modules). During winter operation, the solar heated air is used as preheated air in the conventional gas heating system. During the summer, the air is evacuated to the ambient $[181,182,276]$. In a subsequent project, an area of $61 \mathrm{~m}^{2}$ of specially adapted conventional air collectors was added in order to be able to provide hot air for direct space heating [244]. Systems studies were carried out for the PVT facade in various climates (Barcelona/Mataro, Loughborough and Stuttgart). It was found that in all three climates, in comparison with a brick wall, the PVT facade increased the cooling load, but only in Barcelona the heating load was reduced significantly by means of the facade. Finally, it was decided to use the hot air during the summer for a desiccant cooling system that was installed as part of a third EU project. Eicker et al. [185] present a study on the heating and cooling potential of PVT facades, indicating net thermal gains during the winter of $68 \mathrm{~kW} \mathrm{~h} / \mathrm{m}^{2}$ for Barcelona $\left(63 \mathrm{~kW} \mathrm{~h} / \mathrm{m}^{2}\right.$ solar gain, $19 \mathrm{~kW} \mathrm{~h} / \mathrm{m}^{2}$ transmission loss recovery and $31 \mathrm{~kW} \mathrm{~h} / \mathrm{m}^{2}$ direct gain through the semitransparent PVT, from which $45 \mathrm{~kW} \mathrm{~h} / \mathrm{m}^{2}$ remaining transmission losses should be subtracted) as compared to $53 \mathrm{kWh} / \mathrm{m}^{2}$ in a Southern German climate. For the summer, the ventilated PV facade would be able to supply $62 \mathrm{~kW} \mathrm{~h} / \mathrm{m}^{2}$ and the PVT shed roofs $128 \mathrm{kWh} / \mathrm{m}^{2}$ for solar cooling. It was indicated that the Mataro $225 \mathrm{~m}^{2} \mathrm{PVT}$ facade would be able to supply $20 \%$ of the required heat for solar cooling, while the existing $300 \mathrm{~m}^{2} \mathrm{PV}$-shed roofs could supply another $37 \%$. The remaining $43 \%$ could be 
provided by an additional solar air collector field of $100 \mathrm{~m}^{2}$. In the final report on the PVT cooling project at Mataro, Eicker [192] presents simulations showing an average COP of 0.52 and an average solar fraction of 0.93 over the summer season for the desiccant cooling system. In addition, the solar system was found to be able to supply one third of the heating demand during the winter season.

- A large amount of work on systems studies was carried out in the project PV-HYBRIDPAS. As part of this project, a study was carried out by Wouters et al. [164], in which simulations were carried out for various types of buildings in various European climates (Denmark, Belgium, Italy). It was concluded that the key challenge of PVT was to find nearby applications which have a sufficient heating demand: large office buildings might not be suitable for PVT because of the relatively low heating demand, whereas swimming pools, both covered and open air, as well as buildings with a low level of insulation and a relatively small glazing area could provide interesting applications. Furthermore, a large part of the work in the PV-HYBRID-PAS project involved the analysis of a number of case studies [245], being the Brundtland Centre, the ELSA building, College la Vanoise, a Lighthouse, Thessaloniki Hospital, Linford house and a Swimming pool. All these buildings were simulated with a BIPVT facade or roof with various applications for the heat, such as preheating ventilation air (either for direct use or with short term storage in the building mass), the use of the stack effect to provide natural ventilation cooling, preheating tap water through a heat exchanger, or pool heating. A number of conclusions was drawn:

$\bigcirc$ The application of hybrid PV is not necessary very efficient and great care is needed when considering an application. An optimal integration with the HVAC design and an evaluation of the hybrid PV for each specific case is essential.

$\bigcirc$ BIPVT works best when ventilation is a major component of the building heating loads.

O Direct use is preferred, but short-term storage can be effective, especially in transitional seasons where the PV heat is significant and there is a need for heating only in the morning or afternoon.

The performance of ventilated PV is very sensitive to climate. The best results are obtained in a climate with cold but sunny winter days. From Table 2, it can be seen that this excludes most of Northern Europe.

$O$ Using buoyancy induced by a high BIPVT facade for ventilation cooling during the summer months may provide air change rates are in the order of 1-4 air changes per hour, which is significant but does not eliminate the need for additional cooling in Southern Europe. In addition, controls are required.

$O$ Using BIPVT to heat tap water generally seems ineffective because the resulting raise in temperature of the water is small and the system is therefore probably not economical.

Swimming pools seem to be a very interesting application, since all heat can be used and matching problems do not exist.

The cooling effect on the PV is only relevant for the c-Si laminates. For facade or roof integration of a-Si, the effect is small.

- For a $260 \mathrm{~m}^{2}$ facade for a hotel in Macau, Chow [252] compared the options of BIPV, PVT and ventilated PV (without heat recovery). The airflow for the PVT was driven by natural convection, whereas for the ventilated PV both natural convection and wind effects were assumed to drive the ventilation of the PV. He found that, although the 
electrical performance for the three options was similar, the PVT and ventilated PV options were to be preferred to the BIPV option because of their reduction in the cooling demand of the building. The PVT option was found to provide $68 \mathrm{GJ}$ of thermal energy during the summer that could be used for water pre-heating. For the remainder of the year, the temperature raise in the PVT facade was less than $5^{\circ} \mathrm{C}$, which Chow concludes to be too low for practical use.

- Kondratenko [201] did calculations on the facade of the Graham Hills Building, belonging to the University of Strathclyde. A semi-transparent double skin facade was examined with and without PV. It was concluded that for this application, the thermal contribution of the PV was insignificant, as the contribution to the preheating of the ventilation air by the cells went at the expense of the direct gains to the building. This is similar to the findings in the Mataro project, where it was indicated that a glazed facade without PV would have higher net thermal gains than a ventilated semitransparent PV façade. However, it was also indicated that these direct gains would be much more complicated and costly to control [244].

- For both a single-family house and a multifamily building, Guiavarch and Peuportier [209] calculated the thermal yield of a BIPVT system for the climates of Paris and Nice. They compared an opaque c-Si PV system and a semitransparent c-Si PV system with a secondary absorber at the channel rear. The thermal yield was used for the preheating of ventilation air for either the North or the South side of the building. In the case of a single-family house in Paris, for the semitransparent modules, the thermal yield was typically in the same order as the electrical yield, while for the opaque modules the thermal yield was substantially lower. In the case of Nice, as compared to Paris, the electrical output went up while the useful thermal output went down, which was due to the reduction in thermal demand.

- At the Fiat Research Centre (CRF), a ventilated c-Si PV facade was installed as part of the ECO-canteen. The PV is ventilated by means of a forced variable airflow up to $9000 \mathrm{~m}^{3} / \mathrm{h}$. During the winter, the heat generated by the ventilated PV facade is used for heating purposes. During the summer, the heat is used for a solar cooling system. Adhikari et al. [204] found that the $160 \mathrm{~m}^{2}$ ventilated PV façade could provide about $28 \%$ of the heat required in the cooling system, while the remainder was provided by a cogeneration plant. Butera et al. [205] indicate that a further $32 \mathrm{~m}^{2}$ of conventional solar thermal air collectors was added to boost the performance of the ventilated facade. Over the year, the hybrid facade was estimated to produce $20 \mathrm{MWh}$ of electricity and $100 \mathrm{MW}$ h of thermal energy.

\subsubsection{Roof-integrated systems}

- Loferski et al. [112] report on a building on the campus of the Brown University, of which the energy requirements for space heating and domestic hot water are met by a system of 20 PVT-air collectors of $1.8 \mathrm{~m}^{2}$ each in which a fin has been added to the back of each PV-cell (which is claimed to double its thermal output). The thermal system consists of the PVT-module, a heat pump and a rock bin thermal storage unit. Simulations indicated that $65 \%$ of the total energy needs of the building (electrical + thermal) could be met by the system.

- Posnansky and Eckmanns [134], from Atlantis Energy Ltd., report on a PVT-air system on the building of the factory 'Aerni Fenster' in Arisdorf (Switzerland). A hybrid 
$53 \mathrm{~kW}_{\mathrm{el}}$ system is integrated into the skylights. Through the backside cooling of the PV elements with air, $115 \mathrm{~kW}$ of additional thermal power is obtained. During the heating season, the hot air is used for direct heating of the building or temporarily stored in the concrete foundation of the building. During the summer, the thermal energy is stored in an underground storage and retrieved in the winter with a heat pump. Thermal efficiencies were reported in the range of 32-45\%. Posnansky and Eckmanns [134] also present measurements on two PVT-air shingle roofs 'Brig'and 'Rigi', installed in 1993. The tiles are cooled by natural convection, and in the winter this hot air is drawn into the building by a fan. For the system 'Brig', this hot air is used for the direct heating of the shower rooms. The installed power is given as $15 \mathrm{~kW}_{\mathrm{el}}$ and $30 \mathrm{~kW}_{\text {th }}$ for 'Brig', while the system 'Rigi' has an installed power of $8.4 \mathrm{~kW}_{\mathrm{el}}$ and $12 \mathrm{~kW}_{\mathrm{th}}$. Finally, in Posnansky et al. [132], the PVT-air project 'Erlach' is presented, in which PVT air collectors are installed on a school, preheating water for the showers in the gym and the caretakers home through an air-to-water heat exchanger. The system is built in 1996 and produces $14.5 \mathrm{~kW}_{\mathrm{el}}$ and $29 \mathrm{~kW}_{\mathrm{th}}$. It is stated that cogeneration of hot water with buildingintegrated $\mathrm{PV}$ is recommendable with sizes above $15 \mathrm{~kW}_{\mathrm{el}}$, whereas for smaller systems the generated air should be used directly (e.g. heating, ventilation) or a supplemental thermal collector might be preferable.

- Kropf [136] did a PhD study on PVT-slates ("PVT-schiefer") as produced by Atlantis energy [135]. Within this study, he did prototype measurements on PVT slates, developed a simulation model for dynamical calculation of the heat gain and produced a yield atlas for three locations in Switzerland (Zurich, Lugano and Davos), in which he subdivided the monthly thermal output into the available temperature levels. $\mathrm{He}$ indicated that low-temperature demand is essential for the efficient use of BIPVT. As most promising applications, he found hot water preheating for a hotel in Lugano $\left(50 \mathrm{~m}^{2}\right.$, efficiency $\left.22 \%\right)$ and seasonal ground heat storage for a low-energy house in Davos.

- Sheinkopf describes a $1.6 \mathrm{kWp}$ PVT-air system that is installed on the roof of an Applebee restaurant in the USA. The system consists of $32 \mathrm{a}-\mathrm{Si} \mathrm{PV}$-modules and is used to generate hot water through a heat exchanger (see e.g. [14,194]).

- Fitzpatrick [194] reports on the $25 \mathrm{~m}^{2}$ BIPVT system on the drive-through canopy of the Central Carolina Bank. The heat generated by the ventilated PV is used for preheating of ventilation air from October to April, while during the summer it is vented to the ambient. The ventilation of the PV is driven by a fan directly powered by the PV, which therefore is in operation only when heat can be harvested. The thermal gain was found to be $3400 \mathrm{kWh}$ together with an electrical output of $2500 \mathrm{kWh}$. It was concluded that the benefit of harvesting thermal energy for ventilation air was small in the North Carolina climate.

- Zondag and Van Helden [58] carried out a numerical study on $30 \mathrm{~m}^{2}$ roof-sized PVT air collectors for domestic water heating through an air-to-liquid heat exchanger in the Dutch climate. It was found that glazing of the collector area increased the thermal yield by about $50 \%$, while the use of a closed loop system instead of an open loop system doubled the yield, assuming that no air leakage would occur in the closed-loop system. For such a large PVT area, it was found that for an open-loop unglazed air collector a solar fraction of $18 \%$ of the tap water demand could be realised, while for a closed-loop glazed PVT air system a solar fraction of $56 \%$ could be generated even with a nonoptimal design (low flow rate, large square channels). 
- After their work on the Mataro library, the Spanish company TFM developed the $1000 \mathrm{~m}^{2}$ ventilated semi-transparent PV roof at the Imagina studios in Barcelona. Whereas part of the produced heat is simply ventilated to the ambient, part of it is used for the heating of the canteen. However, no monitoring is carried out [256].

\subsection{Conclusions}

For PVT-liquid application, glazed PVT systems for domestic water heating are a promising application, but also utility buildings with a high tap water demand should be considered. In addition, the combination of unglazed PVT with a heat pump is considered as very interesting, but the electrical consumption of the heat pump is substantial and should be taken into account in the system evaluation. It is clearly shown that the required area for a PVT system is less than for a corresponding side-by-side system, which it especially interesting for applications where available area is small, such as multi-family buildings, but also utility buildings with a large tap water demand such as hotels and hospitals should be considered.

For PVT air and BIPVT applications, preheating of ventilation air seems a very logical application, especially for buildings with a large ventilation demand. However, since this is required only during the heating season, it is worthwhile to look for summer application of the heat as well. For domestic application, as well as for utility applications with a large tap water demand, the heat may be used for the heating of water through a heat exchanger. For utility buildings, the heat may be used for solar cooling, or the buoyancy effect may be used to assist the ventilation. For unglazed BIPVT applications, the thermal efficiency will be low and care should be taken to optimise the integration of the BIPVT into the HVAC system as a whole, which requires good design tools. The optimisation of the system will strongly depend on climate.

\section{PVT and the market}

\subsection{Introduction}

Presently, the work on PVT is rather scattered, and only a very limited number of systems has been built. The only products that have a modest market share at present are air-type collectors for autonomous applications. Ventilated PV systems have mostly been built as specific solutions for individual projects (although recently Secco Sistemi has developed a standardised system), while PVT concentrators as well as glazed and unglazed PVT-liquid collectors are commercially available but not yet produced in significant quantities. A number of PVT market inventories has been made over the years $[9,10,13,14,17]$. However, the number of market potential studies is small $[9,17,220]$. In addition, an investigation of the potential of PVT in industry was presented by Battisti and Tripanagnostopoulos [257]. In following paragraphs, an inventory on the market potential of PVT liquid and PVT air is made.

\subsection{Glazed PVT liquid collectors}

The largest market potential is seen for liquid-type PVT for domestic hot water, possibly combined with space heating. At present, about $90 \%$ of the European conventional solar 
collector market is residential, consisting of $80 \%$ domestic hot water systems and $10 \%$ space heating systems, which are normally combi systems [258]. Although most collectors are installed on single-family houses, the share of large systems for collective applications is expected to increase. In the PVT roadmap [17], water heating systems for the residential market are indicated as the main market for glazed PVT systems, while public pool systems and large hot water systems (both for collective applications and for utility application such as hospitals, campgrounds and homes for the elderly) are presented as interesting niche markets.

At present, for the glazed PVT collectors required for this application, there is potential for further improvements with respect to the issues associated with high stagnation temperature, as well as the relatively large collector losses, both due to reflection and thermal losses. In addition, non-technical issues such as certification and building integration, such as the development of plug-and-play installation, are at least as important as the technical ones, and should receive more attention.

\subsection{Unglazed PVT collectors}

The market for conventional unglazed liquid collectors consists primarily of pool heating applications. The potential of unglazed pool heating collectors in Europe is small; after the modest peak in the early 1990s, the market has declined in European countries such as the Netherlands, Austria, and France, while in Germany and Sweden the amount of newly installed unglazed collectors has been more or less constant over the last decade [258]. However, in the USA or Australia, where the pool collector market is much larger [259], a larger potential exists. Finally, a large new market for unglazed PVT collectors is opened if these collectors can be combined successfully with a heat pump. In that case, the domestic market may present a large future potential.

\subsection{PVT air collectors}

The commercially available PVT modules are mainly air type with unglazed PV. This is mostly due to the fact that in this application, the PV is effectively cooled; thereby increasing the electrical yield, and conventional PV modules can be applied, thereby making use of the large volume of the existing PV market and associated lower costs. A problem is the limited application of air heating systems in the domestic market, as indicated by the fact that air collectors have a market share of less than $1 \%$ of the worldwide solar collector market [259]. However, the market for air heating systems might well grow in the future, due to the reduction in domestic heating demand and the increasing application of ventilation systems with heat recovery, allowing for easy integration of air collectors. In particular, passive houses, of which the entire heating demand can in principle be met by heated ventilation air (www.passivehouse.com), are gaining attention and may be a standard for the future. Also the utility market is very interesting for air collectors, due to the requirements for air conditioning and often high required ventilation rates (e.g. schools), as well as a better match between solar supply and heating demand.

\subsection{Ventilated $P V$ facades with heat recovery}

The market for PV facades is expected to show a substantial growth in the future, due to increasing experience with PV facade integration and due to decreasing PV prices, and the 
market for ventilated PV facades with heat recovery is expected to follow. The potential of this application is mainly seen in utility buildings. A strong point for this market is the fact that the heating demand and the irradiance both peak during working hours, allowing for a substantial amount of direct heating. A problem might be that, in buildings with a large share of direct solar gain, the heat from the PV facade is in competition with the heat generated by passive means. Also, the temperature level that can be provided will be low, due to the low thermal efficiency of PV facades, limiting the thermal contribution of this system, which demands a carefully optimised design. As concluded in the PV-HYBRIDPAS project [245], an optimal integration with the HVAC design and an evaluation of the hybrid PV for each specific case is essential. A challenge is to use also the heat that is generated during the summer; this may be done by using the stack effect to boost the ventilation, or by preheating air for solar cooling.

\subsection{Conclusions}

A number of conclusions can be drawn on the module level. In can be concluded from the considerations above that a large research agenda exists for the future.

\section{PVT liquid:}

- For glazed PVT liquid modules, stagnation issues have to be solved. Several possibilities exist for solving these, such as an alternative encapsulation method (e.g. silicones) or the application of an active overheating protection.

- The thermal efficiency has to be improved. This requires both an improvement in the absorption of the PVT and a reduction of the thermal losses by means of spectral selectivity or improved insulation, e.g. by means of double covers of highly transparent glass.

- More experience should be obtained for unglazed PVT collectors combined with a heat pump, since this may be a promising development for the future.

\section{PVT air:}

- For glazed PVT air modules, the same holds as for glazed PVT liquid modules in terms of stagnation temperature resistance of the encapsulant, as well as thermal efficiency. Unglazed PVT air modules, which do not suffer from high stagnation temperatures, have as an advantage the ability to use conventional PV laminates, profiting from the large-scale production of conventional PV modules. This advantage would disappear if special PVT modules were used (e.g. because of higher thermal efficiency). This will limit the amount of techniques that can be used to optimise their thermal performance.

- For unglazed PVT-air collectors, optimisation of the heat transfer to the airflow is of primary importance.

- The development of standardised solutions for the integration of PVT air modules, possibly in combination with booster air collectors, in commercial air heating systems, is very important. 


\section{Ventilated PV facades with heat recovery:}

- Systems design should be optimised to make the best use of the limited thermal gain provided by ventilated PV.

- More insight is required in the savings that can be obtained by using the chimney effect of the facade to assist the building ventilation during the summer season.

- More research is required into techniques to boost the low heat transfer from the PV to the airflow. These techniques should be low cost and easy to apply, and allow the use of conventional PV modules.

With respect to systems level, the most important conclusion is that a serious lack in experience exists regarding systems performance, life time and reliability of PVT systems, due to lack of field tests and long term monitoring. It is very important that such projects are carried out, to generate experience, necessary for the development of standards for reliability and performance measurement, as well as for the generation of public confidence.

Finally, it should be stressed that not only technical issues are important, but that also general issues (certification, financing, subsidy structures, awareness and training) as well as integration issues (plug-and-play installation, design tools, aesthetics and standardised systems combining PVT with PV or solar thermal collectors) are essential for the market growth of PVT. A large part of this work has to be carried out by manufacturers, installers and policy makers. In addition, the building sector has an important role to play with respect to the large-scale market integration of PVT, particularly in new buildings and large renovation schemes. It is essential to obtain the involvement of these parties in order to make PVT a success. An overview of the various development issues and the drivers and barriers for the various parties in the market is presented in the PVT roadmap [17], that was generated as part of the EU project PV-Catapult (www.pvtforum.org). Further work will be carried out within the currently ongoing IEA SHC task 35 on PV/Thermal systems (www.pv-t.org).

\section{References}

[1] Coventry JS. Performance of a concentrating photovoltaic/thermal collector. Sol Energy 2005;78:211-22.

[2] Helgesson A, Krohn P, Karlsson B. Development of a MaReCo-hybrid for Hammarby Sjöstad 2004. In: ISES Eurosun, Freiburg, Stockholm, 2004.

[3] Rosell JI, Vallverdu X, Lechon MA, Ibanez M. Design and simulation of a low concentrating photovoltaic/ thermal system. Energy Convers Manage 2005;46:3034 46.

[4] Frankl P, Gamberale M, Battisti R. Life cycle assesment of a PV cogenerative system: comparison with a solar thernal collector and a PV system. In: 16th EPSEC, Glasgow, 2000.

[5] Tripanagnostopoulos Y, Tselepis S, Souliotis M, Tonui JK. Design aspects of hybrid PVT/water solar systems. In: 19th EPSEC, Paris, 2004.

[6] Tripanagnostopoulos Y, Souliotis M, Battisti R, Corrado A. Energy cost and LCA results of PV and hybrid PV/T solar systems. PIP 2005;13:235-50.

[7] Crawford RH, Treloar GJ, Fuller RJ, Bazilian M. Life-cycle energy analysis of builfing integrated photovoltaic systems (BiPVs) with heat recovery unit. Renew Sustain Energy Rev 2006;10:559-75.

[8] Coventry JS, Lovegrove K. Development of an approach to compare the 'value' of electrical and thermal output from a domestic PV/thermal system. Sol Energy 2003;75:63-72.

[9] Leenders F, Schaap AB, Jansen W, van der Ree BCG, Zondag HA, van Helden WGJ, et al. Technologieverkenning hybride PV/T concepten. November report 149.600-708.1, 1999.

[10] Soerensen H, Munro D. Hybrid PV/Thermal collectors. In: Second WSEBC, Sydney, 2000. 
[11] Meyer S. Wirkung eines hybriden Doppelfassadensystems auf die Energiebilanz und das Raumklima der dahinterliegenden Raume. PhD report, University of Cottbus, 2001.

[12] Bazilian MD, Prasad D, Erling P, Leenders F. Experimental testing of a modular photovoltaic cogeneration heat recovery system. In: PLEA 2001, Florianopolis, 2001.

[13] Photovoltaics/thermal Solar Energy systems - status of the technology and roadmap for future development. Report IEA PVPS T7-10, 2002.

[14] Bosanac M, Soerensen B, Katic I, Soerensen H, Nielsen B, Badran J. Photovoltaic/thermal solar collectors and their potential in Denmark. Report EFP Project 1713/00-0014, 2003.

[15] Charalambous PG, Kalogirou SA, Maidment G, Karayiannis TG. Photovoltaic thermal (PV/T) collectors: a review. Cyprus: HPC; 2004.

[16] Charalambous PG, Maidment G, Kalogirou SA, Yiakoumetti K. Photovoltaic thermal (PV/T) collectors: a review. Appl Thermal Eng 2007;27:275-86.

[17] PVT Roadmap - a European guide for the development and market introduction of PV-Thermal technology. Zondag, HA, Bakker M, Helden WGJ, editors. Report EU-Project PV-Catapult〈www. pvtforum.org $>, 2005$.

[18] Hendrie SD. Photovoltaic/thermal collector development program - final report. Report, MIT, 1982.

[19] Wolf M. Performance analysies of combined heating and photovoltaic power systems for residences. Energy Convers 1976;16:79-90.

[20] Evans DL, Facinelli WA, Otterbein RT. Combined photovoltaic/thermal system studies. Report ASU ERC-T-78017, 1978.

[21] Florschuetz LW. Extension of the Hottel-Whillier model to the analysis of combined photovoltaic/thermal flat plate collectors. In: Sharing the Sun joint conference, ISES, Winnipeg, 1976.

[22] Florschuetz LW. Extension of the Hottel-Whillier model to the analysis of combined photovoltaic/thermal flat plate collectors. Sol Energy 1979;22:361-6.

[23] Cox CH, Raghuraman P. Design considerations for flat-plate photovoltaic/thermal collectors. Sol Energy 1985;35(3):227-41.

[24] Hendrie SD, Raghuraman P. A comparison of theory and experiment for photovoltaic/thermal collector performance. In: 14th IEEE, San Diego, 1980.

[25] Hendrie SD, Raghuraman P, Cox CH. Liquid photovolaic/thermal collectors for residential applications. In: 15th IEEE, Orlando, 1981.

[26] Younger PR, Kreisman WS, Nowlan MJ, Solomon JS, Strong SJ. Combination photovolaic/thermal solar collectors for residential applications. In: 15th IEEE, Orlando, 1981.

[27] Kern EC, Russell MC. Combined photovoltaic and thermal hybrid collector systems. In: 13th IEEE, Washington, 1978.

[28] Kern EC, Russell MC. Hybrid photovoltaic/thermal solar energy systems. Report, MIT, 1978.

[29] Sheldon DB, Russell MC. A review of combined photovoltaic/thermal collector - solar-assisted heat pump system options. In: Fifth annual heat pump technology conference, Stillwater, 1980.

[30] Andrews JW. Evaluation of flat-plate photovoltaic/thermal hybrid systems for solar energy utilization. Report, Brookhaven, 1981.

[31] Gasner S, Wen L. Evaluation of unglazed flat-plate photovoltaic-thermal collectors in residential heatpump applications. In: ASME conference, Albuquerque, 1982.

[32] Suzuki A, Kitamura S. Combined photovoltaic and thermal hybrid collector. Japan J Phys 1979;19(2): $79-83$.

[33] Karl H. Photovoltaischer Hybridkollektor. In: Fourth international congress laser, 79 opto-electronics, Munchen, 1979.

[34] Komp RJ. Field experience and performance evaluation of a novel photovoltaic-thermal hybrid solar energy collector. Intersol 1985;85.

[35] PVT-platform. 〈www.ecn.nl/egon/extra/extranet/pvt-platform/het-pvt-platform >.

[36] Schwartz R, Rao KHS, Tscharner R. Computer-aided analysis of thermal images of solar cells and solar PV/T collectors. In: Fifth EPSEC, Athens, 1983.

[37] Tscharner R, Curthins H, Haring JP, Schwartz R, Shah AV. Low-temperature liquid PV/T collector. In: Fifth EPSEC, Athens, 1983.

[38] Lalovic B, Kiss Z, Weakliem H. A hybrid amorphous silicon photovoltaic and thermal solar collector. Sol Cells 1986;19:131-8.

[39] Lalovic B, Pavlovic T, Kiss Z, van Dine J. The application of hybrid a-Si:H PV and thermal collectors for different usages. In: Eighth EPSEC, 1988. 
[40] Van der Ree, BCG. Haalbaarheid van gecombineerde toepassing van fotovoltaische en thermische zonneenergie. Report TNO 93-BBI-R1198, 1994.

[41] Van der Ree, BCG. Tests aan prototype onafgedekte PV/Thermische collector. Report TNO 95-BBI-R1666, 1996.

[42] De Vries DW, Van Helden WGJ, Smulders PT, Van Steenhoven AA, Van Zolingen RJC. Design of a photovoltaic/thermal combi panel momentary output model, outdoor experiment. In: ISES Solar World Congress, Korea, 1997.

[43] De Vries DW. Design of a photovoltaic/thermal combi-panel. PhD report, EUT, 1998.

[44] Zondag HA, De Vries DW, Van Steenhoven AA, Van Helden WGJ, Van Zolingen RJC. Thermal and electrical yield of a combi-panel. In: ISES Solar World Congress, Jerusalem, 1999.

[45] Zondag HA, De Vries DW, Van Helden WGJ, Van Zolingen RJC, Van Steenhoven AA. The thermal and electrical yield of a PV-Thermal collector. Sol Energy 2002;72(2):113-28.

[46] Zondag HA, De Vries DW, Van Helden WGJ, Van Zolingen RJC, Van Steenhoven AA. The yield of different combined PV-thermal collector designs. Sol Energy 2003;74:253-69.

[47] Leenders F, Schaap AB, Ree BCG, van der Helden, WGJ van. Technology review on PV/Thermal concepts. In: 16th EPSEC, Glasgow, 2000.

[48] Bakker M, Zondag HA, Van Helden WGJ. Design of a dual flow photovoltaic/thermal combi panel. In: PV in Europe, Rome, 2002.

[49] Bakker M, Zondag HA, Elswijk MJ, Ottenbros MTN, Van Helden WGJ. Outdoor performance of uncovered PV/Thermal panels. In: 19th EPSEC, Paris, 2004.

[50] Zondag HA. Combined PV-air collector as heat pump air preheater. Staffelstein, 2001.

[51] Zondag HA, Van Helden WGJ. Stagnation temperature in PVT collectors. In: PV in Europe, Rome, 2002.

[52] Zondag HA, Van Helden WGJ, Elswijk MJ, Bakker M. PV-Thermal collector development-an overview of the lessons learned. In: 19th EPSEC, 2004, Paris, 2004.

[53] Bakker M, Zondag HA, Elswijk MJ, Strootman KJ, Jong MJM. Performance and costs of a roof-sized PV/ thermal array combined with a ground coupled heat pump. Sol Energy 2005;78:331-9.

[54] Elswijk MJ, Jong MJM, Braakman JNC, Lange ETN de, Smit WF. Photovoltaic/Thermal collectors in large solar thermal systems. In: 19th EPSEC 2004, Paris, 2004.

[55] Van Helden WGJ, Zondag HA. Photovoltaic thermal panels: on the brink of demonstration. In: PV in Europe, Rome, 2002.

[56] Van Helden WGJ, Zondag HA, Bakker M, Elswijk MJ, Jong MJM, Strootman KJ. PVT panels and PVT collectors: pathways to distributed solar cogeneration. In: ESTEC 2003, Freiburg, 2003.

[57] Zondag HA, Jong MJM, Van Helden WGJ. Development and applications for PV thermal. In: 17th EPSEC 2001, Munich, 2001.

[58] Zondag HA, Van Helden WGJ. PV-Thermal domestic systems. In: Third WCPEC, Osaka, 2003.

[59] Zondag HA, Bakker M, Van Helden WGJ, Affolter P, Eisenmann W, Fechner H, et al. PVT Roadmap: a European guide for the development and market introduction of PVT technology. In: 20th EPSEC 2005, Barcelona, 2005.

[60] Zondag HA, Bristow N, Gramsbergen E, Van Helden WGJ, Lloyd-Jones D, Nelson S et al. The Beaufort Court energy system-PVT and solar thermal for the preheating of ventilation air. In: ESTEC 2005, Freiburg, 2005.

[61] Zondag HA, Eisenmann W, Borg NJCM vd. PVT performance measurement guidelines - guidelines for performance measurements of liquid-cooled non-concentrating PVT collectors using c-Si cells. Report D8-6 PV-Catapult (see 〈www.pvtforum.org〉), 2005.

[62] Rockendorf G, Sillmann R, Podlowski L, Litzenburger B. PV-hybrid and thermo-electric collectors. Sol Energy 1999;67(4-6):227-37.

[63] Hausler T, Rogass H. Latent heat storage on photovoltaics. In: 16th EPSEC, Glasgow, 2000.

[64] Krauter SCW, Ochs F. An integrated solar home system - history. In: Third WCPEC, Osaka, 2003.

[65] Krauter SCW. Development of an integrated solar home system. SEMS 2004;82:119-30.

[66] Krauter SCW. Enhanced integrated solar home system. In: 19th EPSEC, Paris, 2004.

[67] Krauter SCW. Furher development of the integrated solar home system (I-SHS). In: 20th EPSEC, Barcelona, 2005.

[68] Soerensen B. PV power and heat production: an added value. In: 16th EPSEC, Glasgow, 2000.

[69] Soerensen B. Modelling of hybrid PV-thermal systems. In: 17th EPSEC, Munich, 2001.

[70] Bazilian MD, Groenhout NK, Prasad D. Simplified numerical modelling and simulation of a photovoltaic heat recovery system. In: 17th EPSEC 2001, Munich, 2001. 
[71] Bazilian MD, Groenhout NK, Prasad D. A simple computational fluid dynamics model of a residential cogeneration system. In: 17th EPSEC 2001, Munich, 2001.

[72] Bazilian MD, Leenders F, Van der Ree BCG, Prasad D. Photovoltaic cogeneration in the built environment. Sol Energy 2001;71(1):57-69.

[73] Leenders F, van der Ree BCG, Soerensen H. PV/T road map - from R\&D to market introduction. Northsun Leiden, 2001.

[74] Bazilian MD, Kamalanthan H, Prasad D. Thermographic analysis of a building integrated photovoltaic system. Renew Energy 2002;26:449-61.

[75] Tripanagnostopoulos Y, Nousia Th, Souliotis M. Hybrid PV-ICS systems. In: Fifth WREC, Florence, 1998.

[76] Tripanagnostopoulos Y, Nousia Th, Souliotis M. Test results of air cooled modified PV modules. In: 17th EPSEC, Munich, 2001.

[77] Tripanagnostopoulos Y, Tzavellas D, Zoulia I, Chortatou M. Hybrid PV/T systems with dual heat extraction operation. In: 17th EPSEC, Munich, 2001.

[78] Tripanagnostopoulos Y, Bazilian M, Zoulia I, Battisti R. Hybrid PV/T system with improved air heat extraction modification. In: PV in Europe, Rome, 2002.

[79] Tripanagnostopoulos Y, Nousia Th, Souliotis M, Yianoulis P. Hybrid photovoltaic/thermal solar systems. Sol Energy 2002;72(3):217-34.

[80] Tselepis S, Tripanagnostopoulos Y. Economic analysis of hybrid photovoltaic/thermal solar systems and comparison with standard PV modules. In: PV in Europe, Rome, 2002.

[81] Kalogirou SA. Use of TRNSYS for modelling and simulation of a hybrid PV-thermal solar system for Cyprus. Renew Energy 2001;23:247-60.

[82] Tripanagnostopoulos Y, Kalogirou S. Design aspects and application of hybrid PV/T solar systems. In: Eighth WREC, Denver, 2004.

[83] Bergene T, Løvvik OM. Model calculations on a flat-plate solar heat collector with integrated solar cells. Sol Energy 1995;55(6):453-62.

[84] Meir MG, Rekstad JB, Løvvik OM. A study of a polymer-based radiative cooling system. Sol Energy 2002;73(6):403-17.

[85] Sandnes B, Rekstad J. A photovoltaic/thermal (PV/T) collector with a polymer absorber plate. Experimental study and analytical model. In: ISES Eurosun, Copenhagen, 2000.

[86] Sandnes B, Rekstad J. A photovoltaic/thermal (PV/T) collector with a polymer absorber plate. Experimental study and analytical model. Sol Energy 2002;72(1):63-73.

[87] Elazari A. Multi solar system: solar multimodule for electrical and hot water supply for residentially building. In: 2nd WCPEC, Vienna, Austria; 1998.

[88] Hayakashi B, Muzusaki K, Satoh T, Hatanaka T. Research and development of photovoltaic/thermal hybrid solar power generation system. In: ISES Solar World Congress, Kobe, 1989.

[89] Fujisawa T, Tani T. Binary utilization of solar energy with photovoltaic-thermal hybrid collector. In: ISES Solar World Congress, Korea, 1997.

[90] Ito S, Miura N, Wang K. Performance of a heat pump using direct expansion solar collectors. Sol Energy 1999;65(3):189-96.

[91] Ito S, Matsubayashi T, Miura N. Studies of a heat pump using dual heat sources of solar heat and ambient air. In: Eurosun, Freiburg, 2004.

[92] Nishikawa M, Sone T, Ito S. A heat pump using solar hybrid panels as the evaporator. In: ISES Solar World Congress, Budapest, 1993.

[93] Huang BJ, Lin TH, Hung WC, Sun FS. Solar photo-voltaic/thermal co-generation collector. In: ISES Solar World Congress, Jerusalem, 1999.

[94] Huang BJ, Lin TH, Hung WC, Sun FS. Performance evaluation of solar photovoltaic/thermal systems. Sol Energy 2001;70(5):443-8.

[95] Chow TT. Performance analysis of photovoltaic-thermal collector by explicit dynamic model. Sol Energy 2003;75:143-52.

[96] Ji J, Han J, Chow TT, Han C, Lu J, He W. Effect of flow channel dimensions on the performance of a boxframe photovoltaic/thermal collector. Proc Inst Mech Eng, Part A—J Power Energy 2006;220:681-8.

[97] He W, Chow TT, Ji J, Lu JP, Pei G, Chan L. Hybrid photovoltaic and thermal solar-collector designed for natural circulation of water. Appl Energy 2006;83:199-210.

[98] Agarwal RK, Garg HP. Study of a photovoltaic-thermal system - thermisyphonic solar water heater combined with solar cells. Energy Convers Manage 1994;35(7):605-20. 
[99] Garg HP, Agarwal RK, Joshi JC. Experimental study on a hybrid photovoltaic-thermal solar water heater and its performance predictions. Energy Convers Manage 1994;35(7):621-33.

[100] Garg HP, Agarwal RK. Some aspects of a PV/T collector/forced circulation flat plate solar water haeter with solar cells. Energy Convers Manage 1995;36(2):87-99.

[101] Sadamoto K, Supanich P, Nualboonrueng T, Sichanugrist P. a-Si hybrid solar collector. In: Third WCPEC, Osaka, 2003.

[102] Sadamoto K, Nualboonruen T, Sichanugrist P. The performance of a-Si hybrid solar that uses low iron glass as top-surface of PV module. Asian J Energy Environ 2004;5(2):109-14.

[103] Jaikra S, Nualboonrueng T, Sichanugrist P. Development of PV/T system in Thailand. In: 31st IEEE, Florida, 2005.

[104] Jaikra S, Nualboonrueng T, Sichanugrist P. Amorphous-silicon photovoltaic/thermal solar collector in Thailand. In: 15th PVSEC, Shanghai, 2005.

[105] Lenox C, Ansley J, Torres A. PV BONUS Two: PowerRoof 2000 - final report. Report Powerlight, 2003.

[106] SDA. The hybrid Photovoltaic/thermal collector-final technical report (2004). Report, 2004.

[107] Boer KW, Tamm G. Solar conversion under consideration of energy and entropy. Sol Energy 2003;74:525-8.

[108] Malik MAS. In: Sayigh AAM, editor. Solar one; from solar energy applications in buildings. New York: Academic Press; 1979.

[109] Raghuraman P. Analytical predictions of liquid and air photovoltaic/thermal, flat-plate collector performance. J Sol Energy Eng 1981;103:291-8.

[110] Russell T, Beal J, Loferski JJ, Roessler B, Dobbins R, Shewchun J, et al. Combined photovoltaic/thermal collector panels of improved design. In: 15th IEEE, Kissimmee, 1981.

[111] Smith DR, Biringer KL, Pritchard DA. Combined photovoltaic thermal collector testing. In: 13th IEEE, Washington, 1978.

[112] Loferski JJ, Case C, Doodlesack G, Roessler B, Dobbins R, Russell T et al. Design and construction of a hybrid Photovoltaic $(3 \mathrm{kWp})$-thermal solar energy system for a residential/commercial building. In: 16th IEEE, San Diego, 1982.

[113] Komp R, Reeser T. Design, construction \& operation of a PV/Hot air hybrid energy system. In: ISES Solar World Congress, Hamburg, 1987.

[114] Ito S, Miura N. Solar air collectors using photovoltaic modules as cover. In: ISES Solar World Congress, Budapest, 1993.

[115] Ricaud A, Roubeau P. Capthel', a 66\% efficient hybrid solar module and the 'ecothel' co-generation solar system. In: First WCPEC, Hawaii, 1994.

[116] Hollick JC. Solar cogeneration panels. Renew Energy 1998;15:195-200.

[117] Thomas HP, Hayter SJ, Martin RL, Pierce LK. PV and PV/hybrid products for buildings. In: 16th EPSEC, Glasgow, 2000.

[118] Tonui JK, Tripanagnostopoulos Y. Improved performance PVT/AIR solar systems. In: 20th EPSEC, Barcelona, 2005.

[119] Sopian K, Yigit KS, Liu HY, Kakac S, Veziroglu TN. Performance analysis of photovoltaic thermal air heaters. Energy Convers Manage 1996;37(11):1657-70.

[120] Sopian K, Liu HY, Kakac S. Research and development of hybrid photovoltaic thermal solar air heaters. Int J Global Energy Issues 1997;9(4-6):382-92.

[121] Sopian K, Liu HY, Kakac S, Veziroglu TN. Performance of a double pass photovoltaic thermal solar collector suitable for solar drying systems. Energy Convers Manage 2000;41:353-65.

[122] Othman MYHj, Yatim B, Sopian K, Abu Bakar MN. Performance analysis of a double pass photovoltaic/ thermal (PV/T) solar collector with CPC and fins. Renew Energy 2005;30:2005-17.

[123] Hegazy AA. Comparative study of the performances of four photovoltaic/thermal solar air collectors. Energy Convers Manage 2000;41:861-81.

[124] Bhargava AK, Garg HP, Agarwal RK. Study of a hybrid solar system - solar air heater combined with solar cells. Energy Convers Manage 1991;31(5):471-9.

[125] Garg HP, Agarwal RK, Bhargava AK. The effect of plane booster reflectors on the performance of a solar air heater with solar cells suitable for a solar dryer. Energy Convers Manage 1991;6:543-54.

[126] Garg HP, Adhikari RS. Conventional photovoltaic/thermal (PV/T) air heating collectors: steady state simulation. Renew Energy 1997;11(3):363-85.

[127] Garg HP, Adhikari RS. Transient simulation of conventional hybrid photovoltaic/thermal (PV/T) air heating collectors. Int J Energy Res 1998;22:547-62. 
[128] Garg HP, Adhikari RS. System performance studies on a photovoltaic/thermal (PV/T) air heating collector. Renew Energy 1999;16:725-30.

[129] Tiwari A, Sodha MS. Performance evaluation of solar PV/T system: an experimental validation. Sol Energy 2006;80:751-9.

[130] Tiwari A, Sodha MS. Parametric study of various configurations of hybrid PV/thermal air collector: Experimental validation of theoretical model. Sol Energy Mater Sol Cells 2007;91:17-28.

[131] Posnansky M, Hochreutener H, Gnos S. Building integrated photovoltaic systems: examples of realized PV-roof and PV-facade power plants with specially conceived PV-modules for building integration. In: 11th EPSEC, Montreux, 1992.

[132] Posnansky M, Eckmanns A, Szacsvay T. Cogeneration of electricity and heat on building integrated PV-power-systems: practical results. In: 14th EPSEC, Barcelona, 1997.

[133] Posnansky M, Gnos S, Coonen S. The importance of hybrid PV-building integration. In: First WCPEC, Hawaii, 1994.

[134] Posnansky M, Eckmanns A. Practical results with cogeneration of electricity and heat in building integrated PV power systems. In: 13th EPSEC, Nice, 1995.

[135] Posnansky M, Szacsvay T, Dütsch B, Stucki B. Sunslates ${ }^{\mathrm{TM}}$ - a novel PV-roofing and façade system, key to the large scale utilization of solar energy. In: 14th EPSEC, Barcelona, 1997.

[136] Kropf S. PV/T Schiefer, Optimierung der Energieeffizienz von Gebäuden durch gegenseitige Ergänzung von Simulation und Messung am Beispiel der Hinterlüftung gebäudeintegrierter Photovoltaik. PhD report, ETH Zurich, 2003.

[137] Kropf S, Moser A, Zweifel G. Useful waste heat of ventilated PV-modules: physical modelling and validation results. In: Eighth IBPSA, Eindhoven, 2003.

[138] Pedersen PV. Cost-effective building integrated PV-systems with combined electricity and heat production. In: ISES Eurosun, Copenhagen, 2000.

[139] Jensen SO. Results from measurements on the PV-VENT systems at Lundebjerg. Report DTI, 2001.

[140] Jensen SO. Results from measurements on the PV-VENT systems at Sundevedsgade/Toendergade. Report DTI, 2001.

[141] Rasmussen A, Abate C, Jol JC. Technical report no. 4: InnoPex-innovative architectural integration of photovoltaic energy in existing buildings in DK, NL, IT. Report, Cenergia, 2001.

[142] Joergensen OB, Nielsen LT. Monitored results from the Yellow House. In: ISES Eurosun, Copenhagen, 2000.

[143] Bates JR, Pearsall NM, Crick F, Wilshaw AR, Baker P. The performance of photovoltaic modules incorporated into a prototype ventilated façade. In: ISES Eurosun, Freiburg, 1996.

[144] Crick FJ, McNelis B, Wilshaw A, Shaw M, Parr A, Laukamp H et al. PV cladding prototypes for commercial buildings in Europe - development, construction and testing. In: 13th EPSEC, Nice, 1995.

[145] Crick FJ, Raftery P, McNelis B, Shaw M, Parr A, Laukamp H, et al. PV cladding prototypes for commercial buildings in Europe - development construction and testing - the final phase. In: ISES Eurosun, Freiburg, 1996.

[146] Crick FJ, Wilshaw A, Pearsall NM, Hynes K, Shaw M, Young G et al. Photovoltaic ventilated facade: system investigation and characterization. In: 14th EPSEC, Barcelona, 1997.

[147] Shaw M, Scott R, Noble R, Crick FJ, Raftery P, Parr AE et al. The concept of the photovoltaic ventilated façade. In: 13th EPSEC, Nice, 1995.

[148] Ossenbrink HA, Rigolini L, Chehab O, Van der Venne O. Building integration of an amorphous silicon photovoltaic façade. In: First WCPEC, Hawaii, 1994.

[149] Bloem JJ, Ossenbrink HA. Thermal aspects of PV integration in buildings. In: 13th EPSEC, Nice, 1995.

[150] Clarke JA, Johnstone C, Strachan P, Bloem JJ, Ossenbrink HA. Thermal and power modelling of the photovoltaic facade of the ELSA building, Ispra. In: 13th EPSEC, Nice, 1995.

[151] Mosfegh B, Sandberg M, Bloem JJ, Ossenbrink HA. Analysis of fluid flow and heat transfer within the photovoltaic facade of the ELSA building, JRC Ispra. In: 13th EPSEC, Nice, 1995.

[152] Mosfegh B, Sandberg M. Investigation of fluid flow and heat transfer in a vertical channel heated from one side by PV elements part I—numerical study. In: Fourth WREC, Denver, USA, 1996.

[153] Mosfegh B, Sandberg M. Flow and heat transfer in the air gap behind photovoltaic panels. Renew Sustain Energy Rev 1998;2:287-301.

[154] Sandberg M, Mosfegh, B. Investigation of fluid flow and heat transfer in a vertical channel heated from one side by PV elements part II—experimental study. In: Fourth WREC, Denver, USA, 1996. 
[155] Clarke JA Appraising the performance of building-integrated photovoltaic systems. In: 14th EPSEC, Barcelona, 1997.

[156] Clarke JA, Johnstone C, Kelly N, Strachan PA. The simulation of photovoltaic-integrated building facades. IBPSA; 1997.

[157] Hahne E, Pfluger R. Overall performance evaluation of hybrid photovoltaic building components. In: ISES Solar World Congress, Korea, 1997.

[158] Strachan PA, Johnstone CM, Kelly N, Bloem JJ, Ossenbrink HA. Results of thermal and power modelling of the PV facade on the ELSA building, Ispra. In: 14th EPSEC, Barcelona, 1997.

[159] Vandaele L, Wouters P, Bloem JJ. Hybrid photovoltaic building components: overall performance assessment by testing and simulation. In: 14th EPSEC, Barcelona, 1997.

[160] Vandaele L, Wouters P, Bloem JJ, Zaaiman WJ. Combined heat and power from hybrid photovoltaic building integrated components: results from overall performance assessment. In: Second WCPEC, Vienna, 1998.

[161] Versluis R, Bloem JJ, Dunlop ED. An energy model for hybrid photovoltaic building facades. In: 14th EPSEC, Barcelona, 1997.

[162] Versluis R, Van Dijk HAL. PV-HYBRID-PAS Results of thermal performance assessment. In: Second WCPEC, Vienna, 1998.

[163] Virtanen M, Heimonen I, Pfluger R. Ventilation behaviour of hybrid PV building components. In: 14th EPSEC, Barcelona, 1997.

[164] Wouters P, Demeester J, Martin S, Vandaele L. Market potential for industrial hybrid photovoltaic applications in buildings. In: 14th EPSEC, Barcelona, 1997.

[165] Dunlop ED, Haverkamp E, Sandberg M, Strobach JM. The energy balance of roof integrated hybrid photovoltaic modules. In: Second WCPEC, Vienna, 1998.

[166] Sandberg M, Strobach JM, Dunlop ED. Aspects of air and heat flow for roof integrated PV Hybrid systems. In: Second WCPEC Vienna, 1998.

[167] Sandberg M, Mosfegh B. Ventilated-solar roof airflow and heat transfer investigation. Renew Energy 1998;15(1):287-92.

[168] Strobach JM, Sandberg M, Dunlop ED. Specific module design for realistic working conditions. In: Second WCPEC, Vienna, 1998.

[169] Brinkworth BJ, Cross BM, Marshall RH, Hongxing Y. Thermal regulation of photovoltaic cladding. Sol Energy 1997;61(3):169-78.

[170] Brinkworth BJ. Estimation of flow and heat transfer for the design of PV cooling ducts. Sol Energy 2000;69(5):413-20.

[171] Brinkworth BJ, Marshall RH, Ibarahim Z. A validated model of naturally ventilated PV cladding. Sol Energy 2000;69(1):67-81.

[172] Yang HX, Marshall RH, Brinkworth BJ. An experimental study of the thermal regulation of a PV-clad building roof. In: 12th EPSEC, Amsterdam, 1994.

[173] Yang HX, Marshall RH, Brinkworth BJ. Validated simulation for thermal regulation of photovoltaic wall structures. In: 25th PVSC, Washington, 1996.

[174] Brinkworth BJ, Sandberg M. Design procedure for cooling ducts to minimise efficiency loss due to temperature rise in PV arrays. Sol Energy 2006;80:89-103.

[175] Sandberg M, Mosfegh B. Buoyancy-induced airflow in photovoltaic facades - effect of geometry of the air gap and location of solar cell modules. Building Environ 2002;37:211-8.

[176] Hacker RJ, Bates JR, Blieske U, Bloem JJ, Campbell J, Ferrazza F, Strachan PA, Tripanagnostopoulos Y. Building implementation of photovoltaics with active control of temperature, 'Building Impact'-final results. In: 17th EPSEC 2001, Munich, 2001.

[177] Taylor CM, Bates JR, Bloem JJ, Bucci C, Campbell J, Luling N, Tripanagnostopoulos Y, Ruyssevert PA. Building implementation of photovoltaics with active control of temperature - 'Building Impact'. In: 16th EPSEC, Glasgow, 2000.

[178] Tripanagnostopoulos Y, Nousia Th, Souliotis M. Low cost improvement to building integrated air cooled hybrid PV-thermal systems. In: 16th EPSEC, Glasgow, 2000.

[179] Chantant M, Servant JM, Ragot Ph, Aguillon JC, Girard M, Lloret A et al. Design computations and performance assesment of multifunctional modules. In: 13th EPSEC, Nice, 1995.

[180] Eicker U, Gross M. PV curtain walls for air preheating. In: 14th EPSEC, Barcelona, 1997.

[181] Lloret A, Andreu J, Merten J, Aceves O, Sabata L, Sen F, Puigdollers J, Person C, Chantant M, Servant JM, Eicker U. The Mataro public library: a $53 \mathrm{kWp}$ grid connected building with integrated PV-Thermal multifunctional modules. In: 13th EPSEC, Nice, 1995. 
[182] Lloret A, Aceves O, Andreu J, Merten J, Puigdollers J, Chantant M et al. Lessons learned in the electrical system design, installation and operation of the Mataro public library. In: 14th EPSEC, Barcelona, 1997.

[183] Eicker U, Hoefker G, Seeberger P, Fux V, Vollmer K. Building integration of PV and solar air heaters for optimised heat and electricity production. In: Second WCPEC, Vienna, 1998.

[184] Eicker U, Fux V, Infield D, Mei L, Vollmer K. Thermal performance of building integrated ventilated PV facades. In: ISES Solar World Congress, Jerusalem, 1999.

[185] Eicker U, Fux V, Infield D, Mei L. Heating and cooling potential of combined photovoltaic-solar air collector facades. In: 16th EPSEC, Glasgow, 2000.

[186] Infield D, Mei L, Eicker U, Fux V. Understanding the potential of ventilated PV facades. In: ISES Solar World Congress, Jerusalem, 1999.

[187] Infield D, Mei L, Eicker U, Fux V. Parameter estimation for ventilated PV facades. In: 16th EPSEC, Glasgow, 2000.

[188] Infield D, Mei L, Eicker U. Thermal performance estimation for ventilated PV facades. Sol Energy 2004;76:93-8.

[189] Infield D, Mei L, Lee WM, Loveday DL. Thermal aspects of building integrated PV systems. In: Third WCPEC, Osaka, 2003.

[190] Mei L, Infield D, Eicker U, Fux V. Thermal modelling for building integrated ventilated PV façade. In: CIBSE conference, UK, 2001.

[191] Mei L, Infield D, Eicker U, Fux V. Thermal modelling of a building with an integrated ventilated façade. Energy Buildings 2003;35:605-17.

[192] Eicker U. Adsorption cooling of buildings with integrated PV/solar air heating facades-AIRCOOL. Final report for project ERK6-CT1999-00010, 2002.

[193] Eicker U, Huber M, Schürger U, Schumacher J, Trinkle A. Desiccant cooling technology powered by solar thermal air collector systems. In: ISES Solar World Congress, Göteborg, 2003.

[194] Fitzpatrick S. Performance of a building integrated PV/Thermal system on a bank in North Carolina $\langle$ http://www.ncsc.ncsu.edu/research/documents/technical_papers/Perform_BIPV.pdf $\rangle, 1999$.

[195] Stevens R, Fitzpatrick S. North Carolina Solar Center Initiatives Explore Energy Alternatives, 〈http:// www.engr.ncsu.edu/news/news_articles/solar.center.html $>, 2001$.

[196] Cartmell BP, Shankland NJ, Fiala D, Hanby V. A multi-operational ventilated photovoltaic and solar air collector: application, simulation and initial monitoring feedback. In: ISES Solar World Congress, Adelaide, 2001.

[197] Cartmell BP, Shankland NJ, Fiala D, Hanby V. A multi-operational ventilated photovoltaic and solar air collector: application, simulation and initial monitoring feedback. Sol Energy 2004;76:45-53.

[198] Baker PH, Porteous CDA, Sharpe TR. Hybrid dynamic insulation wall in Scotland: early test results. Leiden: Northsun; 2001.

[199] Kondratenko IV, Porteous CDA. Hybrid BIPV as environmental problem-solver-Glasgow case study. In: ISES Eurosun, Copenhagen, 2000.

[200] Kondratenko IV, Porteous CDA. Double skin solar facade component with Building-integrated photovoltaics (BIPV) as electrical, thermal and daylighting optimizer. Northsun, 2001.

[201] Kondratenko IV. Urban retrofit building integrated photovoltaics [BIPV] in Schotland, with particular reference to double skin facades. PhD thesis, University of Glasgow, 2003.

[202] Porteous CDA, Sharpe TR, Baker PH. Experimental hybrid PV dynamic insulation wall in Scotland. In: ISES Eurosun, Copenhagen, 2000.

[203] Aste N, Beccali M, Solaini G. Experimental validation of a simulation model for a PV/T collector. In: ISES Solar World Congress, Göteborg, 2003.

[204] Adhikari RS, Butera F, Oliaro P, Caputo P. Optimisation of solar-assisted desiccant cooling and control system. In: Eighth WREC, Denver, 2004.

[205] Butera F, Aste N, Adhikari RS, Bracco R. Ecomensa Project at CRF: performance of solar façade. In: 600 Congresso Nazionale ATI, Rome, 2005.

[206] Campanile P, Parodi ML, Menardi L, Mola S, Bracco R. Efficient integration of solar energy, trigeneration and desiccant cooling: the 'ECO-canteen' of CRF. In: DAME-BC Warshaw workshop, 2004.

[207] Corredera G, Dalibart C, Cayre E, Kherrouf, S. Energetic and economical evaluation of a photovoltaic/ thermal collector in a collective housing - competition with other sustainable solutions. In: ISES Solar World Congress, Göteborg, 2003.

[208] Guiavarch A, Peuportier B. Improving the environmental balance of building integrated photovoltaic systems. In: ISES Solar World Congress, Göteborg, 2003. 
[209] Guiavarch A, Peuportier B. Photovoltaic collectors efficiency according to their integration in buildings. Sol Energy 2006;80(1):65-77.

[210] Bazilian MD, Prasad D. A holistic approach to photovoltaic/thermal/daylight (PV/T/L) cogeneration. In: ISES Eurosun, Copenhagen, 2000.

[211] Bazilian MD, Prasad D. Thermal and electrical performance monitoring of a combined BIPV array and modular heat recovery system. In: ISES Solar World Congress Adelaide, Australia, 2001.

[212] Bazilian MD. Australia's first BiPV/thermal test facility (an ACRE funded research project). In: PV in Europe, Rome, 2002.

[213] Bazilian MD, Prasad D. Modelling of a photovoltaic heat recovery system and its role in a design decision support tool for building professionals. Renew Energy 2002;27:57-68.

[214] Ji J, Wei H, Lam HN. The annual analysis of the power output and heat gain of a PV-wall with different integration mode in Hong Kong. SEMS 2002;71:435-48.

[215] Ji J, Chow TT, He W. Dynamic performance of hybrid photovoltaic/thermal collector wall in Hong Kong. Building Environ 2003;38:1327-34.

[216] Takashima T, Tanaka T, Doi T, Kamoshida J. New proposal for photovoltaic-thermal solar energy utilization method. Sol Energy 1994;52(3):241-5.

[217] Nagano K, Mochida T, Shimakura K, Murashita M. Performance of hybrid wallboards united with PV cells. In: ISES Solar World Congress, Adelaide, 2001.

[218] Nagano K, Mochida T, Shimakura K, Murashita M, Takeda S. Development of thermal-photovoltaic hybrid exterior wallboards incorporating PV cells in and their winter performances. SEMS 2003;77:265-82.

[219] Komp R. Practical photovoltaics - electricity from solar cells, 3rd ed. revised. Ann Arbor: Aatec Publications; 2002.

[220] Affolter P, Gay JB, Haller A, Althaus HJ, Ruoss D, Toggweiler P. A new generation of hybrid solar collectors. In: 14th EPSEC, Barcelona, 1997.

[221] Furbo S, Jivan Shah L. Thermal advantages for solar heating systems with a glass cover with antireflection surfaces. Sol Energy 2003;74:513-23.

[222] Furbo S, Jivan Shah L, Overvad Jensen L, Larsen E, Olsson G. Advantages by utilizing antireflection treated glass covers for PV modules. In: ISES Eurosun, Freiburg, 2004.

[223] Peuser FA, Remmers KH, Schnauss M. Solar thermal systems. Berlin: Solarpraxis; 2002.

[224] Köhl M, Jorgensen G, Brunold S, Carlsson B, Heck M, Möller K. Durability of polymeric glazing materials for solar applications. Sol Energy 2005;79:618-23.

[225] Raman R, Mantell S, Davidson J, Wu C, Jorgensen G. A review of polymer materials for solar water heating systems. J Sol Energy Eng 2000;122:92-100.

[226] Santbergen R, van Zolingen RJC. An optical model for the absorption factor of textured crystalline silicon PV cells. In: 21st EPSEC, Dresden, 2006.

[227] Santbergen R, Van Zolingen RJC. Modelling the thermal absorption factor of photovoltaic/thermal combipanels. Grenoble: Heat SET; 2005.

[228] Affolter P, Haller A, Ruoss D, Toggweiler P. A new generation of hybrid solar collectors-Absorption and high temperature behaviour evaluation of amorphous modules. 16th EPSEC Glasgow, 2000.

[229] Platz R, Fischer D, Zufferey MA, Anna Selvan JA, Haller A, Shah A. Hybrid collectors using thin-film technology. In: 26th PVSC Anaheim, CA, 1997.

[230] Sudhakar SV, Sharon M. Fabrication and performance evaluation of a photovoltaic/thermal hybrid system. SESI J 1994;4(1):1-7.

[231] Gibbons CJ, Murphy D. Determination of the influence of encapsulation methods on the magnitude of thermal interfacial resistances in photovoltaic modules. In: ISES Eurosun, Freiburg, 2004.

[232] Van der Vleuten P. Thin film silicon solar cells on insulated metal surfaces. In: 19th EPSEC, Paris, 2004.

[233] Chow TT, He W, Ji J. Hybrid photovoltaic-thermosyphon water heating system for residential application. Sol Energy 2006;80(3):298-306.

[234] Ji J, Lu JP, Chow TT, He W, Pei G. A sensitivity study of a hybrid photovoltaic/thermal water-heating system with natural circulation. Appl Energy 2007;84:222-37.

[235] Prakash J. Transient analysis of a photovoltaic-thermal solar collector for co-generation of electricity and hot air/water. Energy Convers Manage 1994;35(11):967-72.

[236] Eicker U. Solar technologies for buildings. New York: Wiley; 2003.

[237] Bansal NK, Sharma VK. In: Garg G, editor. Glazing materials for solar collectors, in solar water heating systems. Dordrecht: Reidel Publishing; 1985.

[238] Gordon J. Solar energy the state of the art-ISES position papers. London: James \& James; 2001. 
[239] Hof C, Lüdi M, Goetz M, Fischer D, Shah A. Long term behaviour of passively heated or cooled a-Si:H modules. In: 25th IEEE, Washington, 1996.

[240] Naveed AT, Kang EC, Lee EJ. Effect of unglazed transpired collector on the performance of a polycrystalline silicon photovoltaic module. J. Sol Energy Eng 2006;128:349-53.

[241] Lambarski TJ. Electrical design guidelines for photovoltaic/thermal systems. In: 17th IEEE, Kissimmee, 1984.

[242] Davidson J, Komp R. The solar electric home. Ann Arbor: Aatec Publications; 1983.

[243] Bollo C, Pappalardo A, Marletta G. PV powered solar ventilation system for buildings. In: 13th EPSEC, Nice, 1995.

[244] Infield D. Design, study and experimental evaluation of an integrated solar façade. Final report for project JOR3-CT97-0185, 2000.

[245] Wouters P, Vandaele L, editors. PV-Hybrid-PAS Development of procedures for overall performance evaluation of hybrid photovoltaic building components - final report. Report, 1998.

[246] Martin S, Wouters P, l'Heureux D. Detailed technical report on BBRI heating foil experiments. PV-HybridPAS annex report 4, 1998.

[247] Infield D, Mei L, Rowley P, Eicker U. Performance estimation for ventilated PV facades. In: ISES Solar World Congress, 2001.

[248] Gandini A, Mazzarella L, Bloem JJ. Numerical analysis of PV double skin facades. DAME-BC, Ispra, 2003.

[249] Tonui JK, Tripanagnostopoulos Y. Improved PV/T solar collectors with heat extraction by forced or natural air circulation. Renew Energy 2006;32:623-37.

[250] Kelly NJ, Strachan PA. Modelling enhanced performance of building integrated PV modules. In: 16th EPSEC Glasgow, 2000.

[251] Hodge E, Gibbons C. Convective cooling of photovoltaics. In: ISES Eurosun, Freiburg, 2004.

[252] Chow TT, Hand JW, Strachan PA. Building-integrated photovoltaic and thermal applications in a subtropical hotel building. Appl Thermal Eng 2003;23:2035-49.

[253] Ito S, Miura N, Wang K. Heat pump using a solar collector with photovoltaic modules on the surface. JSEE 1997;119:147-51.

[254] Hastings SR, Mørck O. Solar air systems, a design handbook. London: James \& James; 2000.

[255] Hastings SR, Mørck O. Solar air systems, built examples. London: James \& James; 1999.

[256] Aceves O, Llorach E, Barbat E, Genard P, Hentschel D, Ori A et al. $1000 \mathrm{~m}^{2}$ of hybrid PV-thermal ventilated semi-transparent roof in a TV studios Imagina Visual Center (Esplugues-Barcelona). In: 20th EPSEC, Barcelona, 2005.

[257] Battisti R, Tripanagnostopoulos Y. PV/Thermal systems for application in industry. In: 20th EPSEC, Barcelona, 2005.

[258] ESTIF. Sun in Action II-a solar thermal strategy for Europe, 2003.

[259] Weiss W, Bergmann I, Faninger G. Solar heat worldwide - markets and contribution to the energy supply 2004. SHC report, 2006.

[260] Adhikari RS, Butera F, Caputo P, Oliaro P, Aste N. Thermal and electrical performances of a new kind air cooled photovoltaic thermal system for building application. In: ISES Solar World Congress, Göteborg, 2003.

[261] Aste N, Beccali M, Chiesa G. Experimental evaluation of the performance of a prototype hybrid solar photovoltaic-thermal (PV/T) air collector for the integration in sloped roof. Lyon: EPIC; 2002.

[262] Bloem JJ, Zaaiman W, Van Dijk D. Electric and thermal performance assesment of hybrid photovoltaic systems using the paslink test facility. In: 14th EPSEC, Barcelona, 1997.

[264] Cross BM. Development, testing and first installations of an integrated solar roof system. In: First WCPEC, Hawaii, 1994.

[268] Ibarahim Z, Marshall R, Spratt M. Simplified loop analysis for a naturally ventilated channel heated from one side by PV elements. In: Second WCPEC, Vienna, 1998.

[269] Imre L, Bitai A, Bohonyey F, Hecker G, Palfy M. PV-thermal combined building elements. In: ISES Solar World Congress, Budapest, 1993.

[271] Jong MJM. System studies on combined PV/Thermal panels. In: 11th symposium thermische solarenergie, Staffelstein, 2001.

[273] Krauter S, Araujo G, Schroer S, Hanitsch R, Salhi MJ, Triebel C, et al. Combined photovoltaic and solar thermal systems for façade integration and building insulation. Sol Energy 1999;67(4-6):239-48.

[274] Krauter S, Araujo G, Schroer S, Salhi MJ, Triebel C, Lemoine R, et al. Combined photovoltaic and solar thermal systems for façade integration and building insulation. In: ISES Solar World Congress, Jerusalem, 1999. 
[275] Krauter S, Salhi MJ, Schroer S, Hanitsch R. New façade system consisting of combined photovoltaic and solar thermal generators with building insulation. In: Seventh IBPSA, Rio de Janeiro, Brazil, 2001.

[276] Lloret A, Andreu J, Merten J, Puigdollers J, Aceves O, Sabata L, et al. Large grid-connected hybrid PV system integrated in a public building. PIP 1998;6:453-64.

[278] Mattei M, Cristofari C, Louche A. Modelling a hybrid PV/T collector. In: Second WCPEC, Vienna, 1998.

[280] New generation of hybrid solar PV/T collectors - feasibility study (phase 1). Report DIS 56360/16868, 1997.

[281] New generation of hybrid solar PV/T collectors. Report DIS 56360/16868, 2000.

[282] Spectrum - der photovoltaik-hybrid-kollektor. product leaflet, 1998.

[284] Tripanagnostopoulos Y, Souliotis M, Battisti R, Corrado A. Application aspects of hybrid PV/T solar systems. In: ISES Solar World Congress, Göteborg, 2003.

[285] Van Helden WGJ, Van Zolingen RJC, Zondag HA. PV thermal systems: PV panels supplying renewable electricity and heat. PIP 2004;12:415-26.

[286] Buffet Ph. Hybrid thermal and photovoltaic concentration collector. EC Contractors meeting, Brussels, 1982.

[288] Gibart C. Study of and tests on a hybrid photovoltaic-thermal collector using concentrated sunlight. Sol Cells 1981;4:71-89.

[289] Nakata Y, Kobe T, Shibuya N, Machida T, Takemoto T, Tsuji T. A $30 \mathrm{kWp}$ concentrating photovoltaic/ thermal hybrid system application. IEEE PSC, San Diego, 1982.

[290] Pfluger R, Twerdy C. Development of procedures for overall performance evaluation of hybrid photovoltaic building components. PV-Hybrid-PAS test report 2, 1998.

[291] Rommel M. Medium temperature collector developments and collector testing. Publication Lisbon Industry workshop, IEA task 33, 2006.

[292] Bazilian MD. Building integrated residential photovoltaic cogeneration. PhD Thesis, UNSW, 2002.

[293] Helmke C, Jantsch M, Ossenbrink HA. The large amorphous silicon PV facade in Ispra-experience and results after one year of operation. In: 13th EPSEC 1995, Nice.

[294] Kalogirou S, Tripanagnostopoulos Y. Performance of a hybrid PV/T thermosyphon system. WREC 2005, Aberdeen.

[295] Tripanagnostopoulos Y, Souliotis M, Battisti R. Corrado A. Performance, cost and life-cycle assessment study of hybrid PVT/air solar systems. PIP 2006;14:65-76.

[296] Martin S, Wouters P, l'Heureux D. Detailed technical report on BBRI hybrid PV-tile roof experiments. PV-Hybrid-PAS annex report 4, 1998.

[297] Mei L, Infield D, Eicker U, Loveday D, Fux V. Cooling potential of ventilated PV facade and solar air heaters combined with a desiccant cooling machine, Renew Energy 2006;31:1265-78. 